GROUND-WATER MOVEMENT AND EFFECTS OF COAL STRIP MINING ON WATER QUALITY OF HIGH-WALL LAKES AND AQUIFERS IN THE MACON-HUNTSVILLE AREA, NORTH-CENTRAL MISSOURI

By Dennis C. Hall and Robert E. Davis

U.S. GEOLOGICAL SURVEY

Water-Resources Investigations Report 85-4102

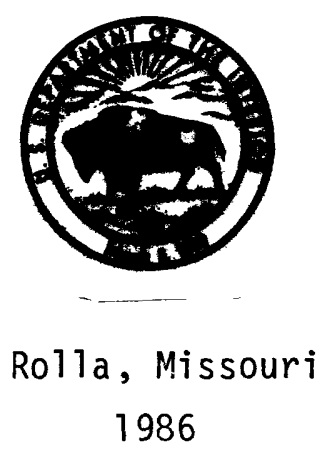




\author{
UNITED STATES DEPARTMENT OF THE INTERIOR \\ Donald Paul Hodel, Secretary \\ GEOLOGICAL SURVEY \\ Dallas L. Peck, Director
}

For additional information write to:

District Chief

U.S. Geological Survey

1400 Independence Road

Mail Stop 200

Rolla, Missouri 65401
Copies of this report can be purchased from:

Open-File Services Section Western Distribution Branch Box 25425, Federal Center Denver, Colorado 80225 Telephone: (303) 236-7476 
Abstract-1-1-1 1

Introduction--1-1 2

Purpose and scope--1-1-1 2

Previous investigations-1-1 7

Physiography and drainage-1-1.-1 7

Climate--1-1-1-1 7

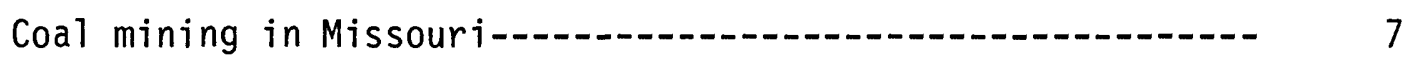

Acknowledgments-1 9

Geology--1-1-1- 9

Stratigraphy-1- 9

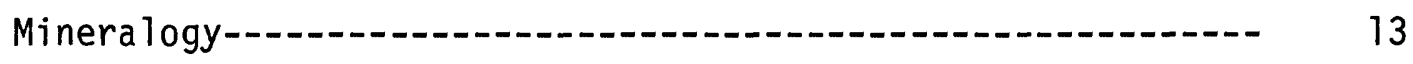

Ground-water movement--13

Transmissivity-13

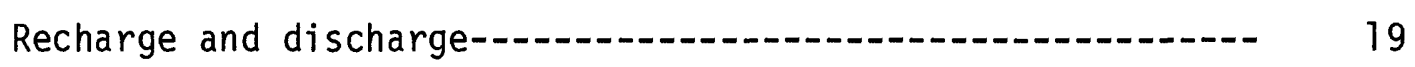

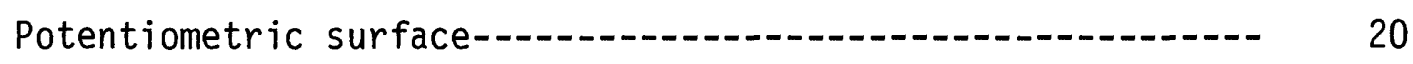

General geochemical processes affecting ground-water quality----- 27

Effects of strip mining on water quality of high-wall lakes and aquifers-- 28

Summary--1-10-10 60

References--1.-- 62

Supplemental data--10.-- 64 


\section{ILLUSTRATIONS}

Figures 1.-4. Maps showing:

1. Location of study area, spoil areas, and wells outside of spoil areas-a.-.

2. Location of observation we1ls, lake staff gages, and miscellaneous lakes in 1940 spoil-.................-

3. Location of observation wells, lake staff gages, and miscellaneous lakes in 1952 spoil--.-.--.-.-.-.--

4. Location of observation wells, lake staff gages, and miscellaneous lakes in 1968 spoil-......

Figure 5. Graph showing precipitation at Macon, May 1981 through December 1983-_ 8

6. Generalized lithologic section through an abandoned strip mine--.-.--

7. Generalized stratigraphy of study area-...............

8. Map showing Pennsylvanian bedrock in the study area-.-... 12

9. Map showing potentiometric surface in shallow aquifers in parts of Macon, Randolph, and Chariton

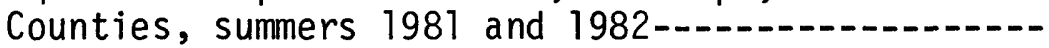

10. Map showing potentiometric surface of shallow aquifers in 1940 spoil, summer 1983

11. Map showing potentiometric surface of shallow aquifers in 1952 and 1968 spoil, summer 1983-.....

Figures 12.-14. Graphs showing:

12. Altitude of water surfaces in wells and lakes in 1940 spoil, May 1981 through December 1983---------

13. Altitude of water surfaces in wells and lakes in 1952 spoil, May 1981 through December 1983-------- 25

14. Altitude of water surfaces in wells and lakes in 1968 spoil, May 1981 through December 1983--.--.--- 26 


\section{ILLUSTRATIONS--Continued}

Page

Figure 15. Diagram of major ions in water from 14 wells (55 analyses) completed in or near spoil and 3

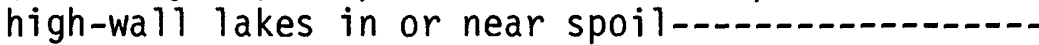

16. Diagram of major ions in water from 4 wells completed in bedrock, 18 wells completed in glacial drift, and 1 lake in glacial drift, not

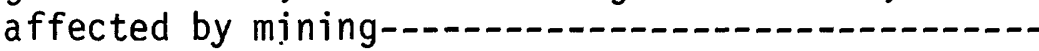

Figures 17.-19. Graphs showing:

17. Ranges and medians of water levels, pH, and selected chemical constituents in water from three wells completed in 1940 spoil-.....-.--

18. Ranges and medians of water levels, pH, and selected chemical constituents in water from four wells completed in 1952 spoil-.......-.

19. Ranges and medians of water levels, pH, and selected chemical constituents in water from three wells completed in 1968 spoil-........- 
Table 1. Sand-silt-clay grain-size distribution in glacial drift and spoil-_......... 14

2. Percentage of calcite and dolomite by weight in glacial

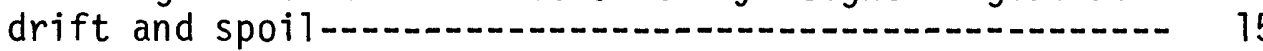

3. Minerals selected for geochemical modeling-_............. 16

4. Reported transmissivities of alluvium, glacial drift, spoil, and bedrock in the Macon, Randolph, and

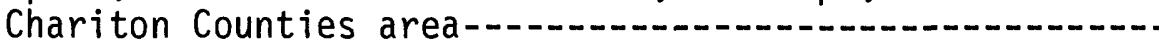

5. Average chemical composition of precipitation at Ashland, December 1981 to Apri1 1982-....

6. Summary of selected properties and concentrations of chemical constituents in water from three high-wall

lakes-_-_-

7. Summary of selected properties and concentrations of chemical constituents in water from nonstrip-mine

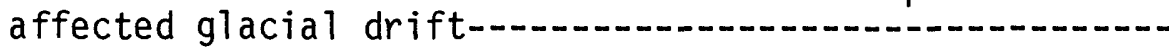

8. Sumary of selected properties and concentrations of chemical constituents in water from bedrock-................

9. Summary of selected properties and concentrations of chemical constituents in water from in or near spoil-1-1

10. Comparison of medians of properties and selected chemical constituents in precipitation, high-wall-lake water, and well water from glacial drift, bedrock, and in or near spoil--_-

11. Comparison of means of property or constituent concentration in water from spoil of different a ges -

12. Oxidation potential (Eh) values used in chemical-

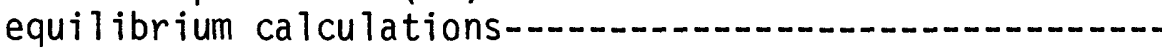

13. Summary of saturation states in water from precipitation, high-wall lakes, and wells completed in glacial drift,

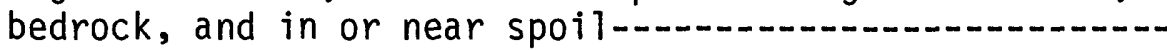

14. Results of mass-balance calculations for chemical changes resulting from selected initial sources to spoil using pyrite as the parent-material source of sulfate-1 pyriten 
Table 15. Results of mass-balance calculations for chemical changes resulting from selected initial sources to spoil using gypsum as the parent-material source of sulfate-_.....

16. Selected data pertaining to wells for which qualityof-water data were obtained-......................... 65

17. Water-quality analys is data for wells and lakes-_._._- 68

18. Reported chemical compositions of water from wells not affected by strip mining-_ 80

19. Surface altitudes of and selected quality-of-water

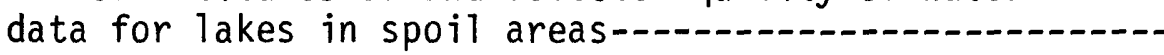

20. Summary of selected properties and concentrations of chemical constituents in water from 1940 spoi

21. Summary of selected properties and concentrations of chemical constituents in water from 1952 spoil-......

22. Summary of selected properties and concentrations of chemical constituents in water from 1968 spoil-_...-.-

23. Saturation indices of selected minerals in water from

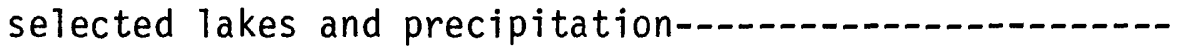

24. Saturation indices of selected minerals in water from wells completed in glacial drift and bedrock not

affected by strip mines-...

25. Saturation indices of selected minerals in water from wells completed in or near spoil-_... 
For readers who prefer to use metric units, conversion factors for terms used in this report are listed below:

$\begin{array}{lll}\text { Multiply inch-pound unit } & \text { By } & \text { To obtain metric unit } \\ \text { inch } & \begin{array}{c}25.40 \\ 0.02540\end{array} & \begin{array}{l}\text { millimeter } \\ \text { meter }\end{array} \\ \text { inch per hour } & 0.007056 & \text { millimeter per second } \\ \text { foot } & 0.3048 & \text { meter } \\ \text { foot per mile } & 0.1894 & \text { meter per kilometer } \\ \text { mile } & 1.609 & \text { kilometer } \\ \text { square mile } & 2.590 & \text { square kilometer } \\ \text { foot squared per day } & 0.09290 & \text { meter squared per day } \\ \text { gallon } & 3.785 & \text { liter or cubic decimeter } \\ \text { cubic meter }\end{array}$

Temperature in degree Celsius $\left({ }^{\circ} \mathrm{C}\right)$ may be converted to degree Fahrenheit $\left({ }^{\circ} \mathrm{F}\right)$ as follows: $F=9 / 5{ }^{\circ} \mathrm{C}+32$.

Temperature in degree Fahrenheit $\left({ }^{\circ} \mathrm{F}\right)$ may be converted to degree Celsius $\left({ }^{\circ} \mathrm{C}\right)$ as follows: ${ }^{\circ} \mathrm{C}=5 / 9\left({ }^{\circ} \mathrm{F}-32\right)$. 


\title{
GROUND-WATER MOVEMENT AND EFFECTS OF COAL STRIP MINING ON WATER QUALITY \\ OF HIGH-WALL LAKES AND AQUIFERS IN THE MACON-HUNTSVILLE AREA, \\ NORTH-CENTRAL MISSOURI
}

By Dennis C. Hall and Robert E. Davis

\begin{abstract}
Glacial drift and Pennsylvanian bedrock were mixed together forming spoil during prereclamation strip mining for coal in north-central Missouri. This restructuring of the land increases the porosity of the material, and increases aqueous concentrations of many dissolved constituents. Median sodium and bicarbonate concentrations were slightly greater, calcium 5 times greater, magnesium 6 times greater, manganese 15 times greater, iron 19 times greater, and sulfate 24 times greater in water from spoil than in water from glacial drift. Median potassium concentrations were slightly greater, and chloride concentrations were two times greater in water from glacial drift than in water from spoil. Water types in glacial drift and bedrock were mostly sodium bicarbonate and calcium bicarbonate; in spoil and lakes in the spoil, the water types were mostly calcium sulfate. Median $\mathrm{pH}$ values in water from spoil were 6.6, as compared to 7.4 in water from glacial drift and 9.0 in water from bedrock. Neutralization of acid by carbonate rocks causes the moderate $\mathrm{pH}$ values in water from spoil; a carbonate system closed to the atmosphere may result in alkaline $\mathrm{pH}$ values in bedrock.
\end{abstract}

Alluvium, glacial drift, bedrock, and spoil are aquifers in the study area. Transmissivities generally are greatest for spoil, and decrease in the following order: alluvium, glacial drift, and bedrock.

Recharge to spoil is from precipitation, lateral flow from glacial drift, and lateral and vertical flow from bedrock. Precipitation probably is the major source of recharge, both directly by infiltration and indirectly as inflow from lakes. The rate of recharge to the aquifers is unknown, but probably is small. Ground-water discharge from the glacial drift, bedrock, and spoil is to alluvium, which generally discharges to streams.

The potentiometric surface in the shallow aquifers generally conformed to the topography. The direction of flow generally was from high-wall lakes in the spoil toward East Fork Little Chariton River or South Fork Claybank Creek.

Significant differences (95-percent confidence level) in values and concentrations of aqueous constituents between spoil areas mined at different times (1940, 1952, and 1968) were obtained for pH, calcium, magnesium, manganese, sulfate, chloride, and dissolved solids, but not for iron. These differences are attributed to local variations in the geohydrologic system rather than spoil age. The changes in water quality occurred in fewer than 12 years and have persisted for more than 40 years. 
Water from high-wall lakes, glacial drift, bedrock, and spoil was saturated with respect to calcite, dolomite, and quartz, but only water from spoil was saturated with respect to gypsum. The difference can be at tributed either to dissolution of freshly exposed gypsum or to oxidation of freshly exposed pyrite, or both, in spoil. The exposure of the minerals probably results from disturbance of the drift and bedrock overburden during mining.

The general chemical processes that occur as water moves into spoil are dissolution and precipitation of calcite, dissolution of dolomite, consumption of oxygen gas, consumption and release of carbon dioxide gas, dissolution of pyrite and gypsum, precipitation of goethite (or iron hydroxide), and release of sodium ions by ion exchange. When all the pyrite has been consumed through oxidation, the quality of water in the spoil probably will begin to improve. How long this might take is not known.

\section{INTRODUCTION}

Strip mining of coal has a significant effect on the near-surface environment because overburden, the material above the coal, is removed successively in furrows or strips. After the first strip cut, the broken and mixed overburden from successive cuts is placed into the previous cut forming spoil. The last cut is left open and eventually may fill with water, forming a high-wall lake. Strip mining can alter both the hydraulic and geochemical characteristics of hydrologic systems in the mined area.

To administer coal-mining regulations, State and Federal agencies need to assess the probable effects of strip mining on the movement and quality of ground water. However, to date (1984), information about the effects has been insufficient to make these assessments.

\section{Purpose and Scope}

The purpose of this study was to describe the ground-water hydrology and general geochemical processes affecting ground-water quality in the Macon-Huntsville area of north-central Missouri (fig. 1). Specifically, the objectives were to determine the ground-water conditions in the area and the effects of strip mining of coal with a substantial sulfur content in a humid climate on water quality of high-wall lakes and aquifers.

An extensive data-collection program was begun during 1980 to provide hydrologic and geochemical information for the study. Existing wells in the study area were inventoried. In addition, 15 observation wells were installed in or near mine spoil emplaced during 1940 (fig. 2), 1952 (fig. 3), and 1968 (fig. 4) in southern Macon County. Cuttings were collected during drilling and were analyzed for physical properties and mineralogy. Water levels in the observation wells were measured monthly, and several sets of water samples were collected from the wells for on-site and laboratory chemical analysis. Staff gages were installed in nine lakes in spoil to determine the relationship between the lakes and ground water in the spoil. Samples of water from the lakes were collected and analyzed for specific conductance, $\mathrm{pH}$, temperature, and carbonate and bicarbonate concentrations (see "Supplemental Data" section at the back of the report for data collected during the study). 


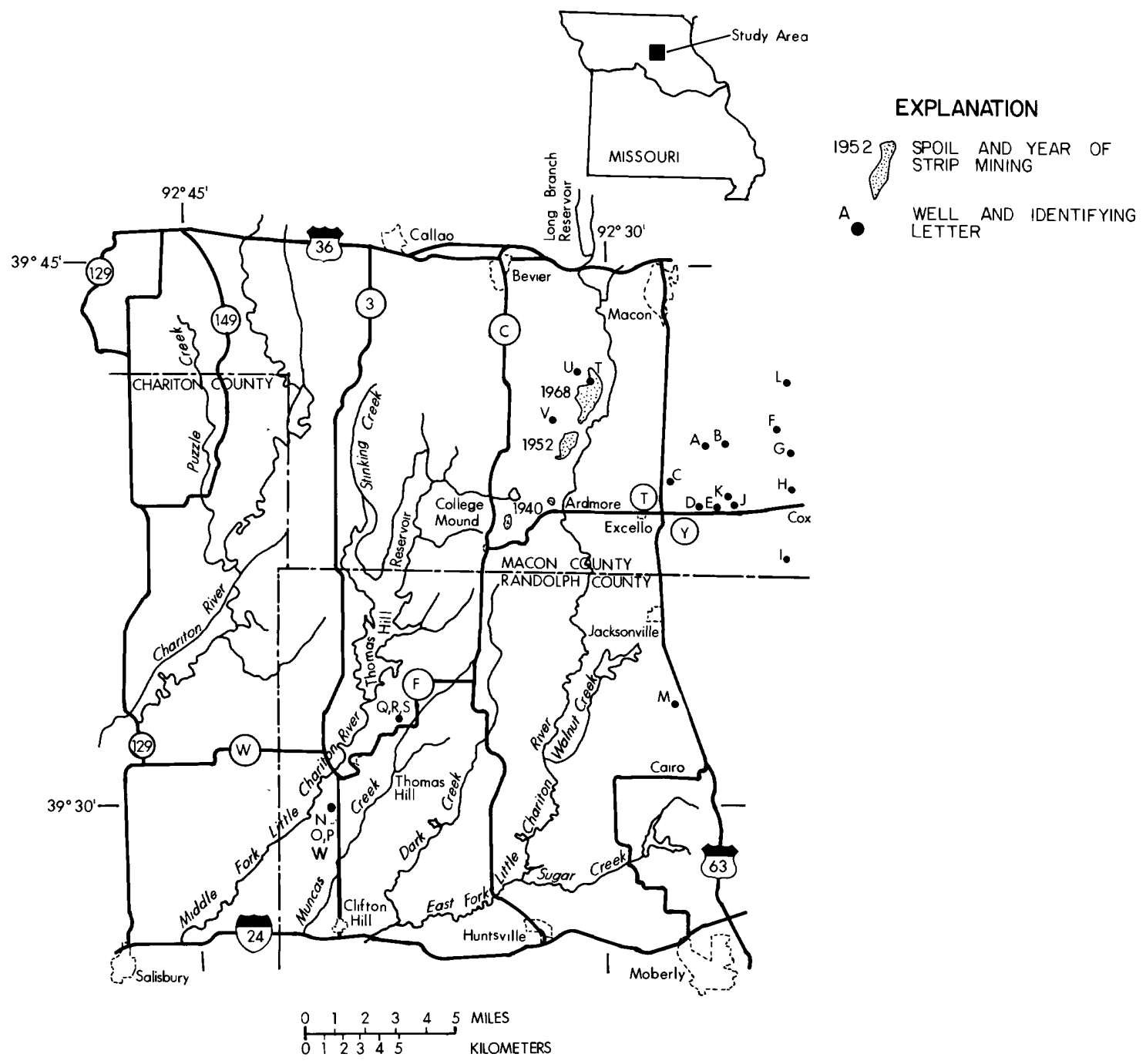

Figure 1.--Location of study area, spoil areas, and wells outside of spoil areas. 


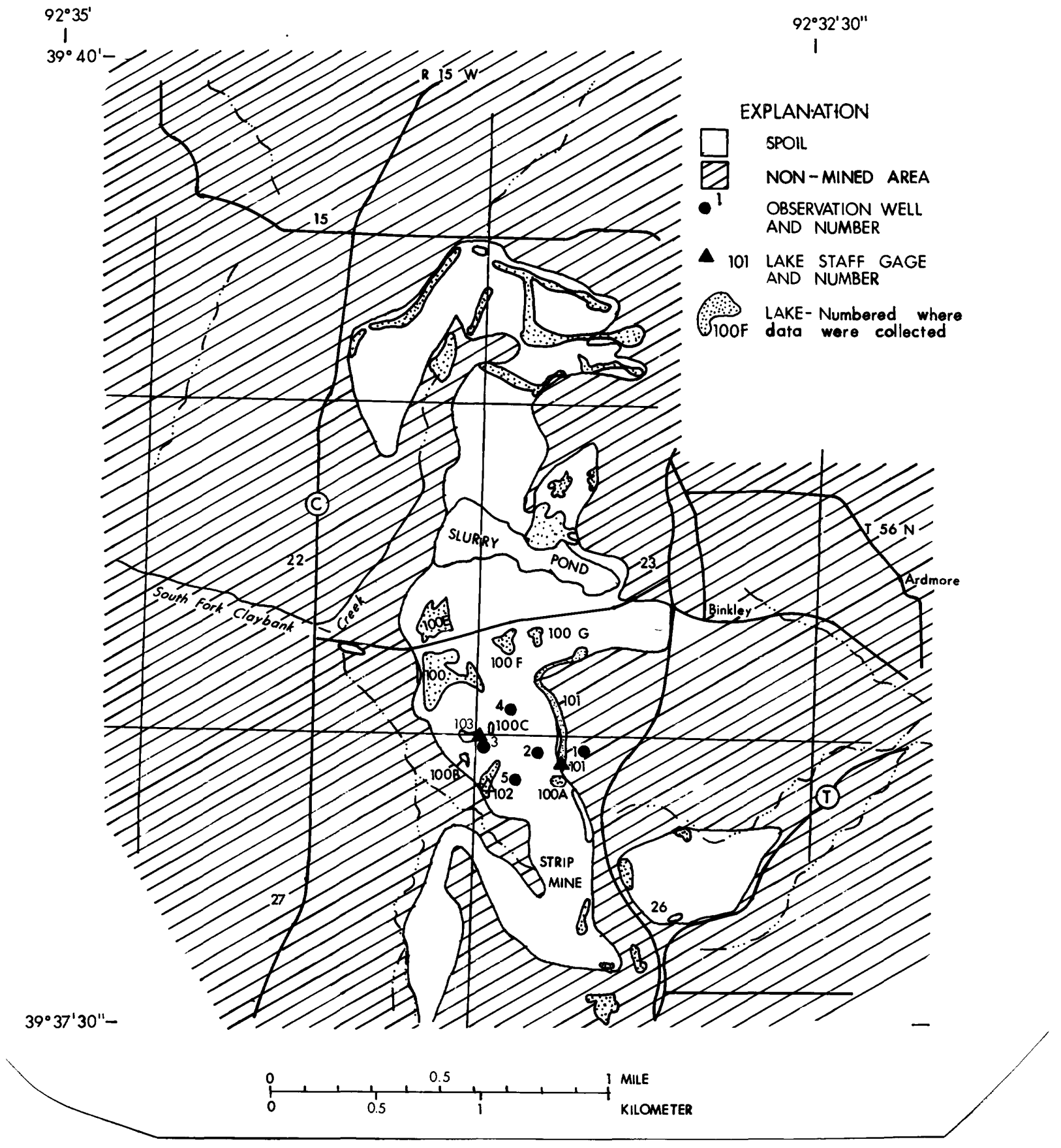

Figure 2.--Location of observation wells, lake staff gages, and miscellaneous lakes in 1940 spoil. 


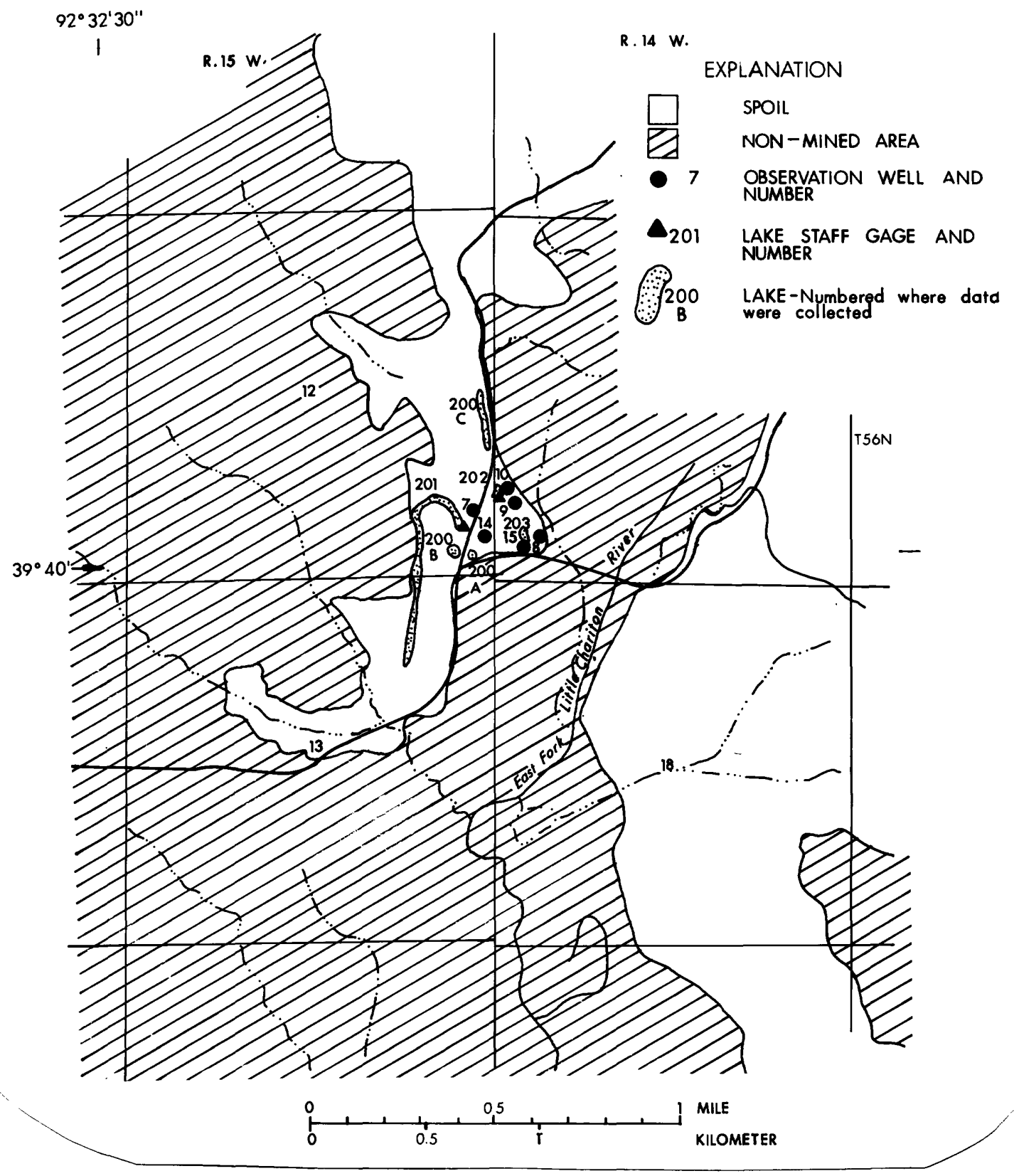

Figure 3.--Location of observation wells, lake staff gages, and miscellaneous lakes in 1952 spoil. 


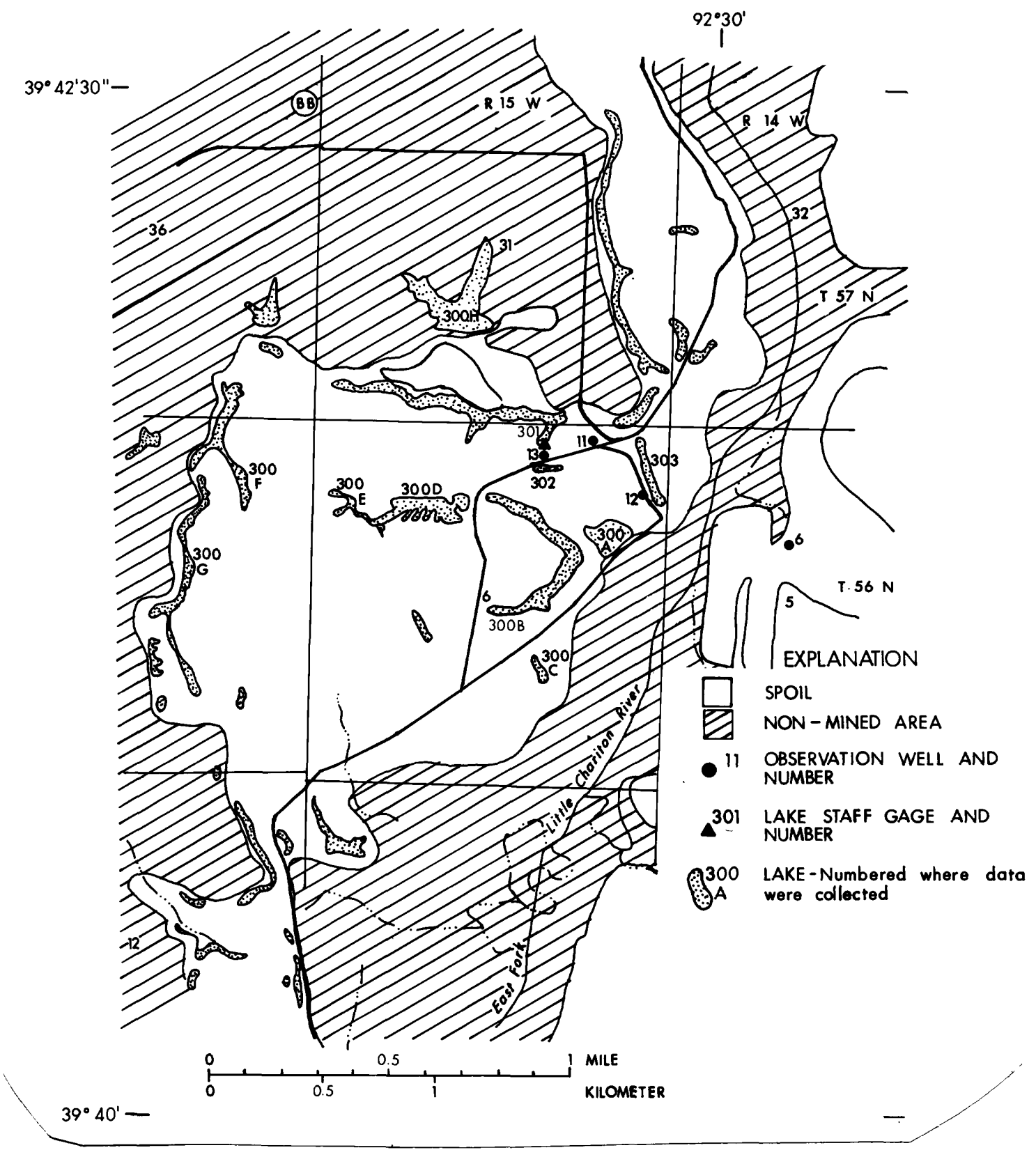

Figure 4.--Location of observation wells, lake staff gages, and miscellaneous lakes in 1968 spoil. 


\section{Previous Investigations}

Studies of the coal resources of Missouri have been made by Gentile (1967), Robertson (1971 and 1973), Robertson and Smith (1981), and Searight (1967). Studies of ground-water resources in and near the study area have been made by Haliburton Associates (1981), Horner and Shifrin, Inc. (1981), and Vaill and Barks (1980). Studies made by Draney (1982); Lewis (1982); Older (1982); and Seifert (1982) relate directly to certain geologic and hydrologic aspects of the study area.

Physiography and Drainage

North-central Missouri has been glaciated and is in the Dissected Till Plains physiographic area (Fenneman, 1938). The topography consists of rolling hills with about 100 feet of relief. The major streams, East and Middle Forks Little Chariton River, drain southward to the Missouri River. Two major reservoirs, Thomas Hill and Long Branch, are located in the study area (see fig. 1).

\section{Climate}

North-central Missouri has a humid climate. Mean annual precipitation for 1941-70 at Macon (fig. 1) was 38.7 inches (National Weather Service, 1981-83). The mean annual temperature was $52.1{ }^{\circ} \mathrm{F}$ (National Weather Service, 1981-83). Mean annual potential evapotranspiration is 28 inches (Lewis, 1982, p. 23) and mean annual runoff is 8 to 9 inches (Skelton, 1971, plate 1).

Precipitation at Macon (fig. 5) was 52.4 inches during 1981; 47.4 inches during 1982; and 41.7 inches during 1983 (National Weather Service, 1981-83; and U.S. Army, Corps of Engineers, Long Branch Reservoir, oral commun., 1983). The 1981 and 1982 values were considerably greater than the mean annual precipitation.

\section{Coal Mining in Missouri}

Missouri has an estimated 47 billion tons of coal reserves, of which 18 billion tons are identified, 12 billion tons are hypothetical, and 17 billion tons are speculative (Robertson and Smith, 1981, p. 12-13). Of the 18 billion tons of identified reserves, 5 billion tons are considered recoverable. Of these recoverable reserves, 2 billion tons are considered recoverable by strip mining. The coal in Missouri is bituminous and has a relatively large sulfur content. In a study by Wedge and others (1976), the sulfur content of Missouri coal ranged from 2.7 to 6.9 percent, averaging 4.3 percent.

Macon County produced 43 million tons of coal from 1889 to 1964 (Gentile, 1967), which was more than any other county in Missouri. During the same period, Randolph County produced 24 million tons of coal. Both underground and strip mines have been significant in the production of coal. About 37 percent of the total coal produced has been strip mined and almost all coal produced since the mid-1960's has been strip mined. In the 108 square-mile drainage of East Fork Little Chariton River between Macon and Huntsville (see fig. 1), 14 percent of the area has been discupted by strip mining. 


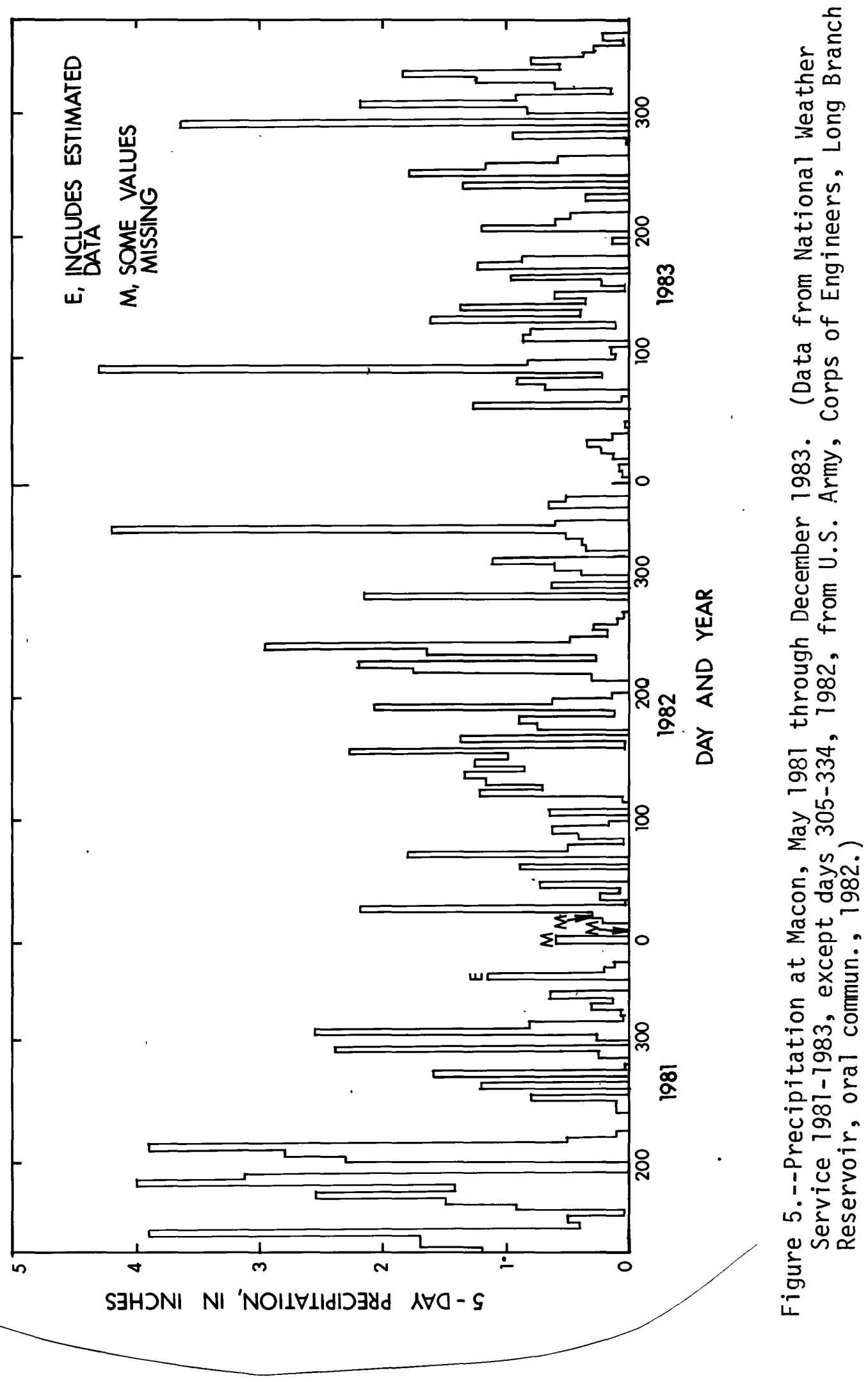


The hilly topography has made contour strip mining the method of choice in Macon and Randolph Counties (Vaill and Barks, 1980). By this method, the overburden is removed successively in strips following the contour of the land (fig. 6). Mining generally continues until the thickness of the overburden makes mining uneconomical or until the thickness of the overburden exceeds the removal capacity of the equipment. The maximum thickness of overburden removed in Missouri generally is not more than 150 feet.

Before 1972, reclamation was not required and ordinarily was not practiced in Missouri mining operations. After the coal was removed, strip mines were abandoned and left to natural processes. The mine areas were not recontoured, topsoil was not replaced, and the fertility of the surface material varied widely. As a result, vegetation varies from sparse to dense in unreclaimed areas.

Public Law 95-87 (U.S. Department of the Interior, Office of Surface Mining Reclamation and Enforcement, 1979) requires that land stripped for mining be reclaimed. With reclamation the spoil is recontoured, the topsoil is replaced, and the area is reseeded and revegetated. However, high-wall lakes are still a characteristic feature.

\section{Acknow ledgments}

We are grateful for the cooperation of the Associated Electric Cooperative, Inc., which owns much of the property where this study was made; and to the many employees who offered assistance, particularly Kimery C. Vories and Daniel L. Henry. Also, many thanks to Scott and Carol Phillips, owners of Phillips Farms, who permitted the installation of wells and staff gages on their property.

\section{GEOLOGY}

\section{Stratigraphy}

The near-surface geology of northern Missouri consists of Quaternary alluvium, loess, and glacial drift overlying Pennsylvanian bedrock (fig. 7). Alluvium primarily is present in the larger stream valleys and consists of sand, silt, and clay. Maximum thickness of the alluvium is about 50 feet. The loess is a post-glacial deposit composed of fine-grained, wind-blown material and primarily occurs on the higher ridges. The loess generally is 5 to 10 feet thick (Gentile, 1967). The glacial drift, consisting of till and outwash deposits, is composed of poorly sorted sand, silt, and clay with some well-sorted sand lenses. Glacial drift is present throughout most of the study area, except where locally eroded, and is as much as 150 feet thick, generally thinning to the south. In some areas, fractures occur in the glacial drift (Horner and Shifrin, Inc., 1981).

Pennsylvanian bedrock underlies the entire area (fig. 8) and consists of shale, limestone, sandstone, and coal with shale predominating (Gentile, 1967). Total thickness of Pennsylvanian bedrock in southwest Macon County is about 280 feet. Coal seams of interest are the Mulky and Bevier-Wheeler seams that generally are within 100 feet of the land surface. 


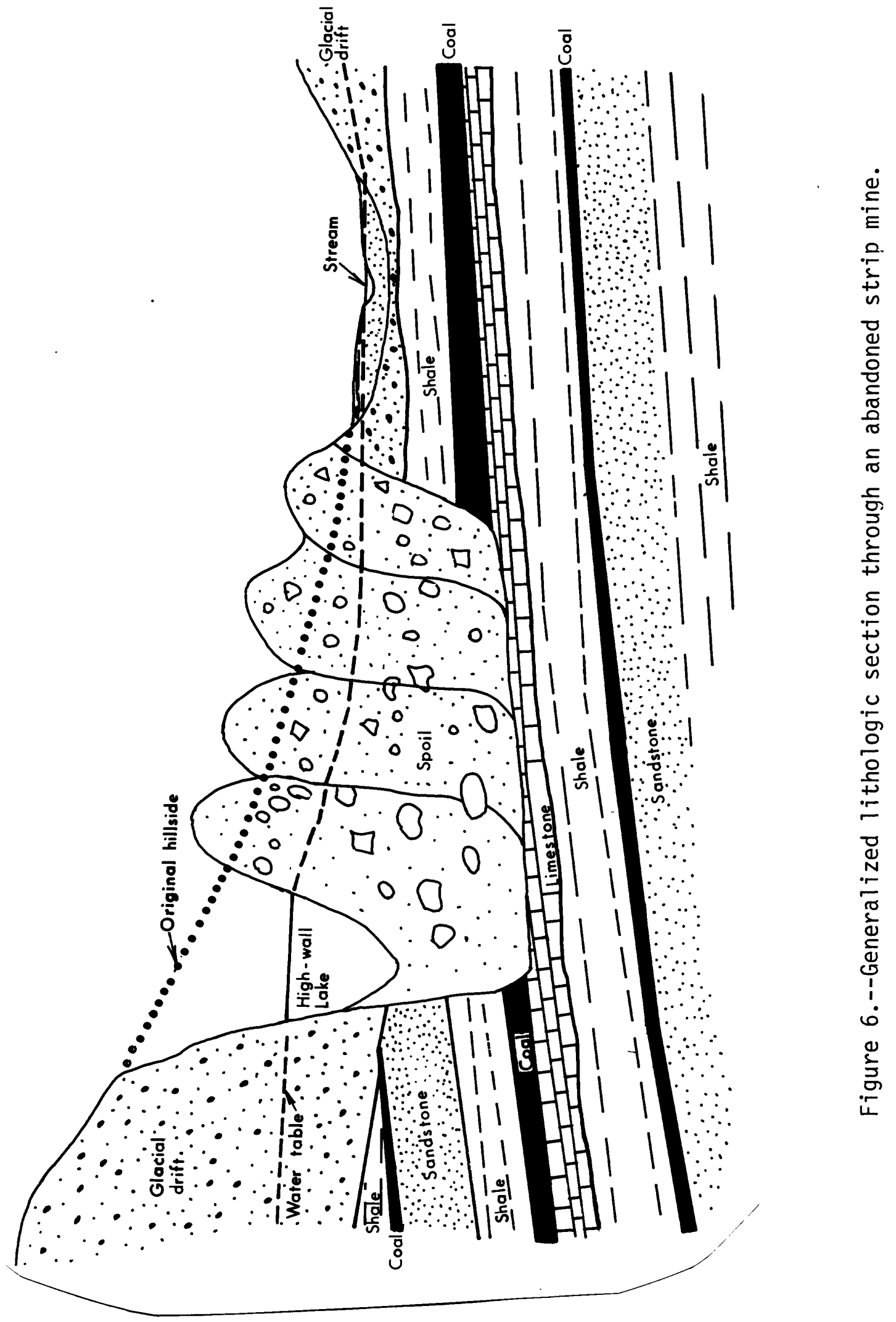




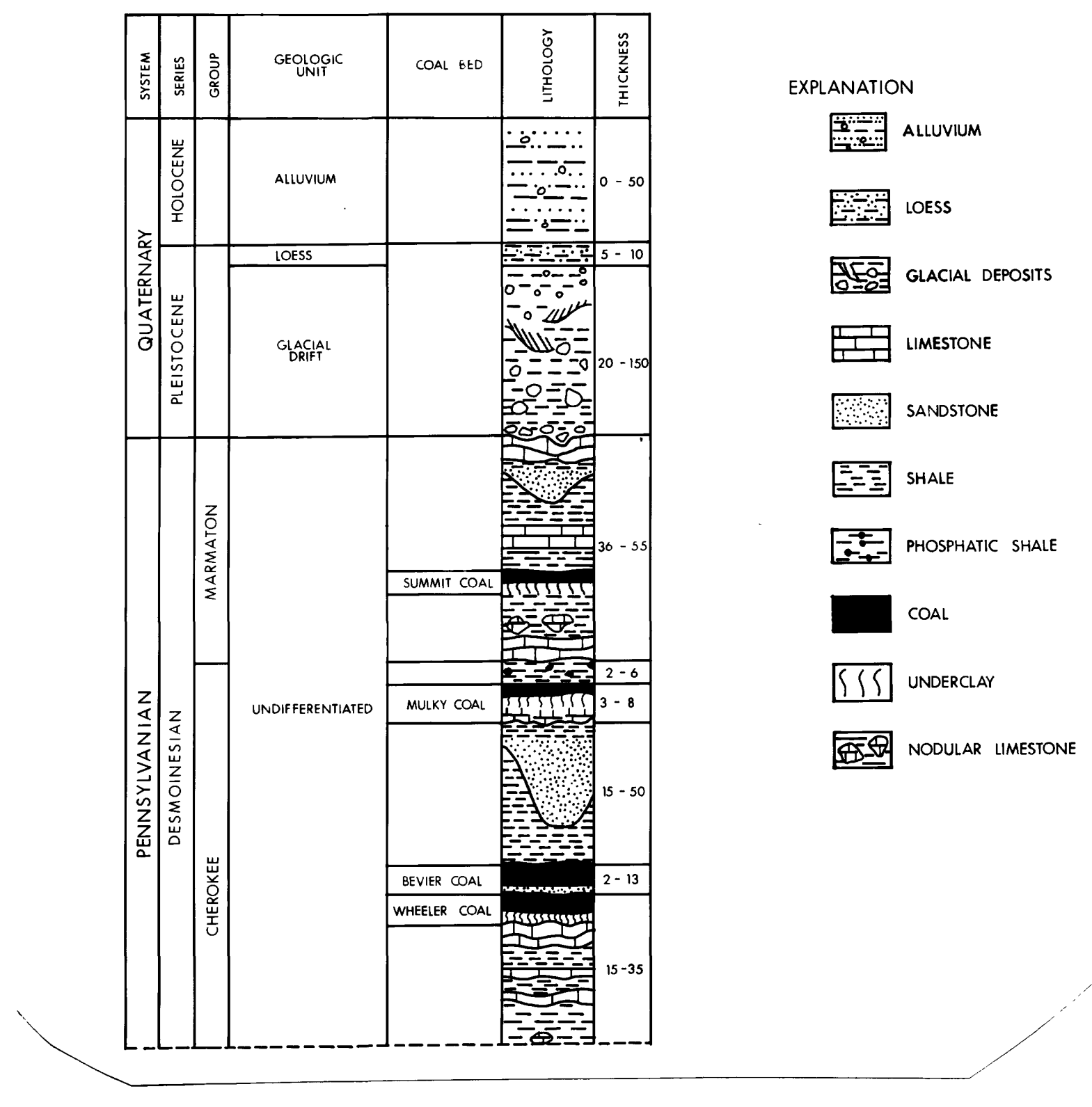

Figure 7.--Generalized stratigraphy of study area. (Modified from 01der, 1982; and Gentile, 1967.) 


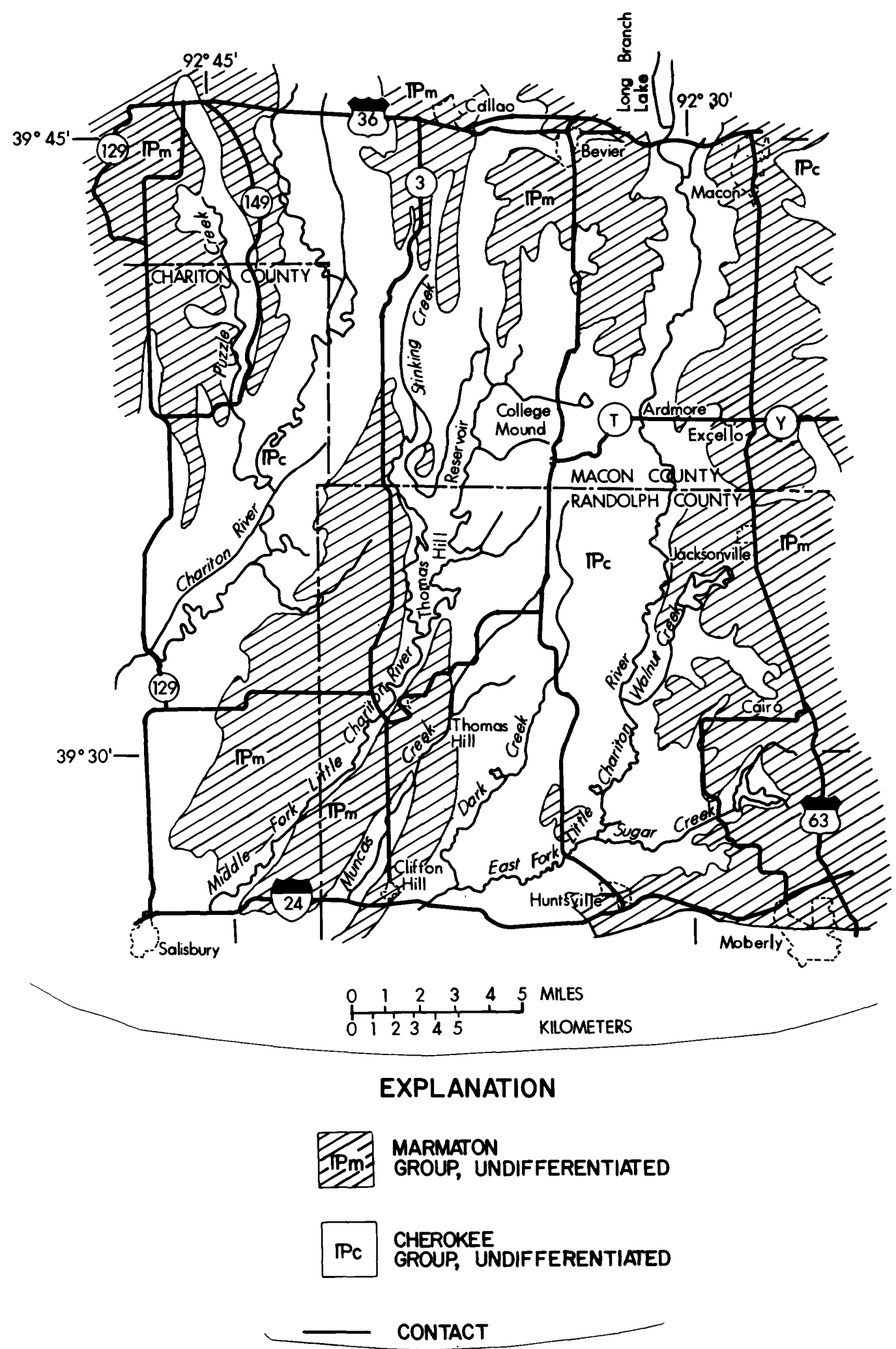

Figure 8.--Pennsylvanian bedrock in the study area. (Geology by Anderson, 1979.) 
Soils in the study area vary depending on the parent material (Vaill and Barks, 1980). Soils formed from alluvium or loess are rich and fertile, and soils formed from glacial drift are less fertile.

Spoil is present where surface mining has occurred. The spoil consists of a heterogeneous mixture of glacial drift and broken bedrock. The composition of spoil varies from place to place depending on the relative quantities of disturbed glacial drift and bedrock. Thicknesses are about 30 to 55 feet in the 1940 spoil, 30 to 40 feet in the 1952 spoil, and 25 to 110 feet in the 1968 spoil.

\section{Mineralogy}

The major minerals present in the spoil are quartz, calcite, dolomite, and various clays. Pyrite, gypsum, goethite, amorphous iron hydroxide, and jarosite also are present (older, 1982). Quartz, is the dominant mineral in the sand-silt fraction of glacial drift and spoil (table 1).

Calcite and dolomite are present in approximately equal quantities ranging from about 2 to 10 percent and averaging about 4 to 5 percent (table 2 ). Calcite generally was observed in the clay fraction (grains less than 2 micrometers in diameter).

The clay-mineral groups are calcium montmorillonite, vermiculite, kaolin, illite, mixed-layer illite-vermiculite, and degraded chlorite (Older, 1982). Calcium montmorillonite, vermiculite, kaolin, and illite probably are derived from the glacial drift; kaolin, illite, and also small quantities of vermiculite probably are derived from the bedrock. The average quantity of clay in the spoil was 39 percent. Calcium montmorillonite has the largest cation-exchange capacity of the clay present, although iron-hydroxide coatings on the clay probably inhibit exchange. The major minerals or mineral groups observed or expected to be in the spoil and selected for geochemical modeling are listed in table 3 (Seifert, 1982).

\section{GROUND-WATER MOVEMENT}

Alluvium, glacial drift, bedrock, and spoil are aquifers in the study area. The alluvial aquifer generally is confined, although unconfined conditions may exist locally. The glacial drift and bedrock aquifers generally are confined. The spoil aquifer is unconfined.

\section{Transmissivity}

Data on hydraulic properties of the aquifers are few. A summary of available data is given in table 4. Although the ranges of known values vary considerably, transmissivities generally are greatest for the spoil and decrease in the following order: alluvium, glacial drift, bedrock above the coal, and bedrock below the coal. Transmissivities determined for the spoil with permeameters in the laboratory were considerably less than those determined in wells. However, the investigators (Shell Engineering Associates, 1981) stated that the samples in the permeameters were packed too tightly. 
Table 1.--Sand-silt-clay grain-size distribution in glacial drift [Data from Draney, 1982]

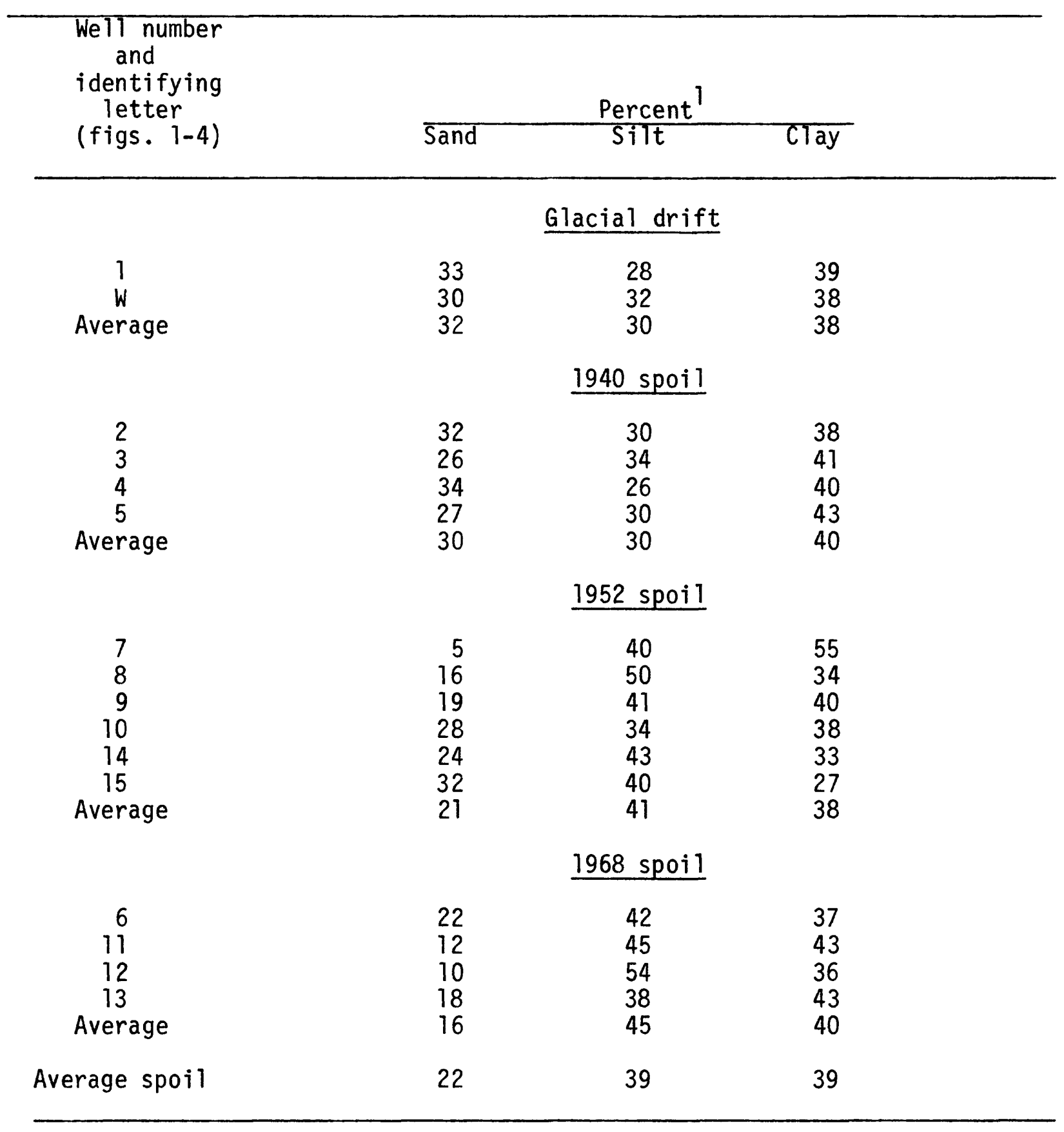

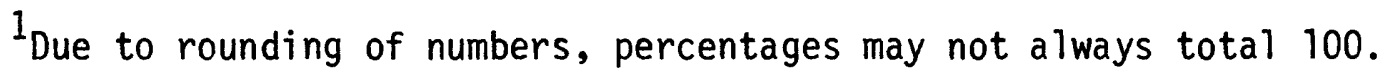


Table 2.--Percentage of calcite and dolomite by weight in glacial drift and spoil

[Data from Draney, 1982]

\begin{tabular}{|c|c|c|}
\hline $\begin{array}{c}\text { Well number } \\
\text { and } \\
\text { identifying } \\
\text { letter } \\
\text { (figs. } 1-4 \text { ) }\end{array}$ & \multicolumn{2}{|c|}{ Percentage, by weight } \\
\hline & \multicolumn{2}{|c|}{ Glacial drift } \\
\hline \multirow[t]{2}{*}{$\begin{array}{c}1 \\
\text { W } \\
\text { Average }\end{array}$} & $\begin{array}{l}5.8 \\
5.9 \\
5.8\end{array}$ & $\begin{array}{l}4.7 \\
5.5 \\
5.1\end{array}$ \\
\hline & \multicolumn{2}{|c|}{1940 spoil } \\
\hline $\begin{array}{c}2 \\
3 \\
4 \\
5 \\
\text { Average }\end{array}$ & $\begin{array}{l}6.4 \\
4.0 \\
7.1 \\
3.4 \\
5.2\end{array}$ & $\begin{array}{l}5.4 \\
3.4 \\
5.4 \\
3.6 \\
4.4\end{array}$ \\
\hline $\begin{array}{c}5 \\
\text { Average }\end{array}$ & \multicolumn{2}{|c|}{1952 spoil } \\
\hline \multirow[t]{2}{*}{$\begin{array}{c}7 \\
8 \\
9 \\
10 \\
14 \\
15 \\
\text { Average }\end{array}$} & $\begin{array}{l}1.9 \\
2.5 \\
3.9 \\
9.9 \\
3.1 \\
4.6 \\
4.3\end{array}$ & $\begin{array}{l}4.8 \\
2.4 \\
3.2 \\
8.2 \\
2.8 \\
2.8 \\
4.0\end{array}$ \\
\hline & \multicolumn{2}{|c|}{1968 spoil } \\
\hline $\begin{array}{c}6 \\
11 \\
12 \\
13 \\
\text { Average }\end{array}$ & $\begin{array}{l}6.0 \\
7.3 \\
6.4 \\
4.7 \\
6.1\end{array}$ & $\begin{array}{l}4.7 \\
4.9 \\
5.5 \\
4.7 \\
5.0\end{array}$ \\
\hline Average spoil & 5.1 & 4.4 \\
\hline
\end{tabular}




\section{Table 3.--Minerals selected for geochemical modeling}

[Modified from Seifert, 1982]

Adularia $\left(\mathrm{KATSi}_{3} \mathrm{O}_{8}\right)$

Albite $\left(\mathrm{NaAlSi}_{3} \mathrm{O}_{8}\right)$

Alunite $\left[\mathrm{KAl}_{3}\left(\mathrm{SO}_{4}\right)_{2}(\mathrm{OH})_{8}\right]$

Amorphous aluminum hydroxide $\left[\mathrm{Al}(\mathrm{OH})_{3} \mathrm{~A}\right]$

Amorphous iron hydroxide $\left[\mathrm{Fe}(\mathrm{OH})_{3} \mathrm{~A}\right]$

Calcite $\left(\mathrm{CaCO}_{3}\right)$

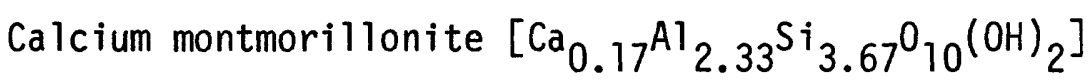

Dolomite $\left[\mathrm{CaMg}\left(\mathrm{CO}_{3}\right)_{2}\right]$

Goethite $[\mathrm{FeO}(\mathrm{OH})]$

Gypsum $\left(\mathrm{CaSO}_{4} \cdot 2 \mathrm{H}_{2} \mathrm{O}\right)$

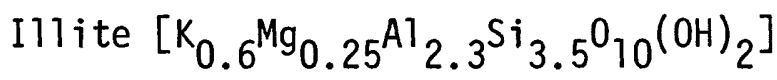

Jarosite $\left[\mathrm{KFe}\left(\mathrm{SO}_{4}\right)_{2}(\mathrm{OH})_{6}\right]$

Kaolinite $\left[\mathrm{Al}_{2} \mathrm{Si}_{2} \mathrm{O}_{5}(\mathrm{OH})_{4}\right]$

Pyrite $\left(\mathrm{FeS}_{2}\right)$

Quartz $\left(\mathrm{SiO}_{2}\right)$

Siderite $\left(\mathrm{FeCO}_{3}\right)$ 


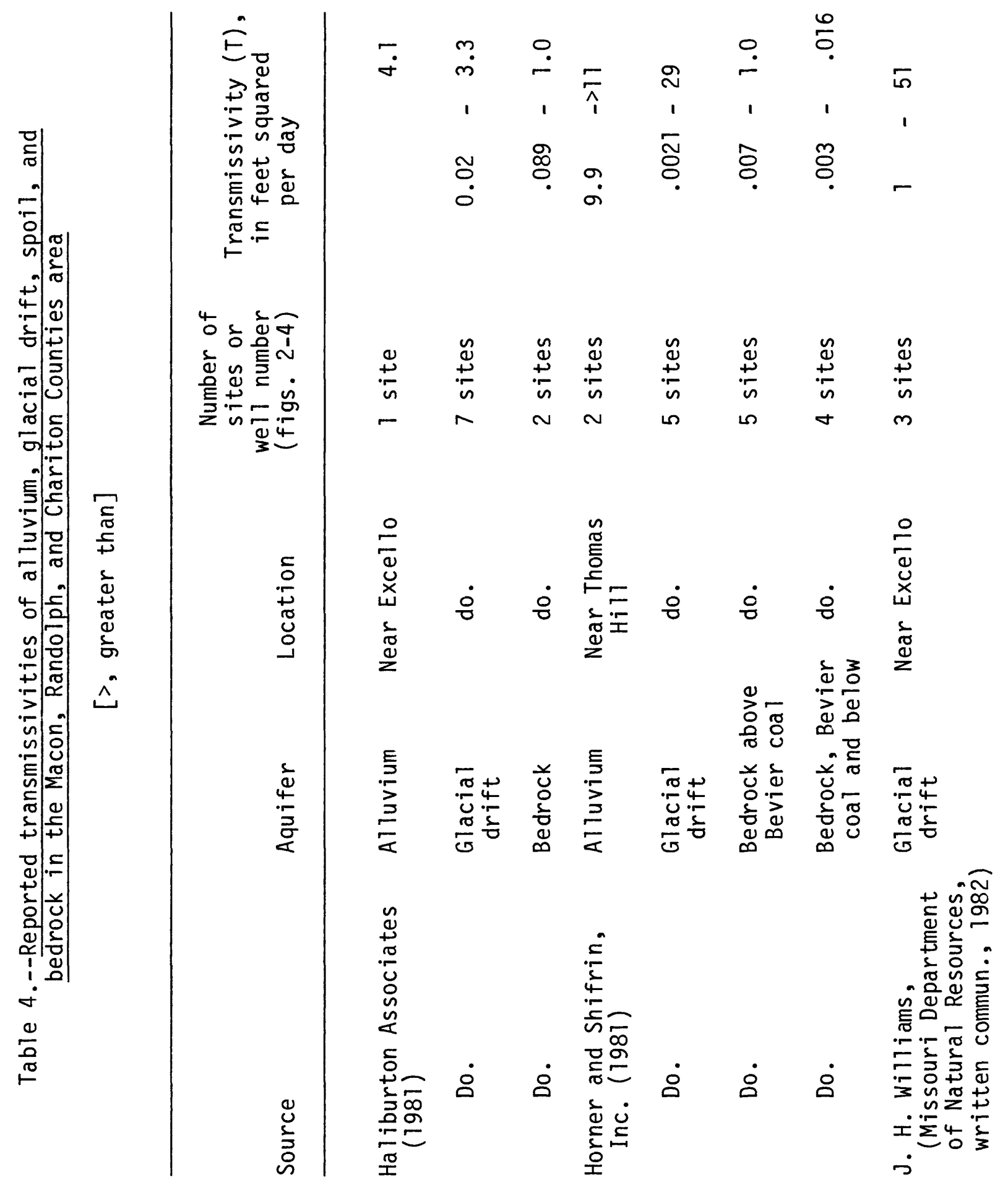




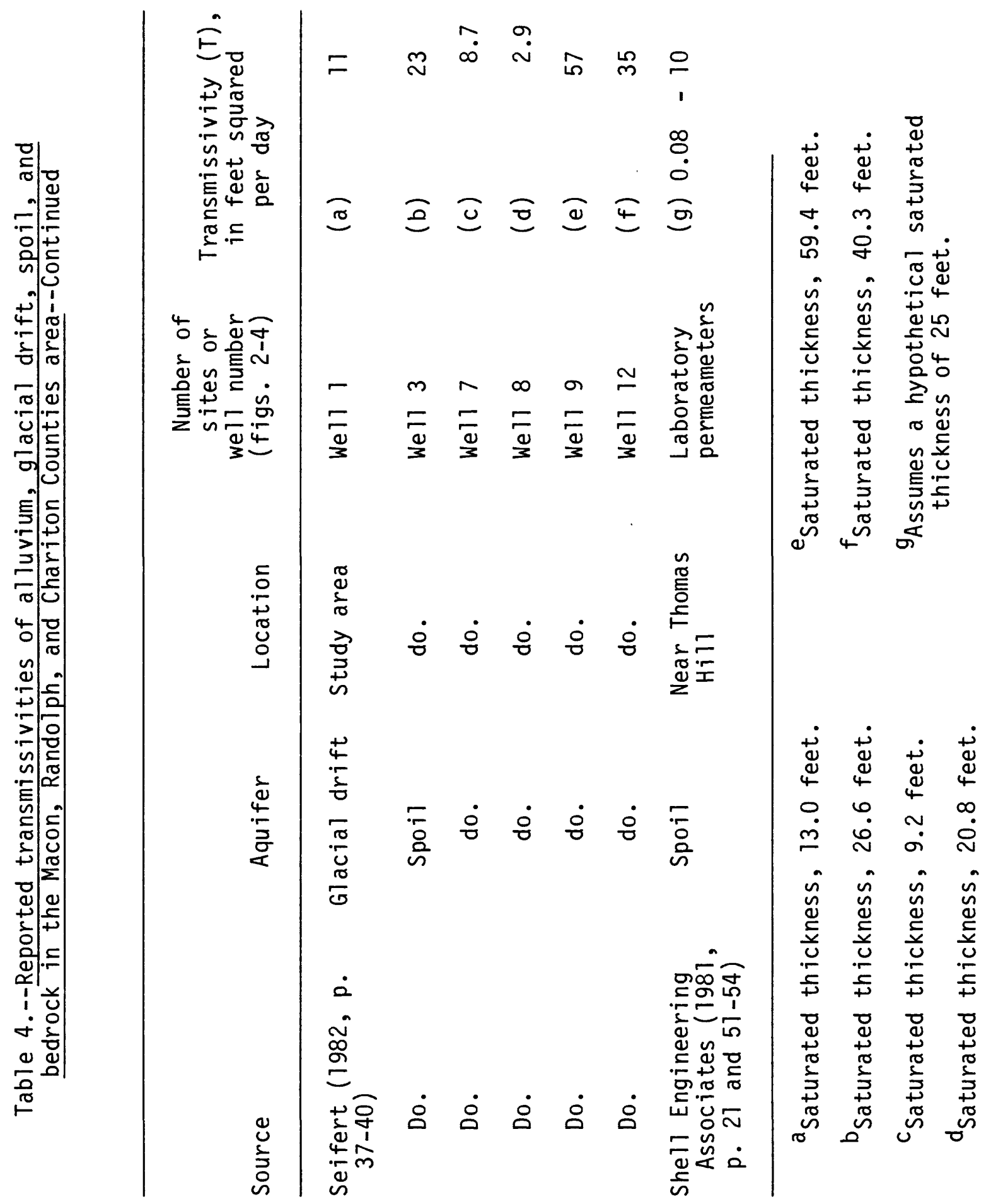


During well drilling in spoil and in glacial drift close to the spoil, layers were encountered in which penetration was rapid and large quantities of drilling fluid containing Revert ${ }^{l}$ were lost. This was true for wells 1, 6, 7, 11 and 12 (figs. 2, 3, and 4). These wells all had yields of more than 5 gallons per minute. Attempted slug tests failed in wells 1, 7, 11, and 12 because recovery was too rapid to measure manually.

\section{Recharge and Discharge}

Recharge to the alluvium occurs by infiltration of precipitation and by lateral and probably vertical flow from adjacent aquifers. Recharge probably occurs during periods of high stream stage. The rate of recharge by infiltration of precipitation is unknown, but probably is small.

Recharge to glacial drift occurs by infiltration of precipitation and lateral flow from adjacent aquifers. The potential rate of infiltration in glacial drift is about 0.06 inch per hour (Dennis K. Potter, U.S. Soil Conservation Service, oral commun., April 1984). Due to extensive layers of clay in the glacial drift, infiltration of precipitation probably occurs mainly in localized areas where sand lenses or fractures are present. The actual rate of recharge to the glacial drift probably is small. Based on tritium dating, Haliburton Associates (1981, p. 173-174) report that no significant vertical recharge to the deeper parts of glacial drift has occurred since 1952 in an area east of Excello. By means of a ground-water flow model, Horner and Shifrin, Inc. (1981, p. 32) estimate an annual recharge rate of $4 \times 10^{-5}$ inch to the glacial drift throughout a 100 -square-mile area in Randolph and Chariton Counties near Thomas Hill. However, Lewis (1982, p. 38-40), also using a ground-water flow model for part of the Excello basin east of the study area, determined a possible range of annual recharge to the glacial drift of 0.2 to 5.2 inches.

Recharge to bedrock probably occurs by infiltration of precipitation and vertical flow from overlying alluvium and glacial drift. The rate of recharge is unknown, but probably is small.

Recharge to spoil is from precipitation, lateral flow from glacial drift, and lateral and vertical flow from bedrock. Precipitation probably is the major source of recharge, both directly by infiltration and indirectly as leakage from lakes. The potential rate of infiltration into spoil ranges from 0.2 to 0.6 inch per hour (Dennis K. Potter, U.S. Soil Conservation Service, oral commun., April 1984). The annual recharge to the spoil is unknown.

Reclamation of spoil areas, as is currently (1984) practiced in newer surface mines, may have a significant effect on recharge. Smoothing of the reclaimed surface eliminates many small ponds and puddles conducive to infiltration, although high-wall lakes and sediment ponds are retained. In

luse of trade names in this report is for identification purposes only and does not constitute endorsement by the U.S. Geological Survey. 
addition, topsoil is replaced and planted with grasses and legumes. Topsoil would most likely be less permeable than the unreclaimed spoil surface, and thick vegetative cover would result in an increased evapotranspiration loss. Recharge in reclaimed spoil, although less than in unreclaimed spoil, would still be greater than in nonmined parts of the study area.

Ground-water discharge from glacial drift, bedrock, and spoil is to the alluvium. The alluvium generally discharges to streams.

\section{Potentiometric Surface}

The potentiometric surface in the shallow aquifers (alluvium, glacial drift, and spoil) in parts of Macon, Randolph, and Chariton Counties generally conformed to the topography (fig. 9). The larger streams and some of the smaller streams gain from ground-water inflow during wet weather. However, during extended periods of dry weather, ground-water contribution decreases and may be entirely consumed by evapotranspiration.

In and near the 1940 spoil, the potentiometric surface sloped away from high-wall lake 101 on the east, west, and south sides (fig. 10). Ground-water flow on the east side was to tributaries of the East Fork Little Chariton River; ground-water flow on the west side was toward the South Fork Claybank Creek; and ground-water flow to the south probably contributes to both surface-water systems. Ground-water flow immediately north of lake 101 was toward the lake. The hydraulic gradient in the spoil area ranged from about 110 to 210 feet per mile outside the spoil and from 40 to 120 feet per mile inside the spoil.

In and near 1952 spoil, the potentiometric surface generally sloped from west to east toward the East Fork Little Chariton River (fig. 11). The hydraulic gradient outside the spoil was not determined, but inside the spoil the hydraulic gradient ranged from 120 to 400 feet per mile.

In and near 1968 spoil, the potentiometric surface sloped from north and west to the east toward the East Fork Little Chariton River (see fig. 11). The hydraulic gradient was about 240 feet per mile outside the spoil on the north and west and ranged from 20 to 80 feet per mile inside the spoil.

Because precipitation in the study areas was considerably greater than normal during 1981-82, the altitudes of the potentiometric surfaces during 1981-83 also may have been greater than normal. The response time between precipitation and changes in the potentiometric surfaces is not known, although it probably is days or months because altitudes of water in observation wells in or near spoil have considerable seasonal variability. Changes of as much as 13.5 feet were measured during 1981-83 (figs. 12-14). 


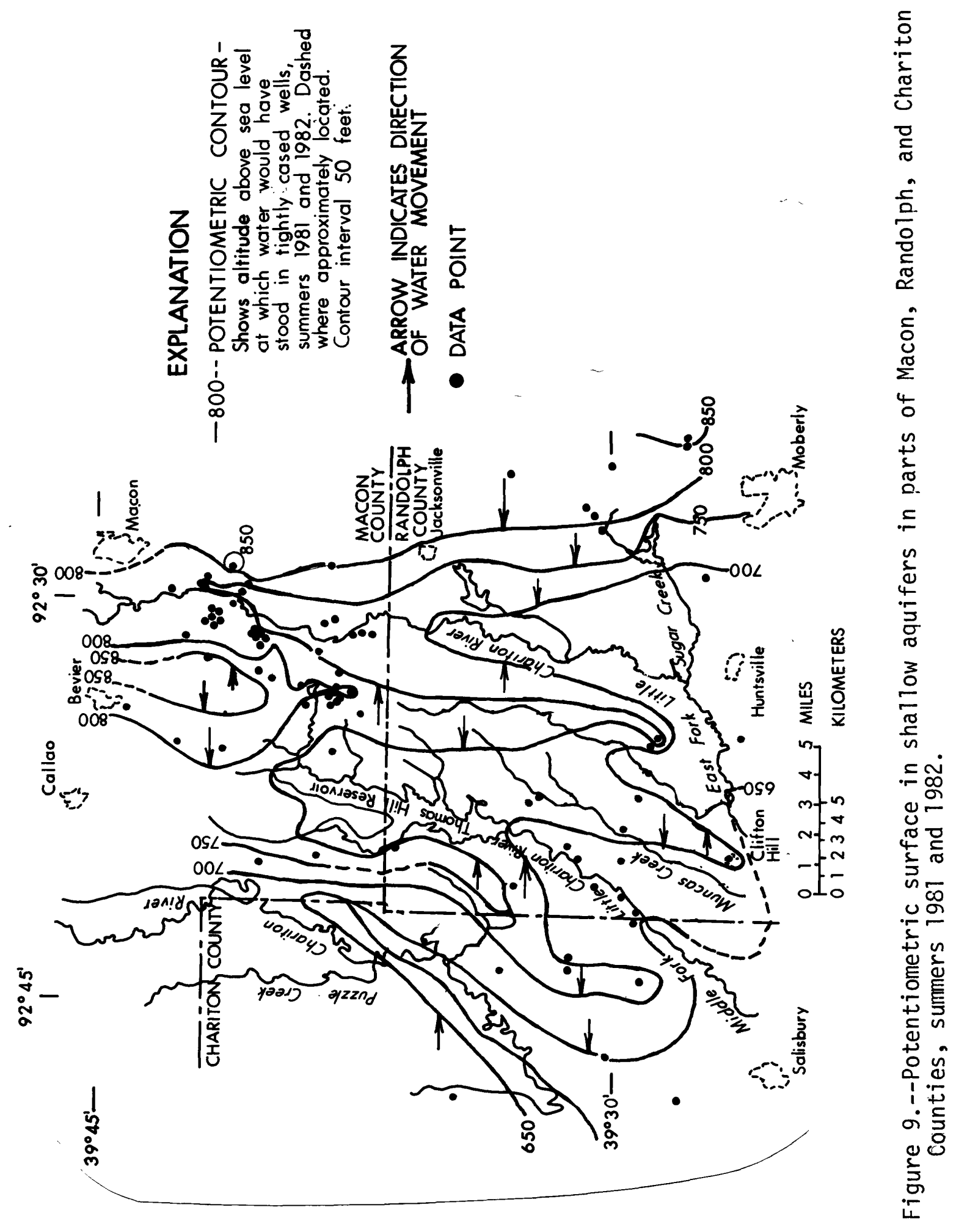




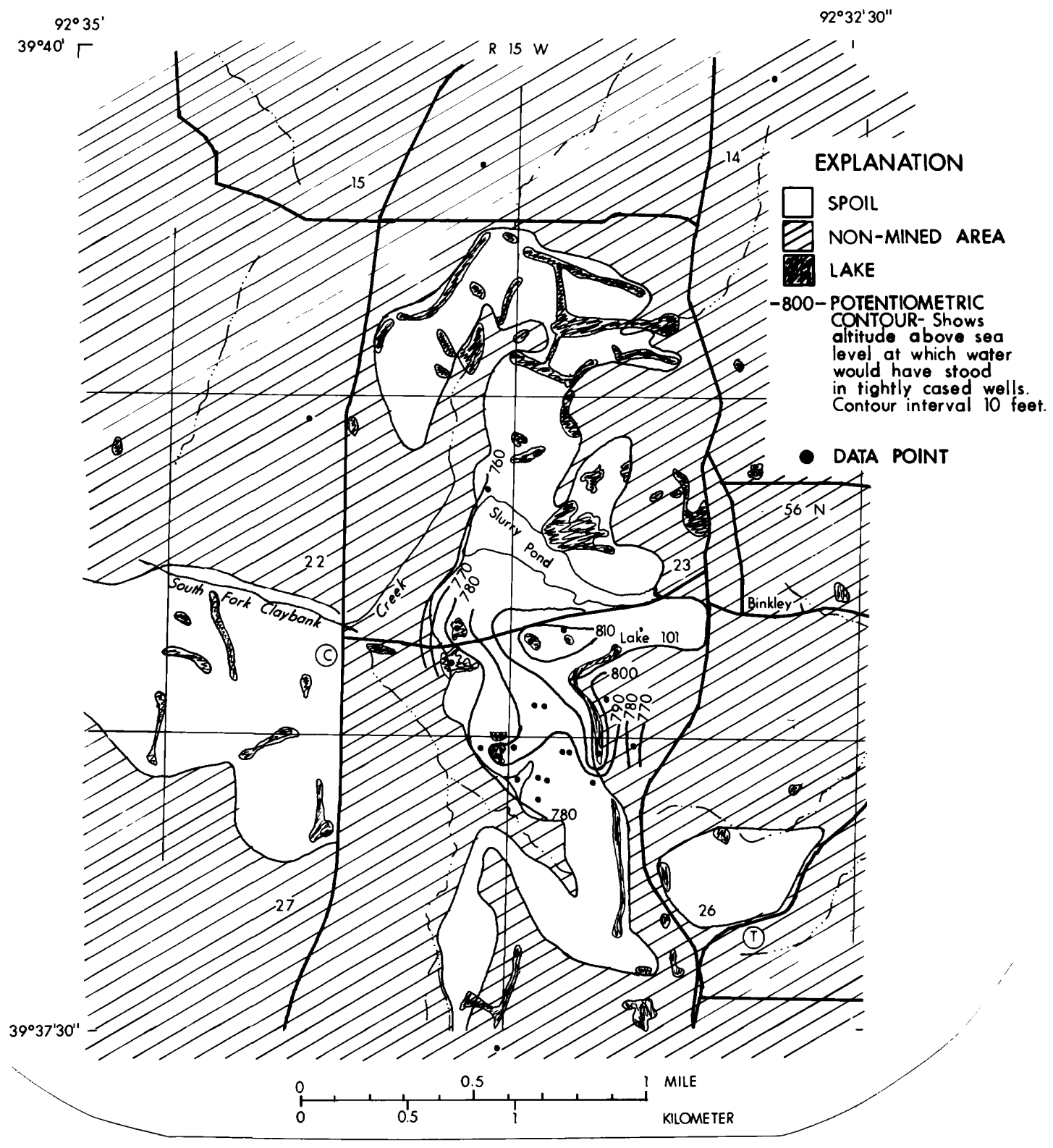

Figure 10.--Potentiometric surface of shallow aquifers in 1940 spoil, summer 1983. 


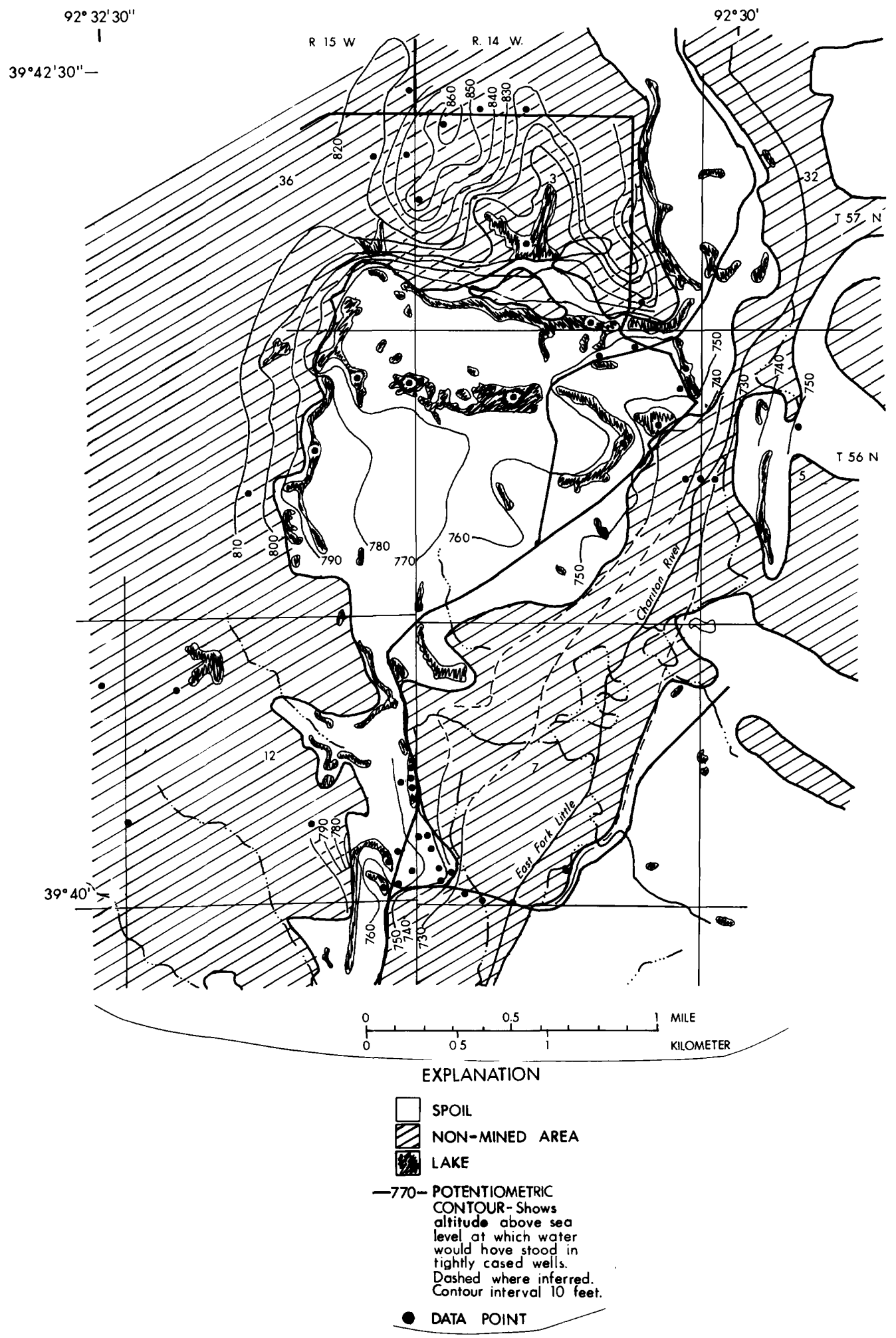

Figure 11.--Potentiometric surface of shallow aquifers in 1952 and 1968 spoil, summer 1983. 


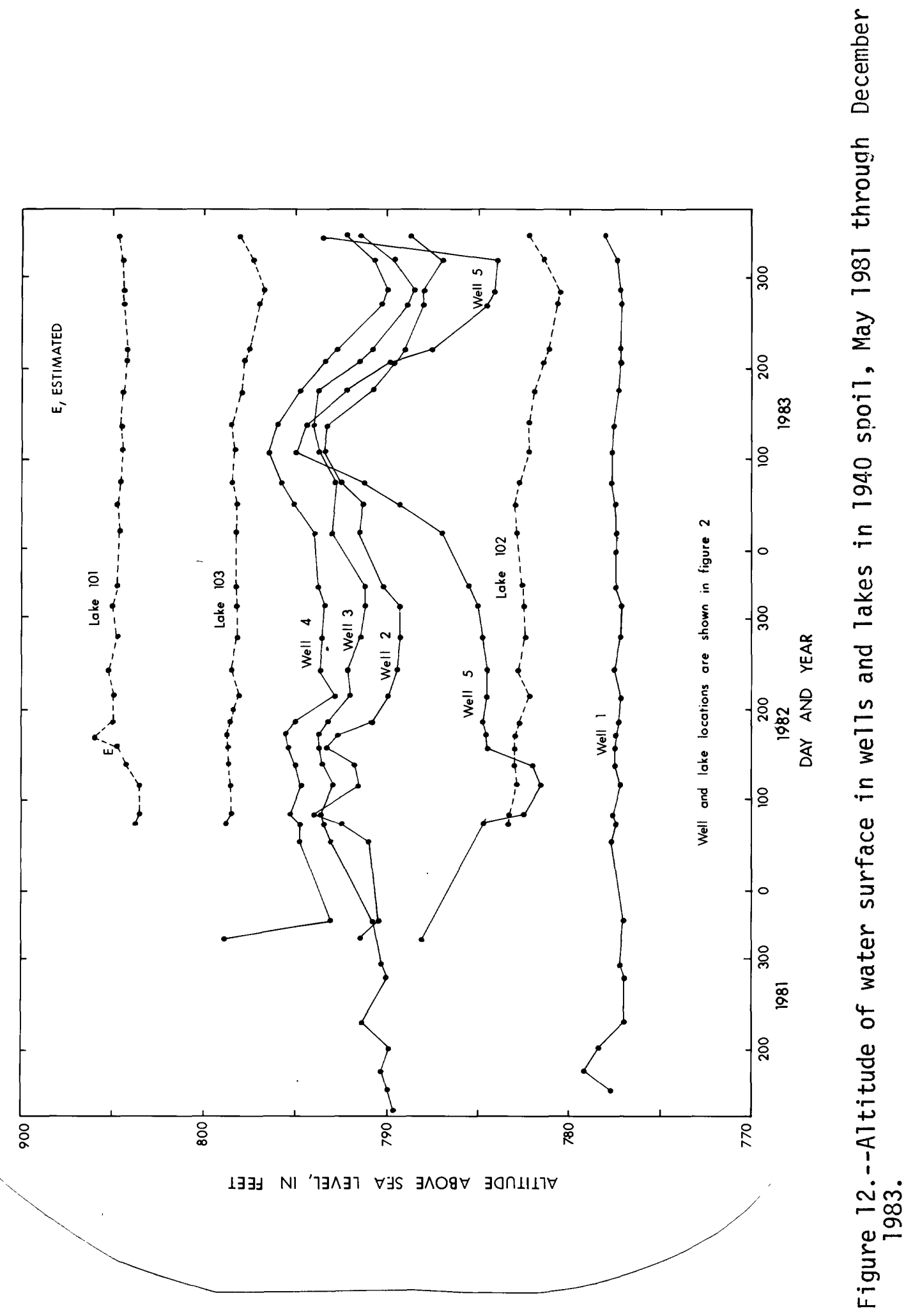




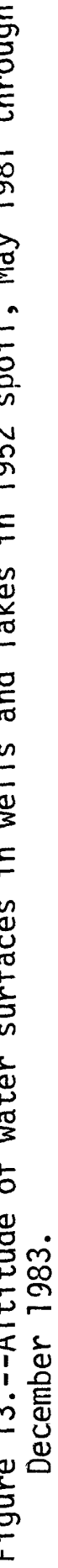




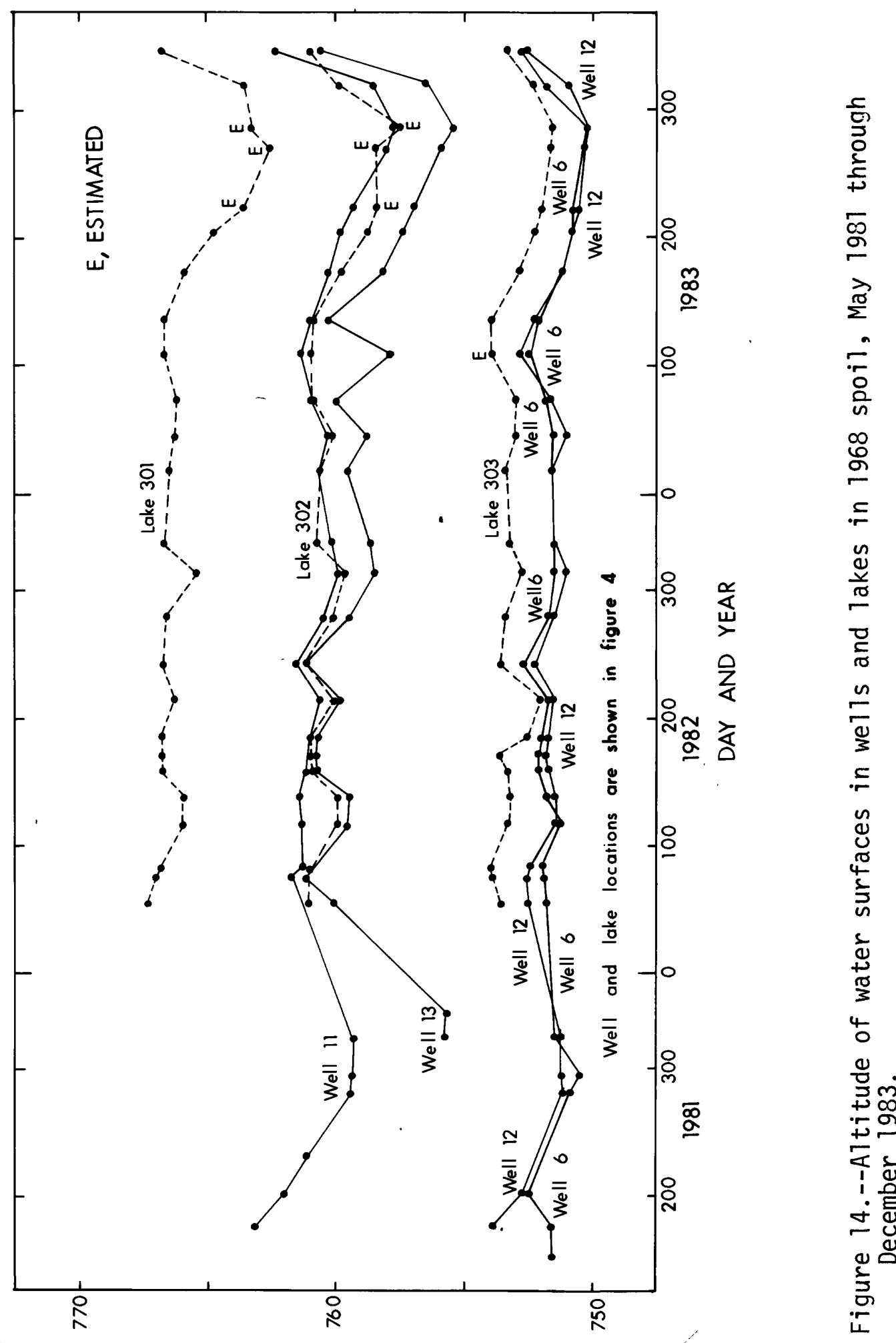

1 
The general geochemical processes that affect the ground-water quality in the study area usually begin with the dissolution of carbonate minerals or the oxidation of pyrite, or both. In a near-surface environment, carbon dioxide gas $\left(\mathrm{CO}_{2}\right)$ from organic decay or the atmosphere reacts with water $\left(\mathrm{H}_{2} \mathrm{O}\right)$ :

$$
\mathrm{CO}_{2}+\mathrm{H}_{2} \mathrm{O} \rightleftharpoons \mathrm{H}_{2} \mathrm{CO}_{3}
$$

the resulting carbonic acid $\left(\mathrm{H}_{2} \mathrm{CO}_{3}\right)$ dissociates

$$
\begin{aligned}
& \mathrm{H}_{2} \mathrm{CO}_{3} \rightleftharpoons \mathrm{H}^{+}+\mathrm{HCO}_{3}^{-} \text {and } \\
& \mathrm{HCO}_{3}^{-} \rightleftharpoons \mathrm{H}^{+}+\mathrm{CO}_{3}^{2-} \text {. }
\end{aligned}
$$

The effect of reactions 1,2 , and 3 is to produce a slighțly acidic environment conducive to the dissolution of calcite $\left(\mathrm{CaCO}_{3}\right)$ and dolomite $\left[\mathrm{CaMg}\left(\mathrm{CO}_{3}\right)_{2}\right]$ :

$$
\begin{gathered}
\mathrm{CaCO}_{3}+\mathrm{H}^{+} \rightleftharpoons \mathrm{Ca}^{+}+\mathrm{HCO}_{3}^{-} \text {and } \\
\mathrm{CaMg}\left(\mathrm{CO}_{3}\right)_{2}{ }^{+2 \mathrm{H}^{+}} \rightleftharpoons \mathrm{Ca}^{2}+\mathrm{Mg}^{+}+2 \mathrm{HCO}_{3}^{-} \text {. }
\end{gathered}
$$

Reactions 4 and 5 result in an increase in the concentrations of calcium ( $\mathrm{Ca}^{2+}$ ) and magnesium $\left(\mathrm{Mg}^{2}+\right)$, and an increase in bicarbonate $\left(\mathrm{HCO}_{3}{ }^{-}\right)$concentration.

If pyrite $\left(\mathrm{FeS}_{2}\right)$ is present in an oxidizing environment, the acidity $\mathrm{H}^{+}$ concentration) of the water can be increased:

$$
4 \mathrm{FeS}_{2}+15 \mathrm{O}_{2}+14 \mathrm{H}_{2} \mathrm{O} \rightleftharpoons 4 \mathrm{Fe}(\mathrm{OH})_{3}+8 \mathrm{SO}_{4}{ }^{2-}+16 \mathrm{H}^{+} \text {. }
$$

The iron compounds formed by reaction 6 can be iron hydroxide $\left[\mathrm{Fe}(\mathrm{OH})_{3}\right]$ as shown or iron oxyhydroxide $[\mathrm{FeO}(\mathrm{OH})]$ (goethite). The sulfate $\left(\mathrm{SO}_{4}{ }^{2-}\right.$ ) produced either remains in solution or precipitates, probably as calcium sulfate $\left(\mathrm{CaSO}_{4}\right)$. The $\mathrm{H}^{+}$produced increases the acidity and promotes the dissolution of carbonate minerals, if present, as in reactions 4 and 5 . The carbonate dissolution results in a decrease in $\mathrm{H}^{+}$concentration.

The adsorption of $\mathrm{Ca}^{2+}$ and $\mathrm{Mg}^{2+}$ and the release of sodium ( $\mathrm{Na}^{+}$) by exchange reactions with clay minerals and organic materials results in decreased $\mathrm{Ca}^{2+}$ and $\mathrm{Mg}^{2+}$ concentrations and an increased $\mathrm{Na}^{+}$concentration. This process also results in additional carbonate-mineral dissolution, resulting in a decrease in $\mathrm{H}^{+}$concentration and an increase in $\mathrm{HCO}_{3}^{-}$concentration.

The geochemical processes that predominate in an area are dependent on the hydrologic and mineralogic conditions. Therefore, depending on local conditions, the ground water can be of a calcium magnesium bicarbonate, calcium magnesium sulfate, sodium bicarbonate, or sodium sulfate type. Although the initial reactions result in an increase in acidity, much of the acidity is buffered by dissolution of carbonate materials. 


\section{EFFECTS OF STRIP MINING ON WATER QUALITY OF HIGH-WALL LAKES AND AQUIFERS}

Water from high-wall lakes and aquifers in the study area had dissolved-solids concentrations several orders of magnitude greater than precipitation. Precipitation at Ashland (45 miles south of the study area) had a dissolved-solids concentration of about 7 milligrams per liter. Concentrations of specific constituents in precipitation also were determined (table 5).

Dissolved-solids concentrations in water from three high-wall lakes ranged from 1,090 to 2,410 milligrams per liter, and had a median value of 2,059 milligrams per liter (table 6). The water generally was a calcium magnesium sulfate type (fig. 15).

Concentrations of dissolved-solids in water from the glacial drift ranged from 239 to 1,280 milligrams per liter, and had a median value of 559 milligrams per liter (table 7). The water generally was either a calcium magnesium bicarbonate or calcium magnesium sulfate type (fig. 16).

Dissolved-solids concentrations in water from bedrock ranged from 580 to 883 milligrams per liter and had a median value of 775.5 milligrams per liter (table 8). The water generally was either a sodium bicarbonate or calcium bicarbonate type (see fig. 16).

Concentrations of dissolved-solids in water from wells in or near spoil ranged from 1,890 to 4,660 milligrams per liter, and had a median value of 2,860 milligrams per liter (table 9). The water generally was a calcium magnesium sulfate type (see fig. 15), which was similar to water from high-wall lakes and similar to some of the water in the glacial drift. Water from wells completed in or near spoil was more uniform in composition than water from wells completed in glacial drift or bedrock, as shown by the closer grouping of ion-percentage values of water from spoil (see figs. 15 and 16).

Water from wells completed in or near spoil had greater median concentrations of many ions than water from other wells completed in the glacial drift or bedrock (table 10.) In water from wells completed in or near spoil, the median concentration of calcium was 5 times greater, magnesium 6 times greater, sulfate 24 times greater, iron 19 times greater, and manganese 15 times greater than in water from wells completed in glacial drift. The median concentrations of potassium and chloride were smaller in water from wells completed in or near spoil than in water from wells completed in glacial drift.

Water from wells completed in or near spoil also had greater median concentrations of many ions than water from wells completed in the bedrock. In water from wells completed in or near spoil, the median concentration of calcium was 45 times greater, magnesium 22 times greater, sulfate 16 times greater, iron 242 times greater, and manganese 47 times greater than in water from wells completed in bedrock. In contrast, the median concentrations of sodium, potassium, and chloride were smaller in water from wells completed in or near spoil than in water from wells completed in bedrock. 
Table 5.--Average chemical composition of precipitation at Ashland, December 1981 to Apri1 1982

\begin{tabular}{ll}
\hline $\begin{array}{l}\text { Property or } \\
\text { constituent }\end{array}$ & Quantity or concentration \\
\hline pH, in units & 4.5 \\
Calcium & 0.30 \\
Magnesium & 0.06 \\
Sodium & 0.11 \\
Potassium & 0.05 \\
Bicarbonate & 2.0 \\
Sulfate & 2.44 \\
Chloride & 0.22 \\
Ammonia & 0.27 \\
Nitrate & 1.30 \\
Phosphate & Less than 0.003 \\
\hline
\end{tabular}

IIn milligrams per liter, unless otherwise noted. Averages are weighted by volume for 20 weeks, except $\mathrm{pH}$ which is for 7 months, beginning during November 1981. From G. S. Henderson (Columbia, University of Missouri, written commun., 1983).

${ }^{2}$ Estimated from data compiled by Freeze and Cherry (1979, p. 239). 


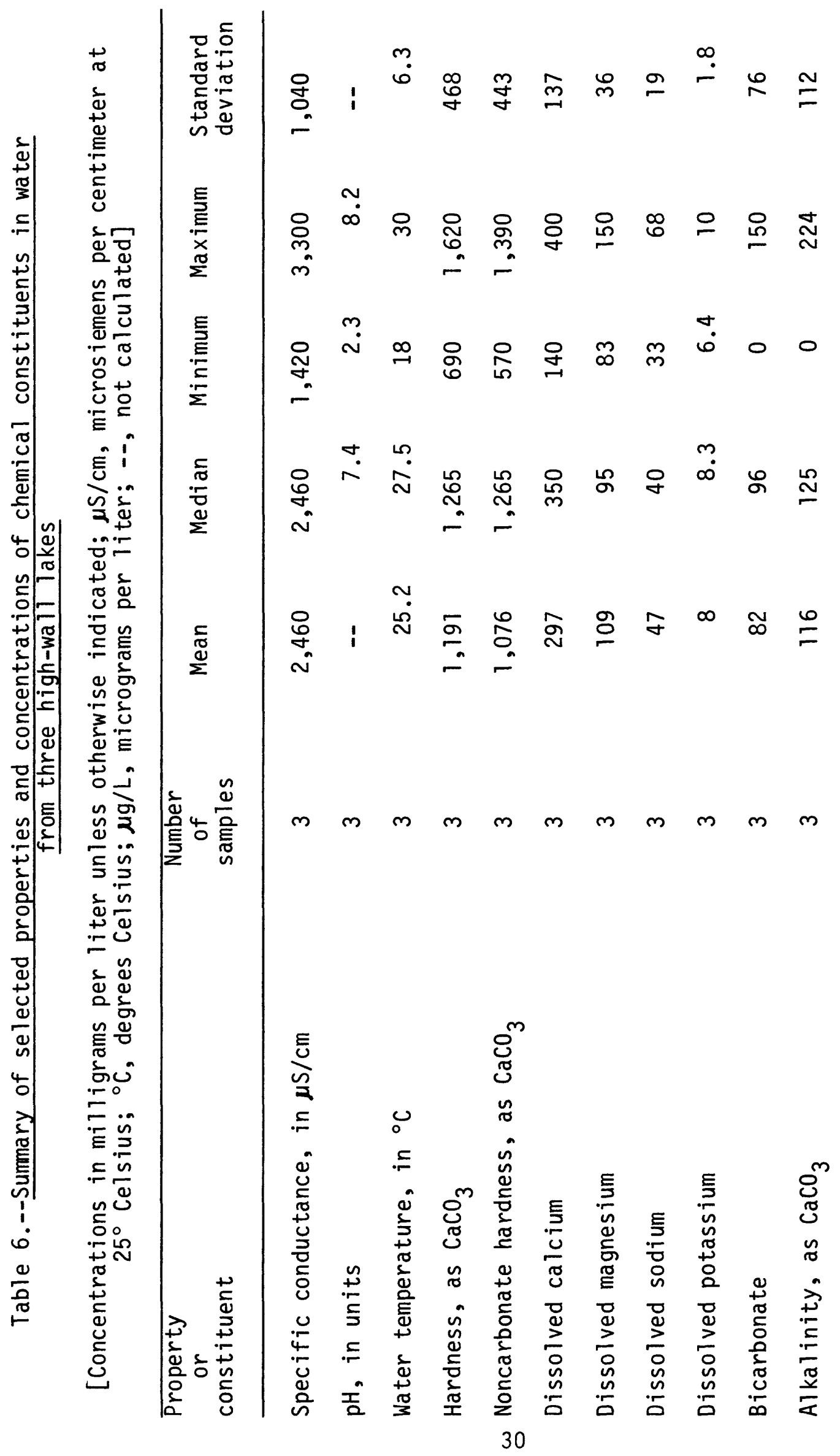




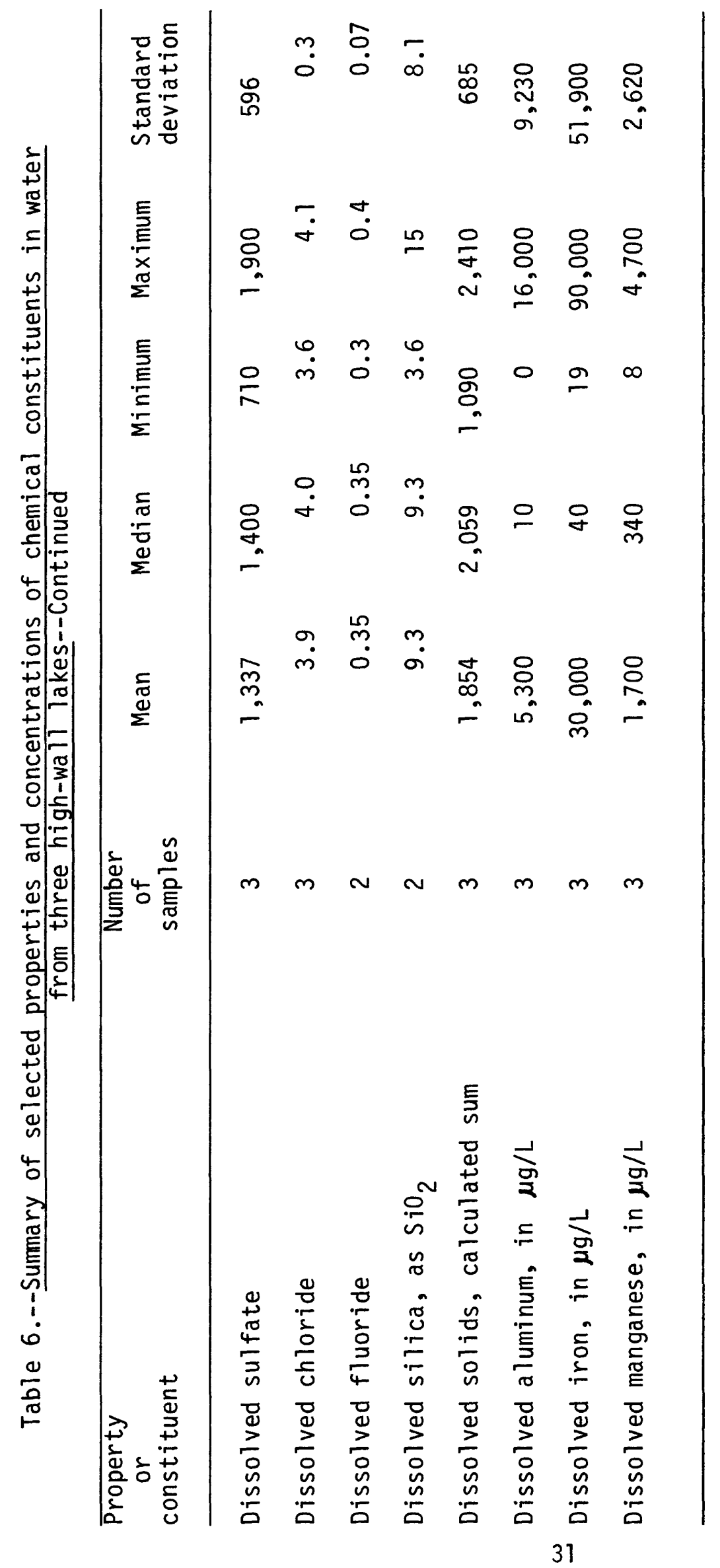




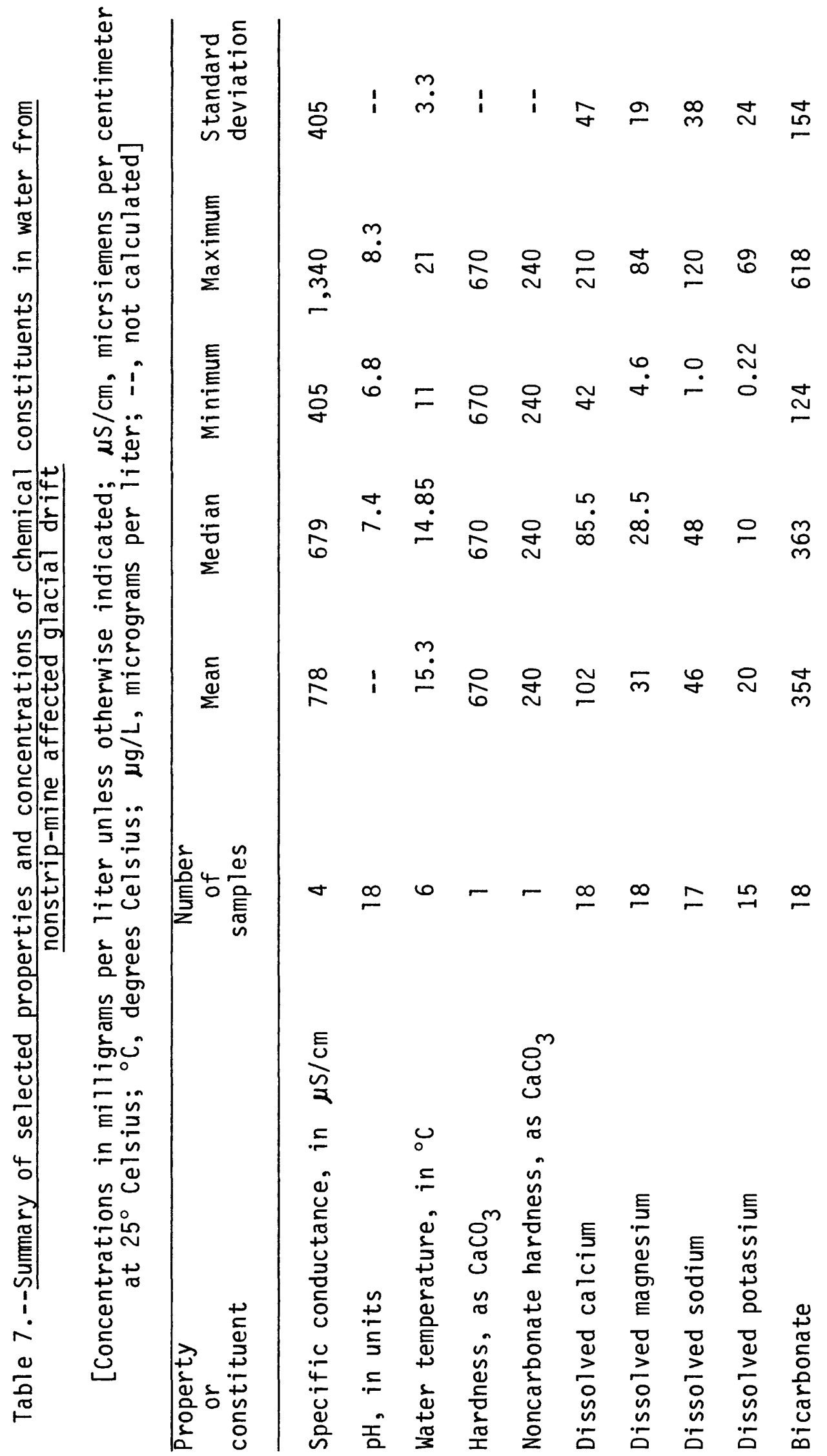




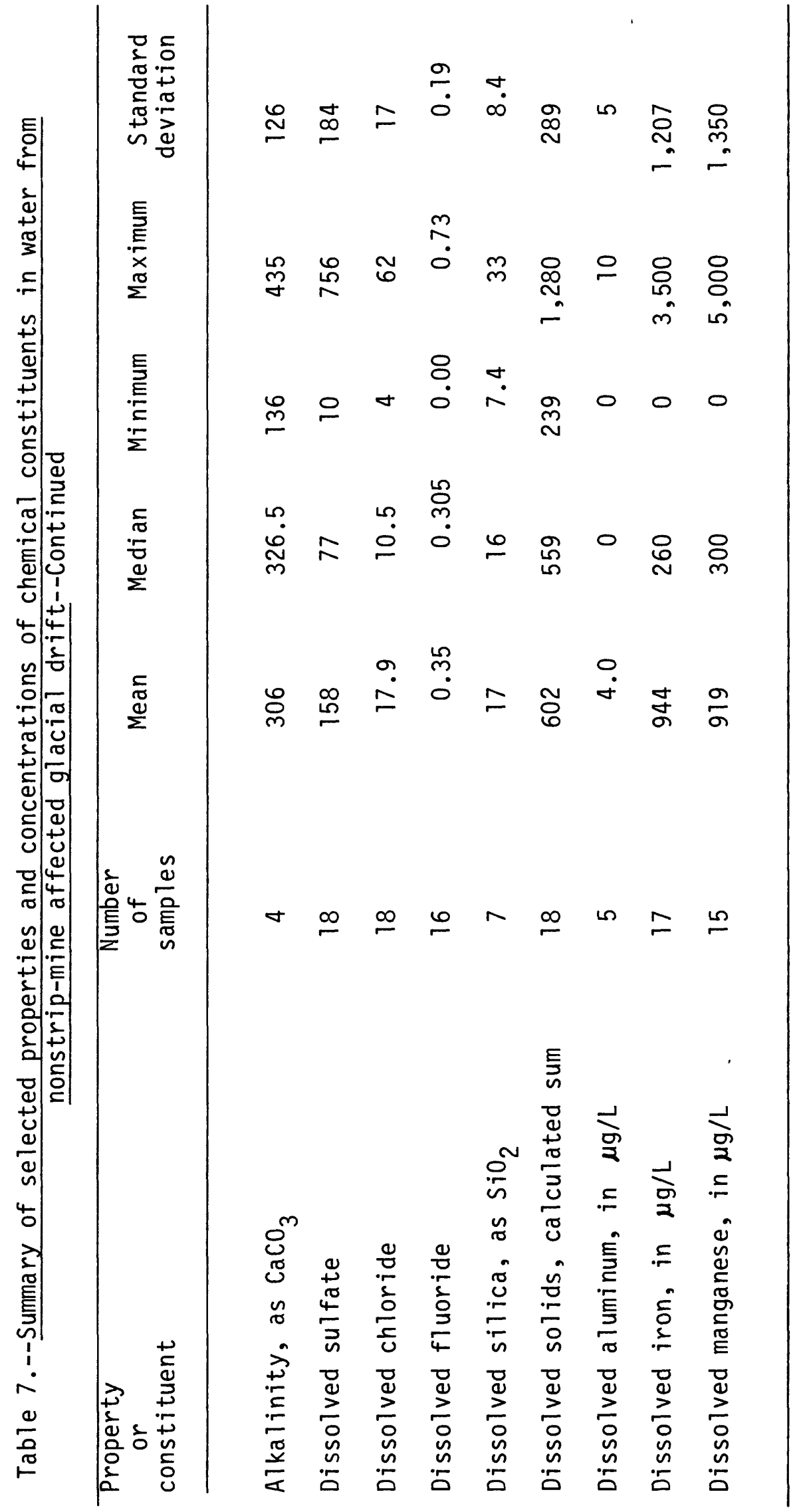




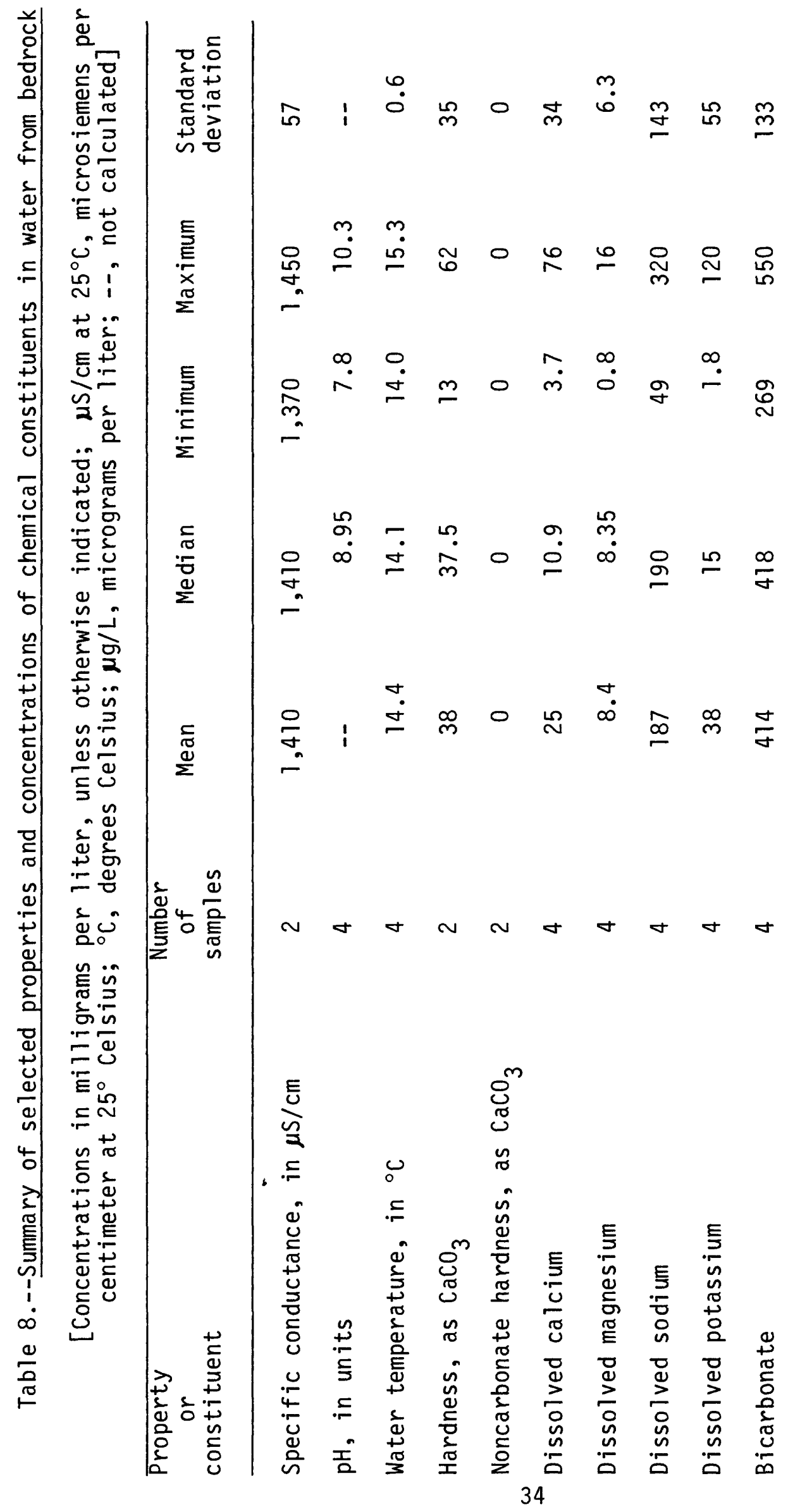




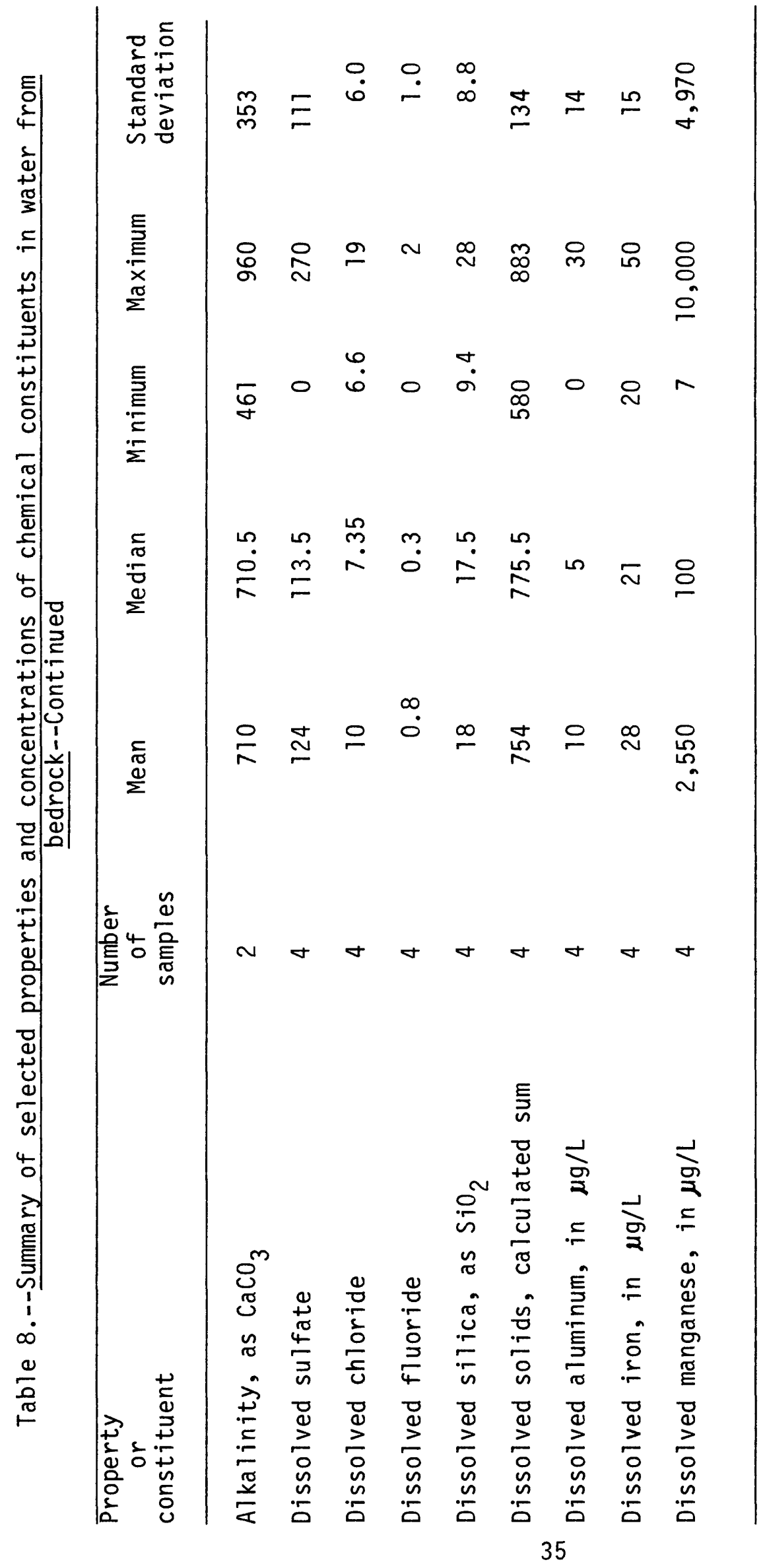




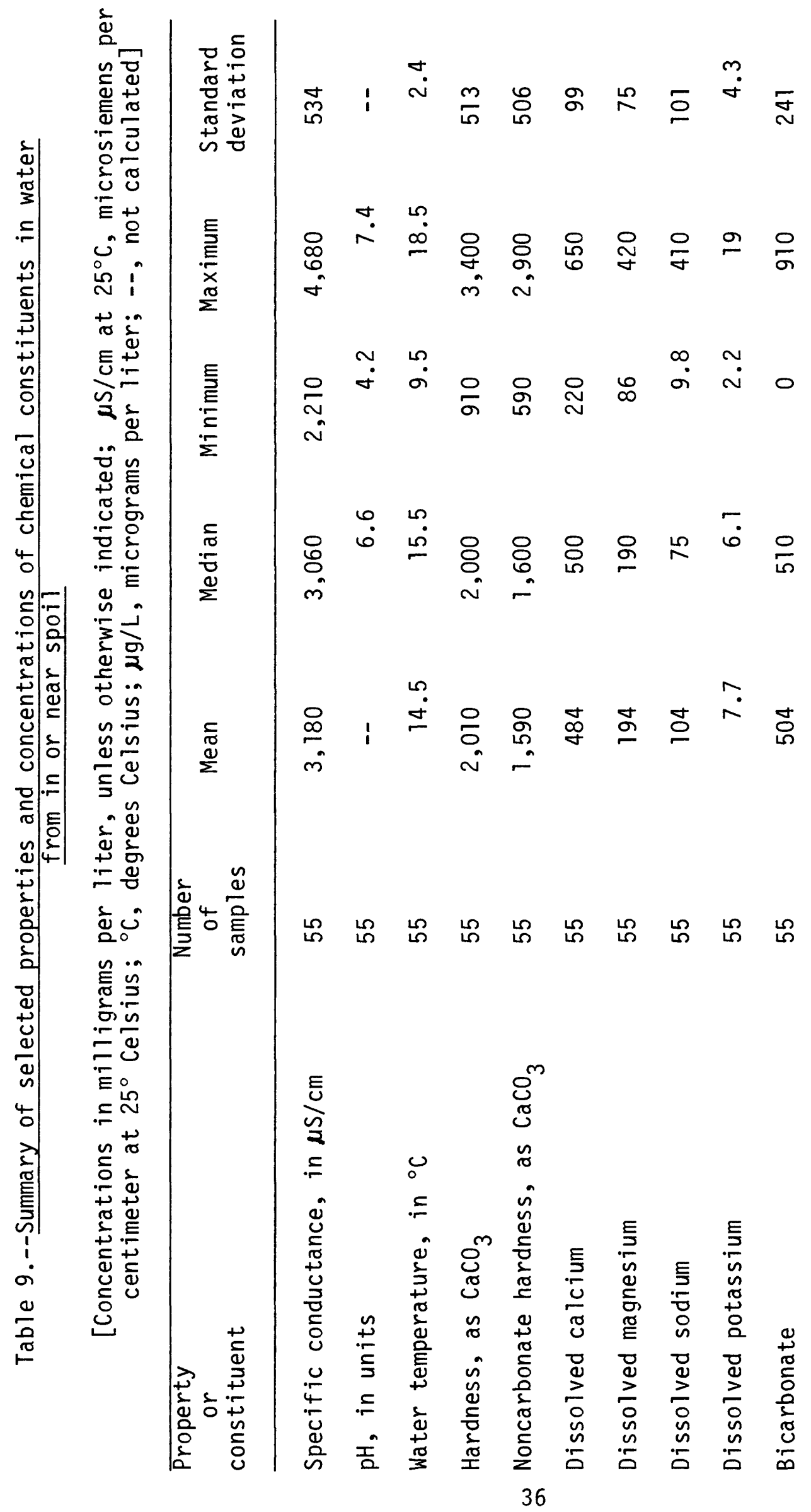




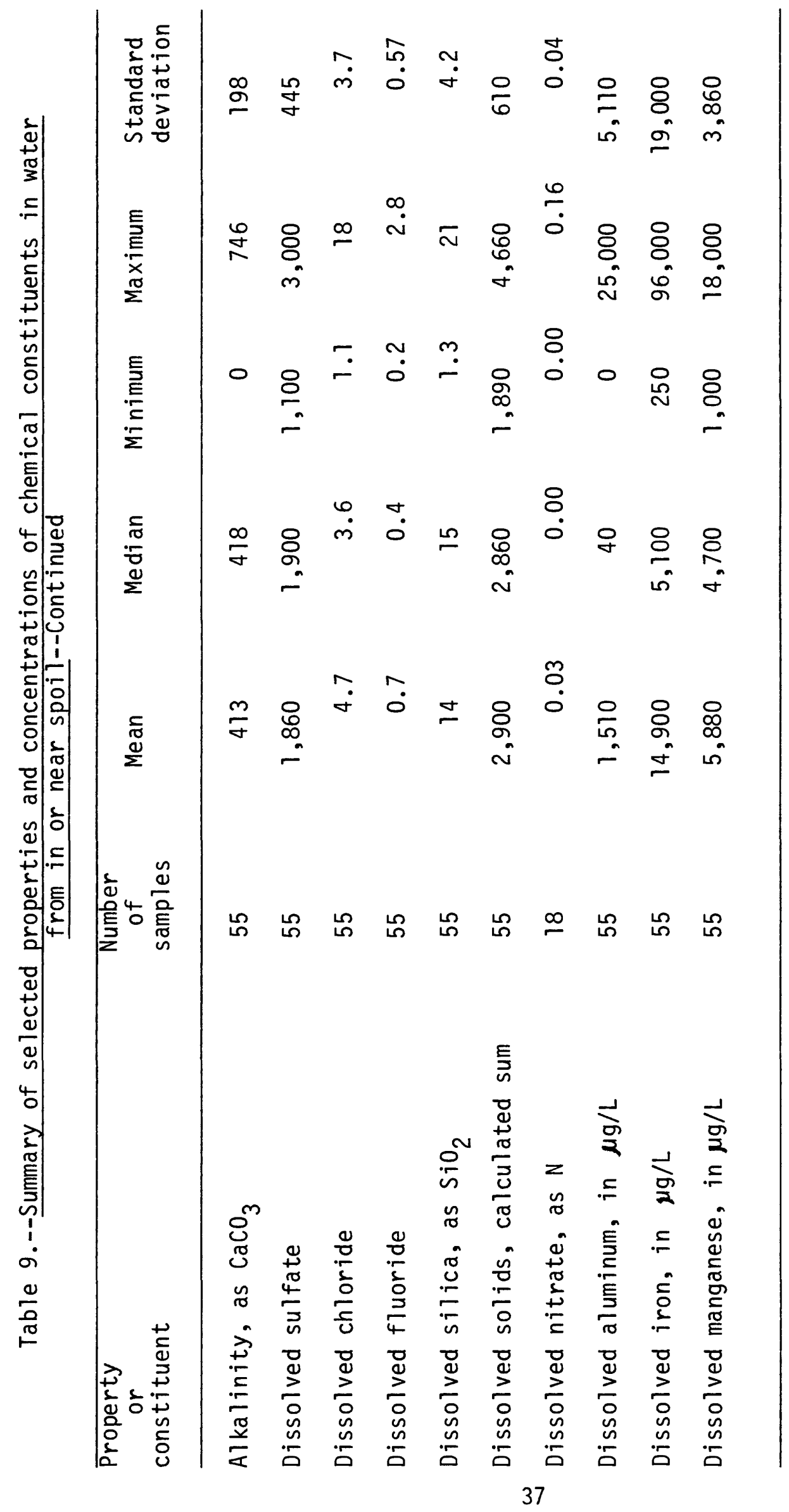


Table 10.--Comparison of medians of properties and selected chemical constituents in precipitation, high-wall lake water, and well water from glacial drift, bedrock, and in or near spoil

[Results reported in milligrams per liter unless otherwise indicated; $\mu \mathrm{g} / \mathrm{L}$, micrograms per liter --, no data]

\begin{tabular}{lccccc}
\hline $\begin{array}{l}\text { Property } \\
\text { or } \\
\text { constituent }\end{array}$ & $\begin{array}{c}\text { Precipi } \\
\text { tation }\end{array}$ & $\begin{array}{c}\text { High-wall } \\
\text { lakes }\end{array}$ & $\begin{array}{c}\text { Glacial } \\
\text { drift }\end{array}$ & Bedrock & $\begin{array}{c}\text { In or near } \\
\text { spoil }\end{array}$ \\
\hline pH, in units & 4.5 & 7.4 & 7.4 & 8.95 & 6.6 \\
Dissolved calcium & 0.30 & 350 & 85.5 & 10.9 & 500 \\
Dissolved magnesium & 0.06 & 95 & 28.5 & 8.35 & 190 \\
Dissolved sodium & 0.11 & 40 & 48 & 190 & 75 \\
Dissolved potassium & 0.05 & 8.3 & 10 & 15 & 6.1 \\
Bicarbonate & 2.0 & 95 & 363 & 418 & 510 \\
Dissolved sulfate & 2.44 & 1,400 & 77 & 113.5 & 1,900 \\
Dissolved chloride & 0.22 & 4.0 & 10.5 & 7.35 & 3.6 \\
Dissolved silica, as $\mathrm{Si}{ }_{2}$ & -- & 9.3 & 16 & 17.5 & 15 \\
Dissolved solids & 7 & 2,059 & 559 & 775.5 & 2,860 \\
Dissolved iron, in $\mu \mathrm{Mg} / \mathrm{L}$ & -- & 40 & 260 & 21 & 5,100 \\
Dissolved manganese, in $\mu \mathrm{g} / \mathrm{L}$ & -- & 340 & 300 & 100 & 4,700 \\
& & & & & \\
\hline
\end{tabular}

${ }^{7}$ Values for precipitation are volume-weighted means (see table 5). 


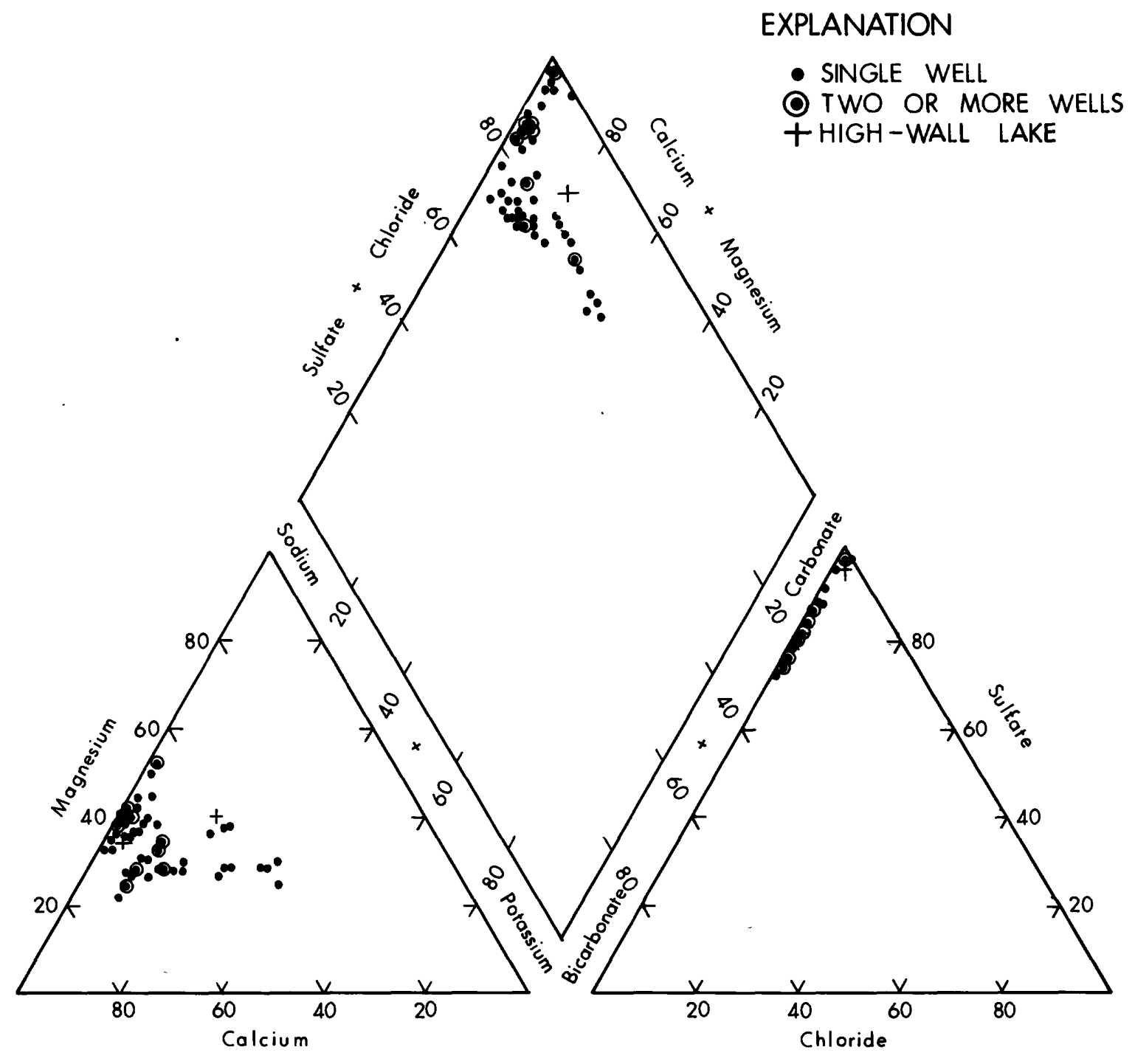

PERCENT OF TOTAL MILLIEQUIVALENTS PER LITER

Figure 15.--Major ions in water from 14 wells (55 analyses) completed in or near spoil and 3 high-wall lakes in or near spoil. 


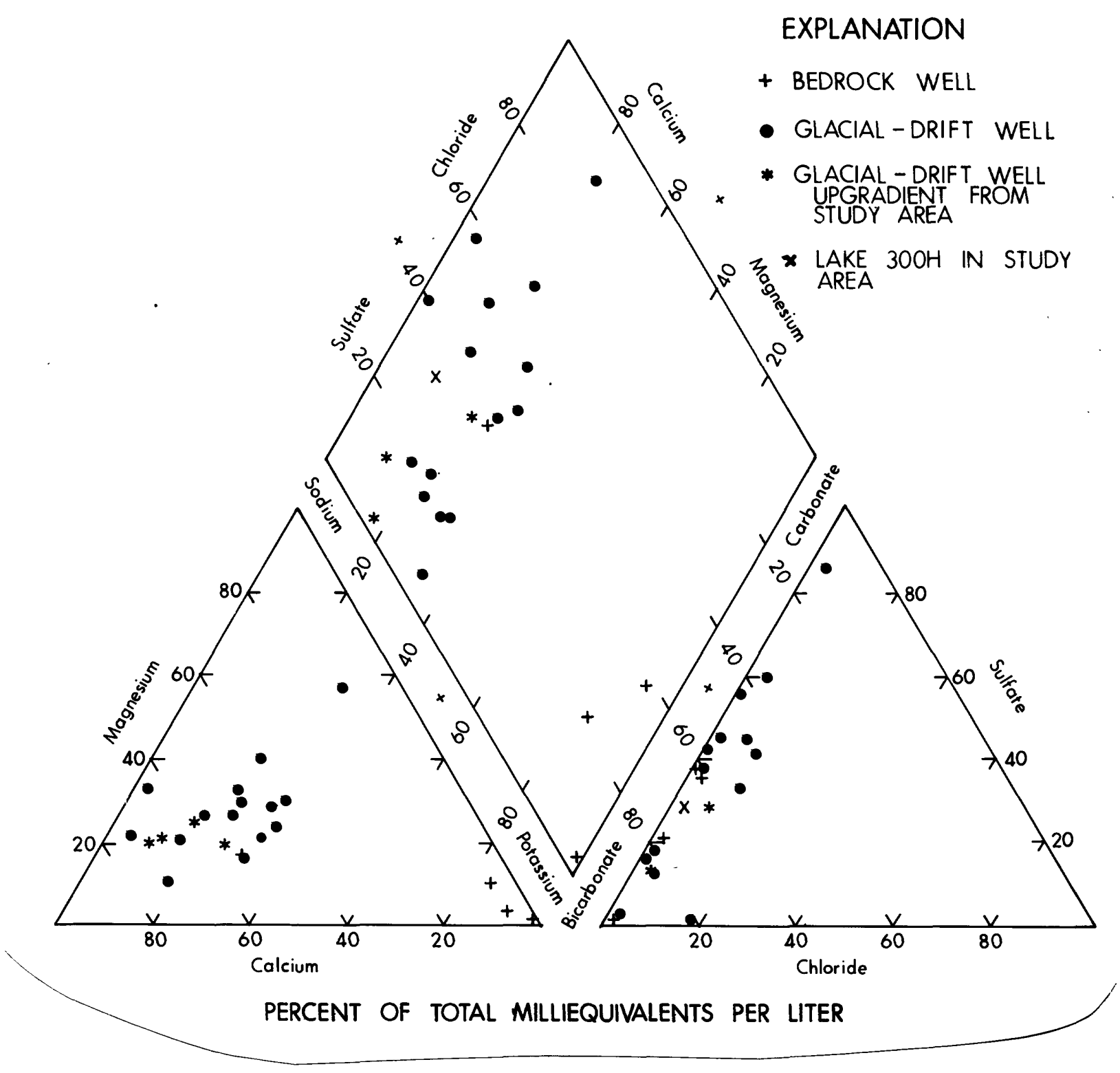

Figure 16.--Major ions in water from 4 wells comnleted in bedrock, 18 wells completed in glacial drift, and 1 lake in glacial drift, not affected by strip mining. 
The median $\mathrm{pH}$ of water from in or near spoil was 6.6 , which was smaller than the median $\mathrm{pH}$ of water from glacial drift (7.4) and the median $\mathrm{pH}$ of water from bedrock (8.95). The smaller $\mathrm{pH}$ in water from in or near spoil probably was caused by sulfuric acid produced from pyrite oxidation, although carbonate reactions probably neutralize most of the acidity that is produced. The $\mathrm{pH}$ of water from the bedrock was somewhat alkaline and probably results from carbonate reactions in a hydrologic system closed to the atmosphere (G. G. Seifert, University of Missouri, written commun., 1981; Freeze and Cherry, 1979, p. 108-112 and 256-257).

Changes in $\mathrm{pH}$ and selected chemical constituents along flow paths were examined in each spoil area. In 1940 spoil, wells 2 and 3 are downgradient from well 4 (see fig. 10) and water from wells 2 and 3 generally had larger concentrations of magnesium, sulfate, and dissolved solids (fig. 17). In 1952 spoil, the concentration of manganese increased downgradient, but $\mathrm{pH}$ and concentrations of calcium, magnesium, and dissolved solids decreased downgradient (see figs. 11 and 18). Concentrations in water from well 8 generally did not conform to these trends, possibly due to different solute sources or mixing with water from the underlying bedrock. In 1968 spoil, well 12 was downgradient from wells 11 and 13 (see fig. 11 ), and water from well 12 generally had larger concentrations of calcium, magnesium, iron, manganese, sulfate, and dissolved solids and had a smaller $\mathrm{pH}$ value (fig. 19).

The downgradient trends in water quality were similar for the 1940 and 1968 spoil areas, but different for the 1952 spoil. The lack of a similar trend in water-quality changes for all three spoil areas indicates different solute sources or different sources of recharge to the spoils. Because mineralogical changes were not discerned, the source of recharge probably was the main contributing factor.

Statistical comparisons were used to determine if the general water quality differed between the 1940-, 1952- and 1968-spoil areas. Because the data generally were not normally distributed, the nonparametric Duncan multiple-range test on the means of the ranks of the data was used. Statistical summaries of data by spoil area are given in the "Supplemental Data" section at the back of the report.

Comparisons of mean rank values of $\mathrm{pH}$, and concentrations of calcium, magnesium, iron, manganese, sulfate, chloride, and dissolved solids are shown in table 11. For each property or constituent shown in the table, spoil-area mean designated by the same arbitrary letter are not different at the 95-percent level of confidence. For example, the mean-rank $\mathrm{pH}$ values of the 1940 and 1952 spoil were not significantly different, as indicated by the letter designation of B. However, they were significantly different from the mean-rank pH of 1968 spoil, indicated by $A$. If the letter designation for a mean includes both $A$ and $B$, as for manganese from the 1940 spoil, then that mean was not significantly different from the means of either the A or B classification.

The 1940 and 1952 spoil mean-rank values were not significantly different for $\mathrm{pH}$, calcium, iron, manganese, and dissolved solids and were significantly different for magnesium, sulfate, and chloride. The 1952 and 1968 spoil values were not significantly different for iron, but were significantly different for 
pH, calcium, magnesium, manganese, sulfate, chloride, and dissolved solids. However, the 1940- and 1968-spoil values were not significantly different for the listed constituents, except calcium and pH. Therefore, although differences in general water quality existed among the spoil areas, these differences cannot be attributed to age of the spoil. For the spoil areas studied, the major changes in water quality occurred within 12 years or less and have persisted for more than 40 years.

Chemical-equilibrium relationships were determined using the computer program WATEQF (Plummer and others, 1976). WATEQF calculates the degree of saturation of the water from a water-quality analysis with respect to given minerals. The degree of saturation is expressed by the saturation index, which is the logarithm of the ratio of the ion-activity product to the temperature-corrected equilibrium constant (see "Supplemental Data" section at the back of report). Positive values of the saturation index indicate supersaturation, negative values indicate undersaturation, and values of about zero indicate saturation or equilibrium.

To evaluate the saturation index for minerals involved in oxidation or reduction reactions, the oxidation potential (Eh) needs to be determined. For water from wells $N, P, Q$, and $R$ (see fig. 1), which were completed in either glacial drift or bedrock, the Eh was determined by calomel electrode. These measured values range from 0.075 to 0.222 volt, which represent oxidizing conditions (table 12). The $\mathrm{Eh}$ of water from most other wells completed in either glacial drift or bedrock was assumed to be 0.222 volt, based on the measured value from well $\mathrm{N}$.

For water from wells completed in or near spoil (wells 1-15), the Eh was determined in WATEQF from the ratio of the concentrations of sulfate to sulfide. The odor of hydrogen sulfide gas was detected in water from all wells in or near spoil and, because the odor is detectable in water containing small concentrations, the sulfide concentration was estimated to be 0.1 milligram per liter. The calculated Eh values ranged from -0.197 to 0.014 volt (see table 12), which generally indicates reducing conditions.

For water from wells $T, U$, and $V$, which were completed in glacial drift, and water from high-wall lakes, Eh was not determined or estimated. The value of 0.000 volt was used for these calculations in WATEQF.

Because most Eh values used for equilibrium calculations were estimated, the results of calculations for all minerals involved in oxidation or reduction reactions need to be considered with caution. However, the results can be useful to discern general equilibrium conditions and trends. The minerals of interest that are involved in oxidation or reduction reactions are amorphous ferric hydroxide, goethite, pyrite, and siderite.

The saturation indices for water from precipitation, high-wall lakes, and wells in the study area are included in the "Supplemental Data" section at the back of this report. A summary of the saturation indices is given in table 13. Water from all sources, except precipitation, generally was near equilibrium with respect to calcite, dolomite, and quartz; water from all sources, except wells completed in or near spoil, was undersaturated with respect to gypsum. 
Table 11.--Comparison of means of property or constituent concentration in water from spoil of different ages

\begin{tabular}{lccc}
\hline $\begin{array}{l}\text { Property } \\
\text { or } \\
\text { constituent }\end{array}$ & $\begin{array}{c}\text { Mean-rank comparison letter } \\
(1940 \text { spoil }\end{array}$ & $\begin{array}{c}1952 \text { spoil } \\
(25 \text { samples })\end{array}$ & $\begin{array}{c}1968 \text { spoil } \\
(12 \text { samples })\end{array}$ \\
\hline pH & B & B & A \\
Dissolved solids & A,B & A & B \\
Dissolved calcium & A & A & B \\
Dissolved magnesium & B & A & B \\
Dissolved iron & A & A & A \\
Dissolved manganese & A,B & A & B \\
Dissolved sulfate & B & A & B \\
Dissolved chloride & A & B & A \\
\hline
\end{tabular}

${ }^{1}$ Mean-rank values with the same letter symbol underneath are not significantly different at the 95 percent level of confidence as determined by the Duncan multiple-range test on ranks. 


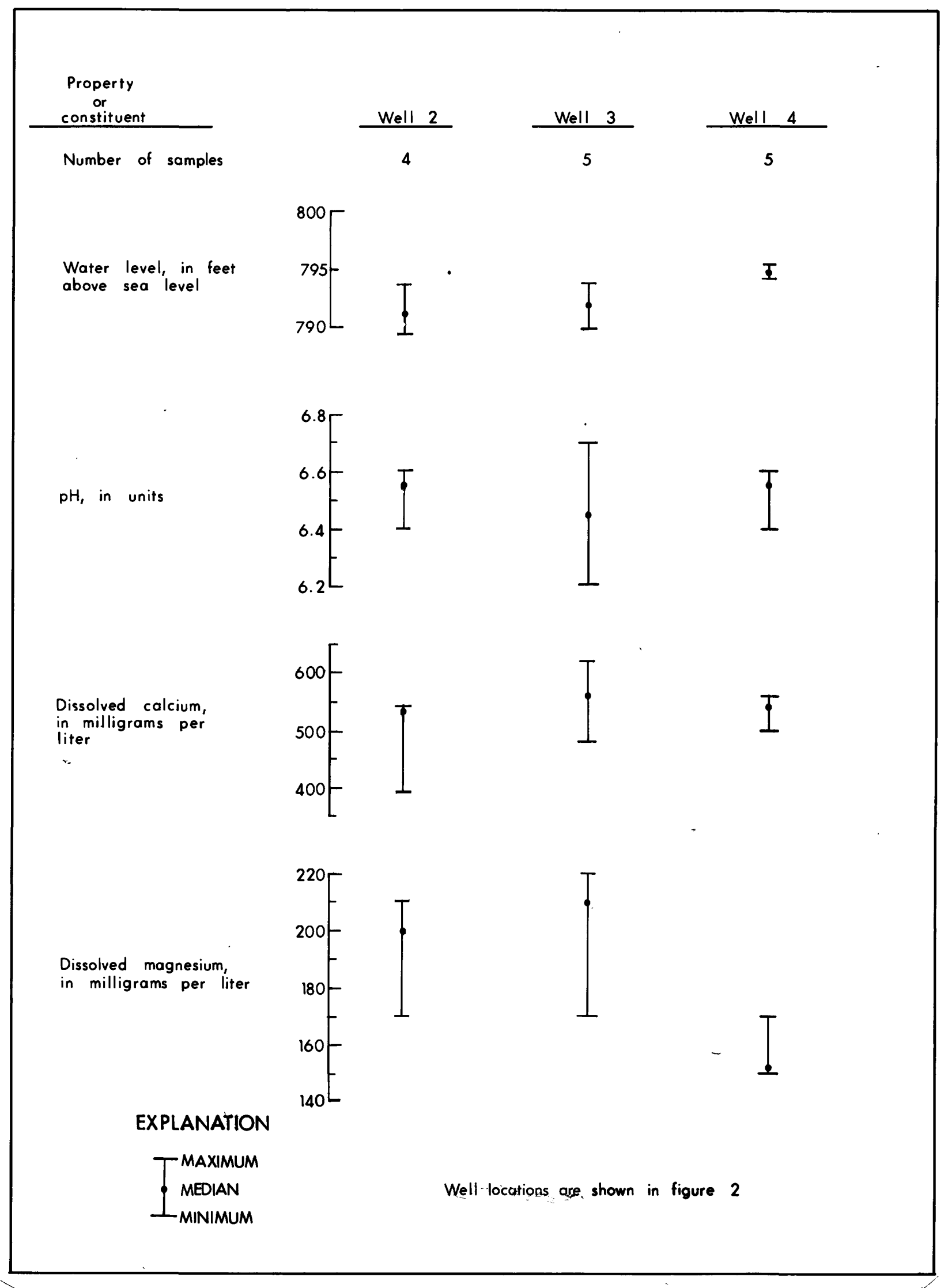

Figure 17.--Ranges and medians of water levels, $\mathrm{pH}$, and selected chemical constituents in water from three wells completed in 1940 spoil. 


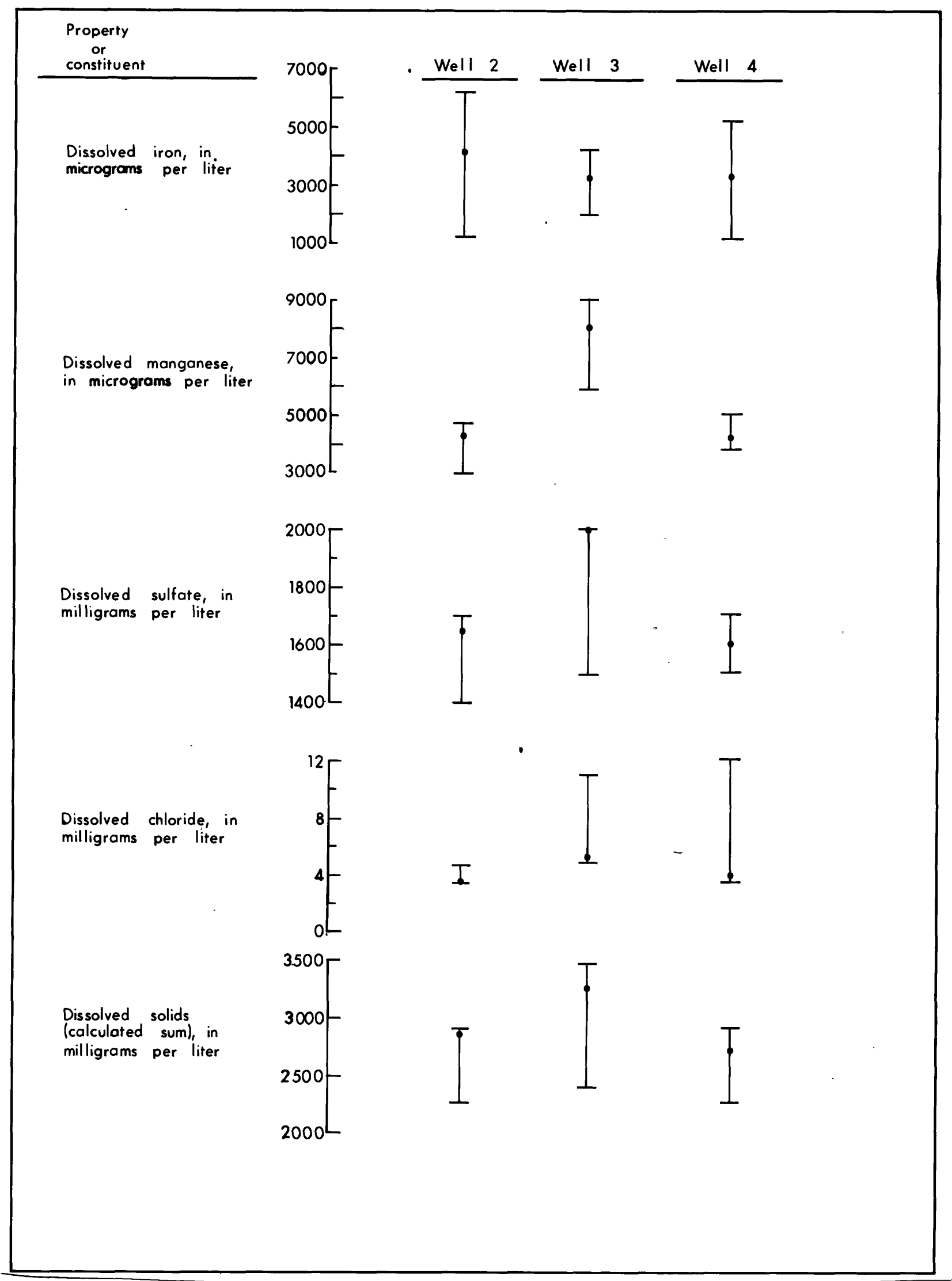

Figure 17.--Ranges and medians of water levels, $\mathrm{pH}$, and selected chemical constituents in water from three wells completed in 1940 spoil--Continued. 


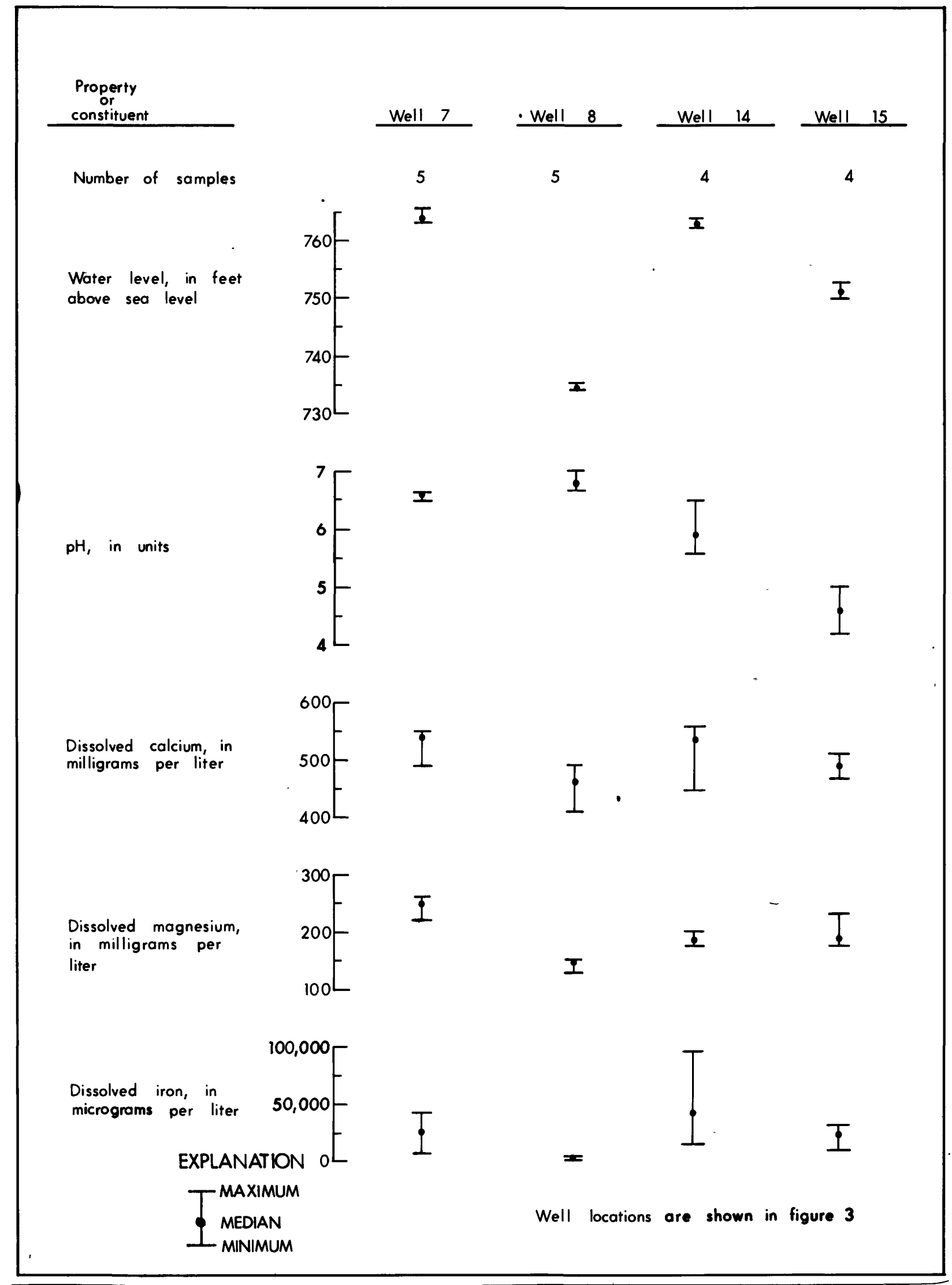

Figure 18.--Ranges and medians of water levels, $\mathrm{pH}$, and selected chemical constituents in water from four wells completed in 1952 spoil. 


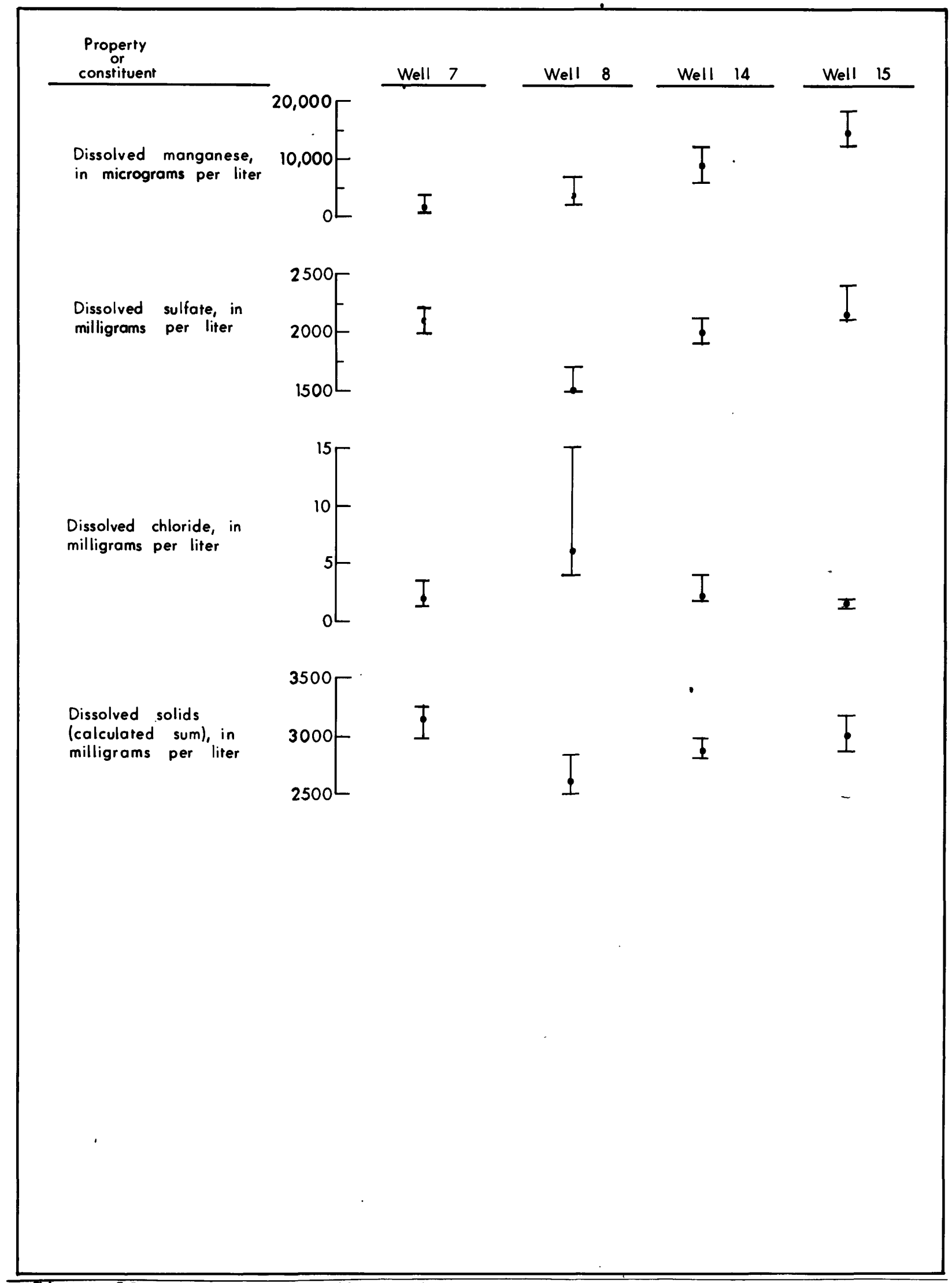

Figure 18.--Ranges and medians of water levels, $\mathrm{pH}$, and selected chemical constituents in water from four wells completed in 1952 spoil--Continued. 


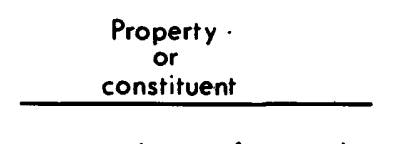

Number of samples

Water level, in feet
above sea level

pH, in units $6.6^{-}$

Dissolved calcium,
in milligrams 'per liter

Dissolved magnesium,
in milligrams per liter

Dissolved iron, in

micrograms per liter

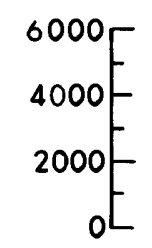

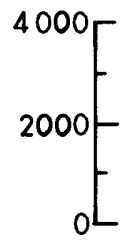

EXPLANATION

T MAXIMUM

MEDIAN

MINIMUM

O SINGLE VALUE o
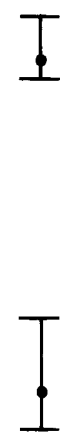

o

o

4

Well 13

3

$\bar{z}$

Iㄷ
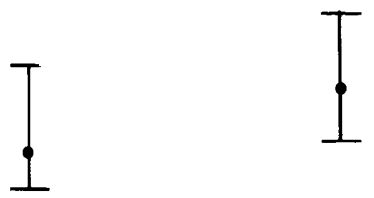

I

$=$

$=$

1

o

Well locations are shown in figure 4

Figure 19.--Ranges and medians of water levels, $\mathrm{pH}$, and selected chemical constituents in water from three wells completed in 1968 spoil. 


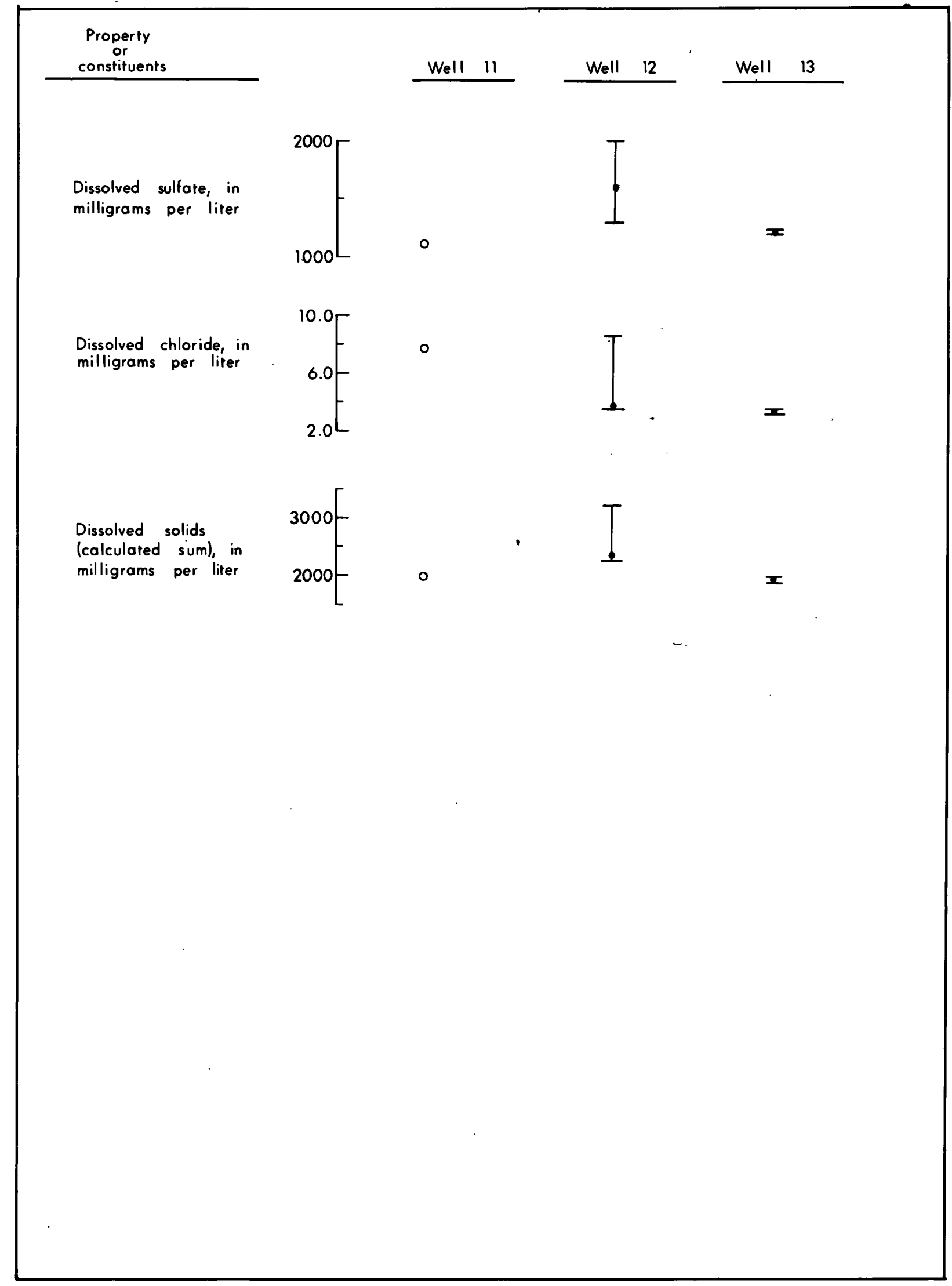

Figure 19.--Ranges and medians of water levels, pH, and selected chemical constituents in water from three wells completed in 1968 spoil--Continued. 
Table 12.--0xidation-potential (Eh) values used in chemical-equilibrium calculations

$[--$, not applicable $]$

\begin{tabular}{lll}
\hline Sample & Eh value, & Method of determining Eh \\
in volts
\end{tabular}

WELLS (figs. 1-4)

$1 \quad-0.155$ to -0.133

2

3

4

6

7

8

9

10

11

12

13

14

15

A

B

C

D

E

$F$

G

H

I

H

I

J

K

$L$

$M$

$N$
0
$P$
$Q$
$R$
-.146 to -.131

-.153 to -.118

-.145 to -.132

-.168 to -.158

-.149 to -.122

-.173 to -.144

-.177 to -.123

-.167 to -.136

$-.174$

-.197 to -.154

-.191 to -.168

-.138 to -.068

-.348 to .025

.222

.222

.222

.222

.222

.222

.222

.222

.222

.222

.222

.222

.222

.222

.222

.222

.222

.142

.075

.109
Sulfate-to-sulfide-ion ratiol

Do.

Do.

Do.

Do.

Do.

Do.

Do.

Do.

Do.

Do.

Do.

Do.

Do.

Assigned 2

Do.

Do.

Do.

Do.

Do.

Do.

Do.

Do.

Do.

Do.

Do.

Do.

Do.

Do.

Measured by calomel electrode 3 Assigned ${ }^{2}$

Measured by calomel electrode ${ }^{3}$

Do.

Do. 
Table 12.--0xidation-potential (Eh) values used in chemical-equilibrium calculations--Continued

\begin{tabular}{|c|c|c|}
\hline $\begin{array}{l}\text { Sample } \\
\text { source }\end{array}$ & $\begin{array}{l}\text { Eh value, } \\
\text { in volts }\end{array}$ & Method of determining Eh \\
\hline \multicolumn{3}{|c|}{ WELLS (figs. 1-4)--continued } \\
\hline $\begin{array}{l}S \\
T \\
U \\
V\end{array}$ & $\begin{array}{c}0.222 \\
-- \\
-- \\
--\end{array}$ & $\begin{array}{c}\text { Assigned }^{2} \\
\text { Oxidation or reduction ignored } \\
\text { Do. } \\
\text { Do. }\end{array}$ \\
\hline \multicolumn{3}{|c|}{ LAKES (figs. 2-4) } \\
\hline $\begin{array}{l}101 \\
201 \\
301 \\
300 \mathrm{H}\end{array}$ & $\begin{array}{l}-- \\
-- \\
--\end{array}$ & $\begin{array}{c}\text { Oxidation or reduction ignored } \\
\text { Do. } \\
\text { Do. } \\
\text { Do. }\end{array}$ \\
\hline \multicolumn{3}{|c|}{ PRECIPITATION (table 5) } \\
\hline Ashland & -- & Oxidation or reduction ignored \\
\hline
\end{tabular}

1 Sulfide-ion concentration assumed to be 0.1 milligram per liter.

2 Assigned the same value as measured for well $\mathrm{N}$.

3 From Seifert, 1982. 
Table 13.--Summary of saturation states in water from precipitation, high-wall lakes, and wells completed in glacial drift, bedrock, and in or near spoil

$[U$, undersaturated; E, equilibrium; S, supersaturation; --, not calculated]

\begin{tabular}{|c|c|c|c|c|c|}
\hline \multirow[b]{2}{*}{ Mineral } & \multicolumn{5}{|c|}{ General saturation state for water from indicated source 1} \\
\hline & Precipitation & $\begin{array}{l}\text { High-wa } 11 \\
\text { lakes }\end{array}$ & $\begin{array}{c}\text { Glacial } \\
\text { drift }\end{array}$ & $\begin{array}{l}\text { Wells } \\
\text { Bedrock }\end{array}$ & $\begin{array}{c}\text { In or near } \\
\text { spoil }\end{array}$ \\
\hline $\begin{array}{l}\text { Calcite } \\
\left(\mathrm{CaCO}_{3}\right)\end{array}$ & U & $E$ to $S$ & $\mathrm{E}$ & E to $S$ & $\begin{array}{c}E \\
\text { (except wells } \\
14 \text { and } 15 \text { ) }\end{array}$ \\
\hline $\begin{array}{l}\text { Dolomite } \\
\qquad\left[\mathrm{CaMg}\left(\mathrm{CO}_{3}\right)_{2}\right]\end{array}$ & U & $E$ to $S$ & $\underset{E}{N e a r}$ & E to $S$ & $\begin{array}{c}E \\
\text { (except wells } \\
14 \text { and } 15 \text { ) }\end{array}$ \\
\hline$\underset{\left(\mathrm{CaSO}_{4} \cdot 2 \mathrm{H}_{2} \mathrm{O}\right)}{\text { Gypsum }}$ & u & $U$ to $E$ & u & u & $\mathrm{E}$ \\
\hline $\begin{array}{l}\text { Amorphous } \\
\text { ferric hydroxid } \\
{\left[\mathrm{Fe}(\mathrm{OH})_{3}\right]}\end{array}$ & ide & $U$ to $S$ & $\mathrm{~s}$ & $E$ to $S$ & U \\
\hline $\begin{array}{l}\text { Goethite } \\
\qquad[\mathrm{FeO}(\mathrm{OH})]\end{array}$ & -- & $S$ & $S$ & $S$ & $\begin{array}{l}\text { E to S } \\
\text { (except well } \\
15 \text { ) }\end{array}$ \\
\hline $\begin{array}{l}\text { Siderite } \\
\left(\mathrm{FeCO}_{3}\right)\end{array}$ & -- & U & U & U & $U$ to $S$ \\
\hline $\begin{array}{l}\text { Pyrite } \\
\quad\left(\mathrm{FeS}_{2}\right)\end{array}$ & -- & -- & -- & -- & $S$ \\
\hline $\begin{array}{l}\text { Quartz } \\
\quad\left(\mathrm{SiO}_{2}\right)\end{array}$ & -- & $\mathrm{E}$ & $\mathrm{E}$ & $\mathrm{E}$ & $\mathrm{E}$ \\
\hline
\end{tabular}

${ }^{1}$ Saturation indices for individual water samples are in "Supplemental Data" section at back of report. 
Precipitation infiltrating through glacial drift, bedrock, or spoil would dissolve quartz and carbonate minerals, such as calcite and dolomite, until chemical equilibrium is attained. Precipitation infiltrating spoil also would dissolve gypsum or oxidize pyrite until equilibrium is attained or limiting reactants, such as oxygen, are consumed.

Water flowing from high-wall lakes, glacial drift, or bedrock through spoil would dissolve gypsum or oxidize pyrite until equilibrium is attained. Carbonate minerals also probably would be dissolved because they are more soluble at the lesser $\mathrm{pH}$ values in water from spoil.

Water from glacial drift and bedrock generally was undersaturated with respect to gypsum, whereas water in or near spoil generally was saturated with respect to gypsum. The difference in spoil could be attributed either to dissolution of freshly exposed gypsum or to oxidation of freshly exposed pyrite, or both. The exposure of the minerals probably resulted from disturbance of the glacial drift and bedrock overburden during mining because, during a long period, any exposed gypsum would have been dissolved in the chemically undersaturated environment and any exposed pyrite would have been oxidized in the generally oxidizing environment.

Mass-balance calculations using the computer program BALANCE (Parkhurst and others, 1982) determined the quantities of the principal minerals or other reactants that hypothetically would have dissolved or precipitated in the spoil (tables 14 and 15). The calculations are based on the change in concentration of the principal constituents in water moving into spoil from an outside source: namely, precipitation, high-wall lakes, glacial drift, or bedrock. The computer program BALANCE requires that the number of constituents equals the number of minerals or other reactants and that each constituent be present in at least one mineral or reactant.

For this study, the principal constituents are calcium, magnesium, carbon (present in water as carbonate, bicarbonate, carbon dioxide gas, and carbonic acid), sulfur (present in water mainly as sulfate), iron, and sodium. Two different sets of minerals and other reactants were used for all calculations, the difference being the mineral assumed to be the source of sulfate in water in spoil.

For the calculations in table 14, the source of sulfate was assumed to be pyrite. Considering all initial-water and spoil-water sources shown, the determined changes in water quality generally resulted from dissolution of calcite and dolomite, consumption of oxygen gas, release of carbon dioxide gas, dissolution of pyrite, and precipitation of goethite (or iron hydroxide). Ion exchange, which is the adsorption of calcium ions and subsequent release of sodium ions, occurred in all examples except for bedrock water flowing into spoil at wells 3 and 8 . At wells 3 and 8 , ion exchange probably was not occurring; more likely, the smaller sodium concentrations are caused by adsorption of sodium ions by organic materials in the spoil.

For the calculations in table 15, the source of sulfate was assumed to be gypsum. Considering all initial-water and spoil-water sources shown, the determined changes in water quality generally resulted from precipitation of calcite, dissolution of dolomite and gypsum, consumption of carbon dioxide gas, and the same ion-exchange reactions as described for the data in table 14. 


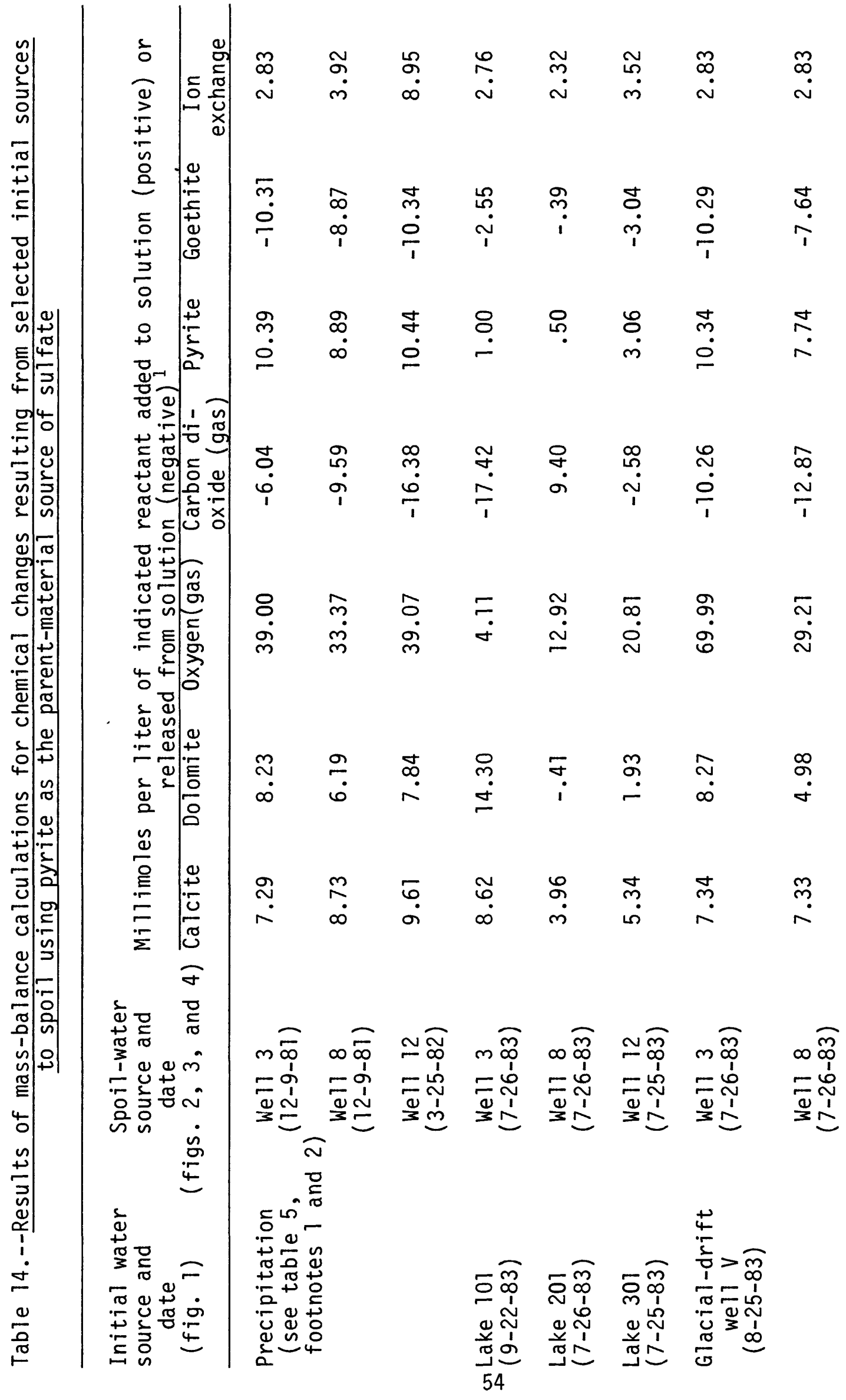




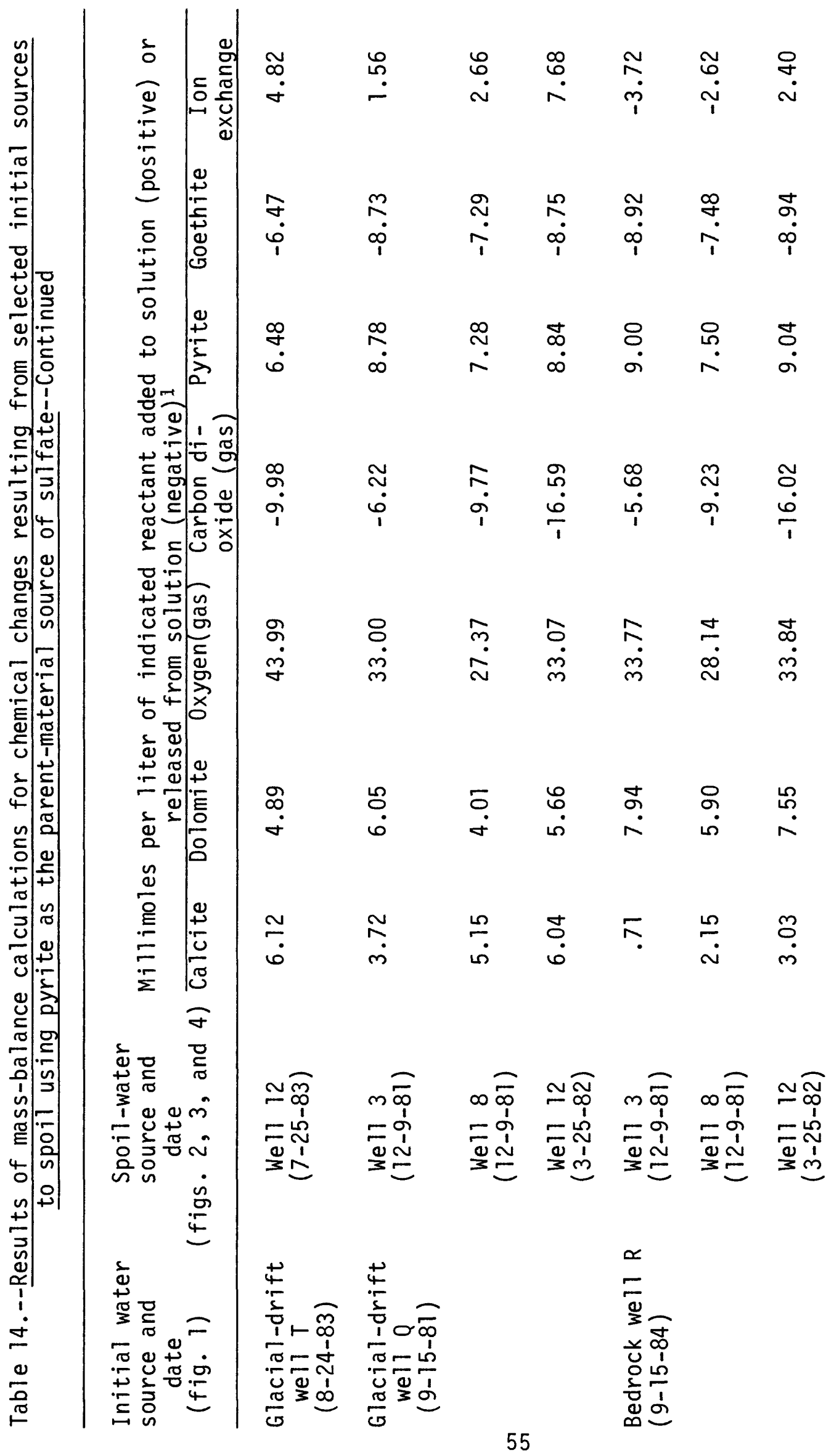




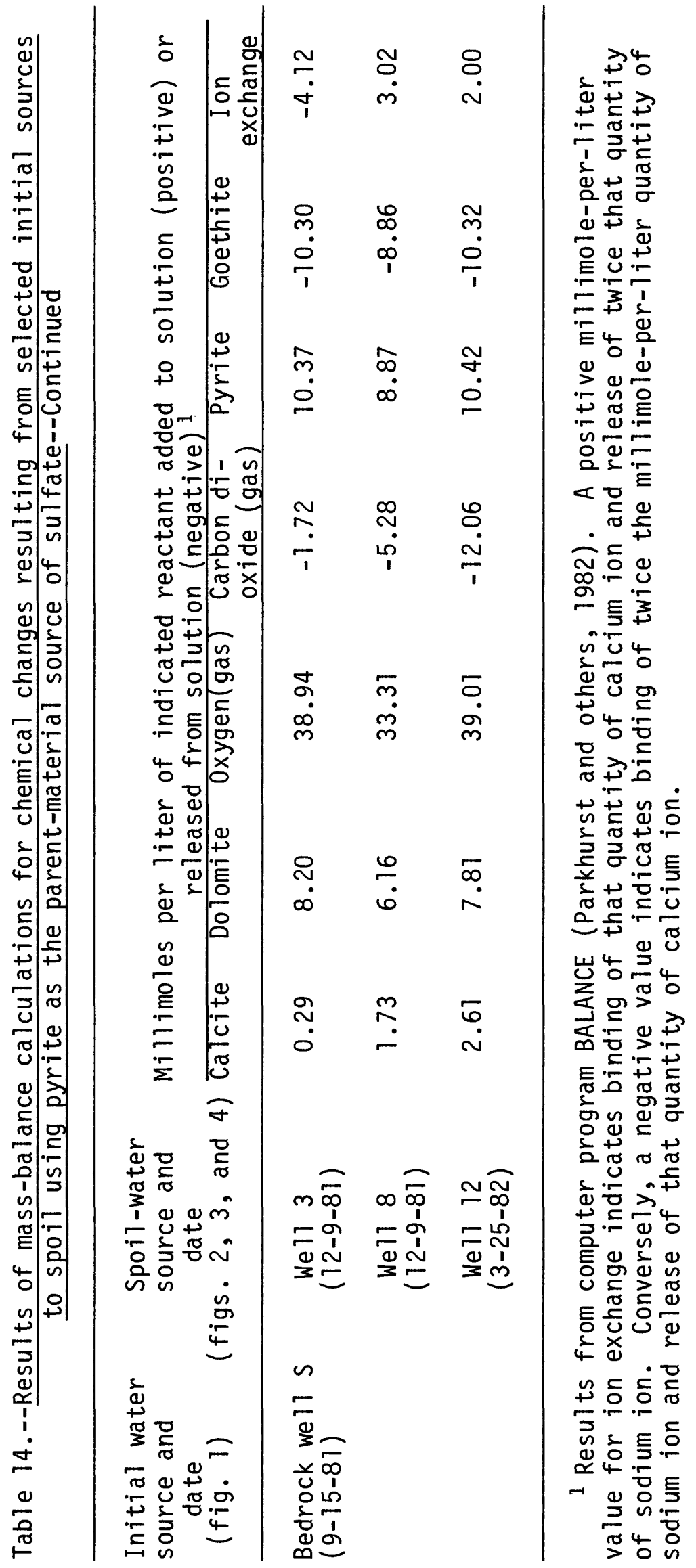




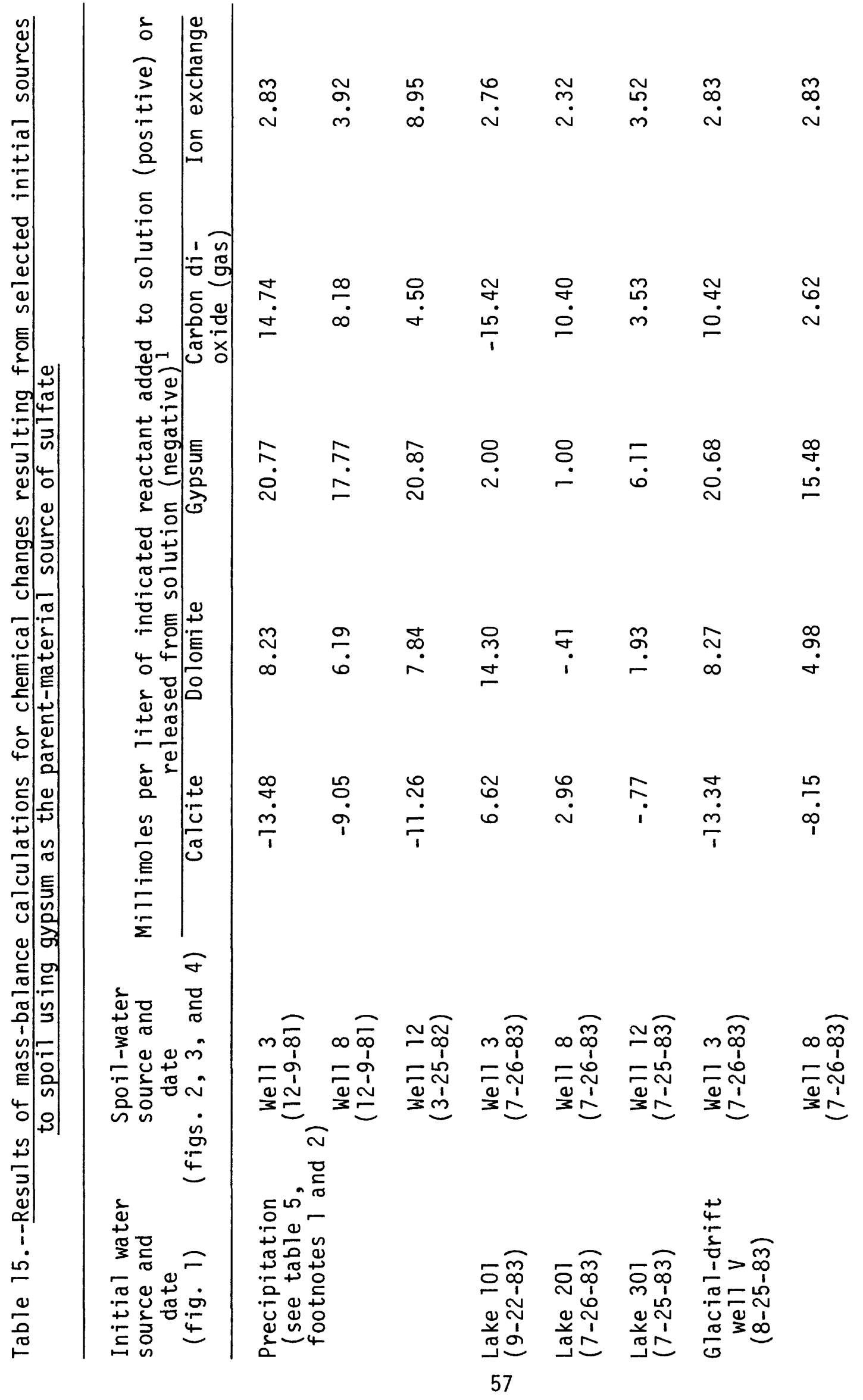




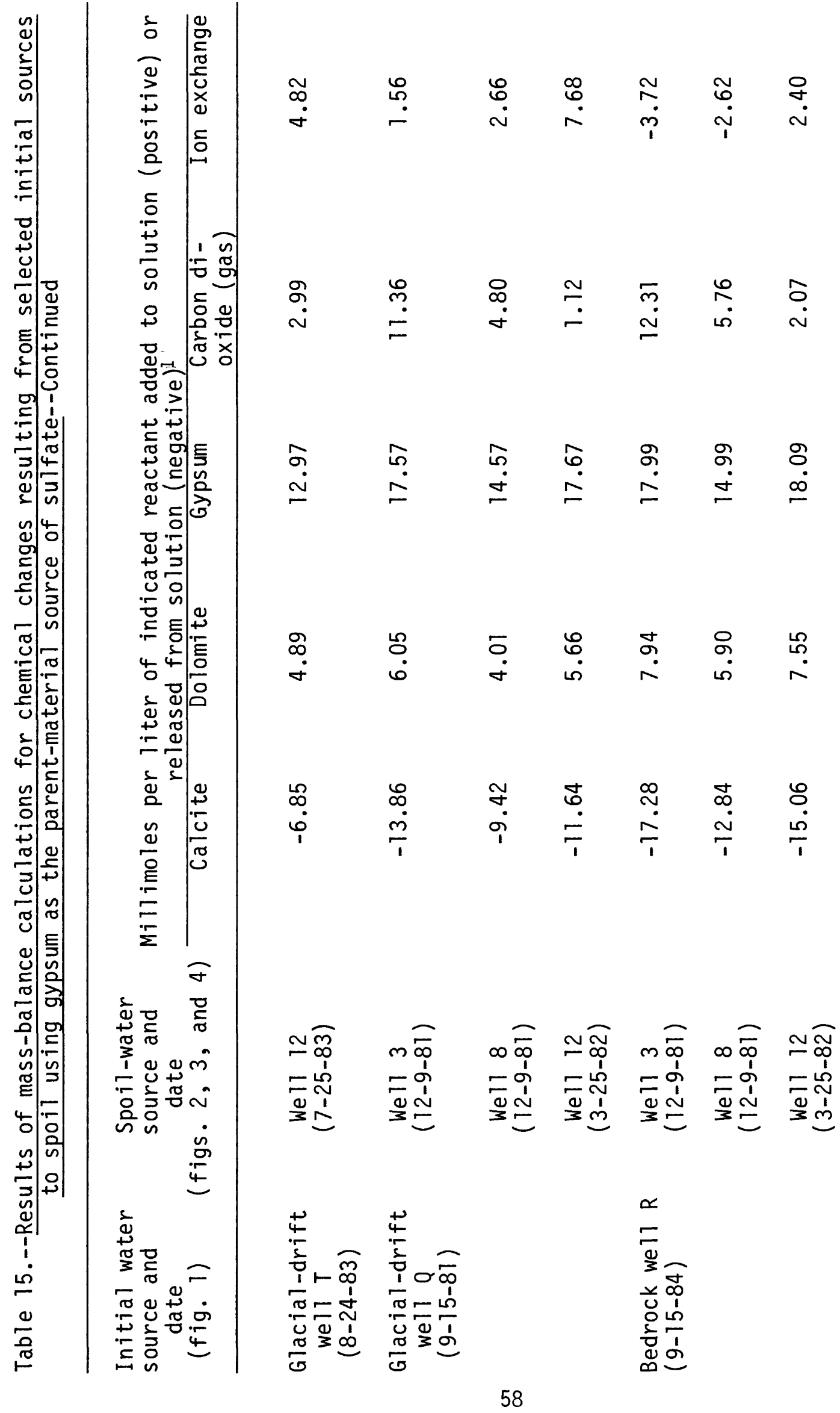




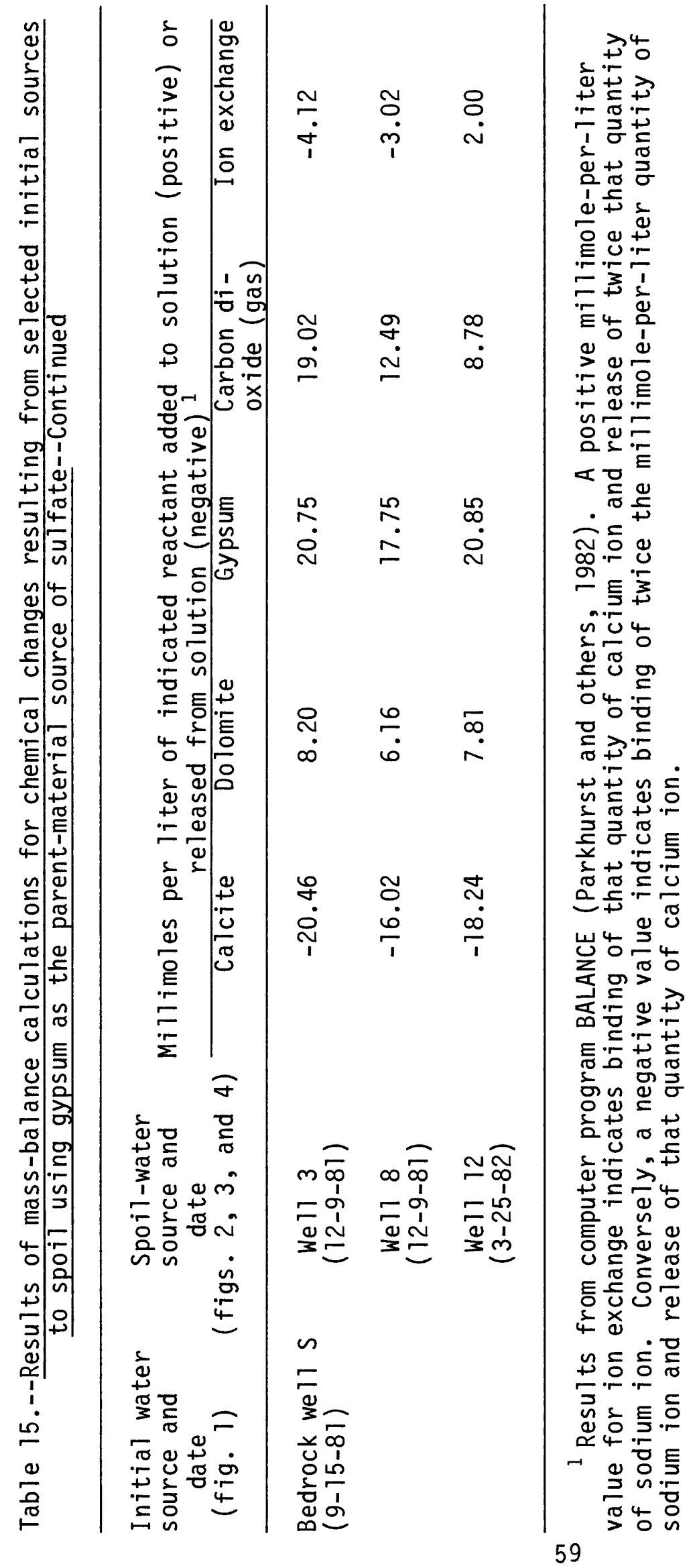


The chemical processes that occur as water moves into spoil probably are a combination of the two sets of processes shown in tables 14 and 15. Generally, these processes are dissolution and precipitation of calcite, dissolution of dolomite, dissolution of pyrite and gypsum, precipitation of goethite (or iron hydroxide), and release of sodium ions by ion exchange.

\section{SUMMARY}

The near-surface geology of northern Missouri consists of quaternary loess, alluvium, and glacial drift overlying Pennsylvanian bedrock. The loess is composed of fine-grained, wind-blown material and occurs on the higher ridges. The alluvium and glacial drift are composed of sand, silt, and clay. The bedrock is composed of shale, limestone, sandstone, and coal. Coal deposits of interest are the Mulky and Bevier-Wheeler seams that generally are within 100 feet of land surface. Spoil, which consists of a heterogeneous mixture of glacial drift and broken bedrock, is present where the coal seams have been strip mined. Most older mines were abandoned without reclamation.

Alluvium, glacial drift, bedrock, and spoil are aquifers in the study area. Transmissivities generally are greatest for spoil and decrease in the following order: alluvium, glacial drift, and bedrock.

Recharge to alluvium is by infiltration of precipitation and by lateral and probably vertical flow from adjacent aquifers. Recharge to glacial drift is by infiltration of precipitation and lateral flow from adjacent aquifers. Recharge to bedrock is by infiltration of precipitation and vertical flow from glacial drift. Recharge to spoil is from precipitation, lateral flow from glacial drift, and lateral and vertical flow from bedrock. Precipitation probably is the major source of recharge, both directly by infiltration and indirectly as leakage from high-wall lakes. The rate of recharge to the aquifers is unknown, but probably is small. Ground-water discharge from glacial drift, bedrock, and spoil is to alluvium, which generally discharges to streams.

The potentiometric surface in the shallow aquifers generally conformed to the topography. The direction of flow generally was from high-wall lakes in the spoil toward the East Fork Little Chariton River or South Fork Claybank Creek.

Water from high-wall lakes had a median dissolved-solids concentration of 2,059 milligrams per liter and was a calcium magnesium sulfate type. Water from glacial drift had a median dissolved-solids concentration of 559 milligrams per liter and was either a calcium magnesium bicarbonate or calcium magnesium sulfate type. Water from bedrock had a median dissolved-solids concentration of 775.5 milligrams per liter and was either a sodium bicarbonate or calcium bicarbonate type. Water from spoil had a median dissolved-solids concentration of 2,860 milligrams per liter and was a calcium magnesium sulfate type. Water from spoil had a median $\mathrm{pH}$ value of 6.6 , which was less than the median $\mathrm{pH}$ value of water from drift (7.4) and the median $\mathrm{pH}$ value of water from bedrock (9.0).

Dissolved-solids concentration increased downgradient in two of three spoil areas. Although differences in water quality existed between the three spoil areas, the differences cannot be attributed to the age of the spoil. The changes occurred in fewer than 12 years and have persisted for more than 40 years. 
Water from high-wall lakes, glacial drift, bedrock, and spoil was saturated with respect to calcite, dolomite, and quartz, but only water from spoil was saturated with respect to gypsum. The difference can be attributed either to dissolution of freshly exposed gypsum or to oxidation of freshly exposed pyrite, or both, in spoil. The exposure of the minerals probably results from disturbance of the glacial drift and bedrock overburden during mining.

The general chemical processes that occur as water moves into spoil are dissolution and precipitation of calcite, dissolution of dolomite, consumption of oxygen gas, consumption and release of carbon dioxide gas, dissolution of pyrite and gypsum, precipitation of goethite (or iron hydroxide), and release of sodium ions by ion exchange. 


\section{REFERENCES}

Anderson, K. H., coordinator, 1979, Geologic map of Missouri: Rolla, Missouri Division of Geology and Land Survey, scale 1:500,000.

Draney, D. E., 1982, Physical properties of coal mine spoil piles of various ages in Macon County, Missouri: Columbia, University of Missouri, unpublished M.S. thesis, 109 p.

Fenneman, N. M., 1938, Physiography of eastern United States: New York, McGraw Hill, 714 p.

Freeze, R. A., and Cherry, J. A., 1979, Groundwater: Englewood Cliffs, N. J., Prentice-Hall, 604 p.

Gann, E. E., Harvey, E. J., Jeffery, H. G., and Fuller, D. L., 1971, Water resources of northeastern Missouri: U.S. Geological Survey Hydrologic Investigations Atlas $\mathrm{HA}-372,4$ sheets.

Gentile, R. J., 1967, Mineral commodities of Macon and Randolph Counties: Rolla, Missouri Division of Geology and Land Survey Report of Investigations $40,106 \mathrm{p}$.

Haliburton Associates, 1981, Prairie Hills controlled industrial waste treatment and disposal facility: Wichita, Kans., Missouri Industrial Environmental Services, Inc., 1981, 402 p., 11 appendices (permit application to Missouri Department of Natural Resources).

Horner and Shifrin, Inc., 1981, Groundwater study for the general area of the Prairie Hill Mine (near Moberly Missouri): St. Louis, prepared for Associated Electric Cooperative, Inc., 45 p., 19 exhibits, 6 appendices.

Lewis, J. C., 1982, Surficial hydrogeology of a small drainage basin near Excello, Macon County, Missouri: Columbia, University of Missouri, unpublished M.S. thesis, $81 \mathrm{p}$.

National Weather Service, 1981-83, Climatological data, Missouri: Asheville, N.C., U.S. Department of Commerce, v. 85, nos. 5-13; v. 86, nos. 1-13; v. 87 , nos. 1-13.

Older, Kathleen, 1982, A mineralogic study of coal mine spoil in north central Missouri: Columbia, University of Missouri, unpublished M.S. thesis, $86 \mathrm{p}$.

Parkhurst, D. L., Plummer, L. N., and Thorstenson, D. C., 1982, BALANCE -- A computer program for calculating mass transfer for geochemical reations in ground water: U.S. Geological Survey Water-Resources Investigations $82-060,29 \mathrm{p}$.

Plumer, L. N., Jones, B. F., and Truesdell, A. H., 1976 (revised 1978), WATEQF--A FORTRAN IV version of WATEQF, a computer program for calculating chemical equilibrium of natural waters: U.S. Geological Survey Water-Resources Investigations $76-13,63 \mathrm{p}$. 
Robertson, C. E., 1971, Evaluation of Missouri's coal resources: Rolla, Missouri Division of Geology and Land Survey Report of Investigations 48, $100 \mathrm{p}$.

1973, Mineable coal reserves of Missouri: Rolla, Missouri Division of Geology and Land Survey Report of Investigations 55, 71 p.

Robertson, C. E., and Smith, D. C., 1981, Coal resources and reserves of Missouri: Rolla, Missouri Division of Geology and Land Survey Report of Investigations $66,49 \mathrm{p}$.

Searight, W. V., 1967, Mineral fuel resources, coal, in Mineral and water resources of Missouri: Washington, D.C., U.S. Government Printing Office, U.S. 90th Congress, 1st session, Senate Document 19, p. 235-243 and 251-252.

Seifert, G. G., 1982, Hydrogeochemistry of coal mine spoil piles of various ages in Macon County, Missouri: Columbia, University of Missouri, unpublished M.S thesis, $101 \mathrm{p}$.

Shell Engineering Associates, 1981 Engineering study and report for solid waste disposal permit--Thomas Hill operation: Columbia, Mo., prepared for Associated Electric Cooperative, Inc., 62 p., 6 appendices.

Skelton, John, 1971, Carryover storage requirements for reservoir design in Missouri: Rolla, Missouri Division of Geology and Land Survey Water Resources Report 25, 43 p.

U.S. Department of the Interior, Office of Surface Mining Reclamation and Enforcement, 1979, Surface coal mining and reclamation operation: Federal Register, v. 44, no. 50, Tuesday, March 13, 1979, part II, p. 15311-15463.

Vaill, J. E., and Barks, J. H., 1980, Physical environment and hydrologic characteristics of coal-mining areas in Missouri: U.S. Geological Survey Water-Resources Investigations 80-67, $33 \mathrm{p}$.

Wedge, W. K., Bhatia, D. M. S., and Rueff, A. W., 1976, Chemical analyses of selected Missouri coals and some statistical implications: Rolla, Missouri Division of Geology and Land Survey Report of Investigations 60, 36 p. 
SUPPLEMENTAL DATA 


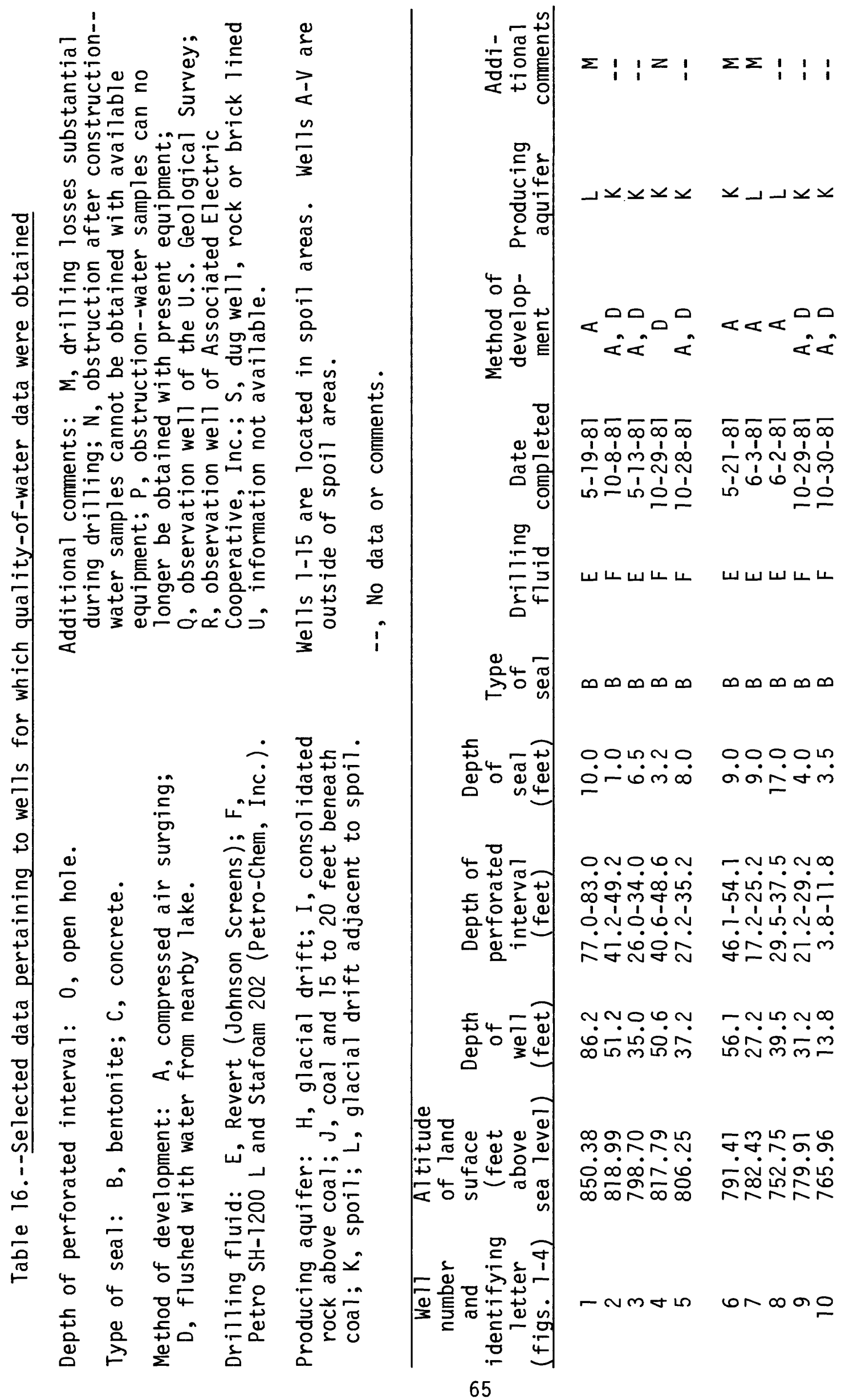




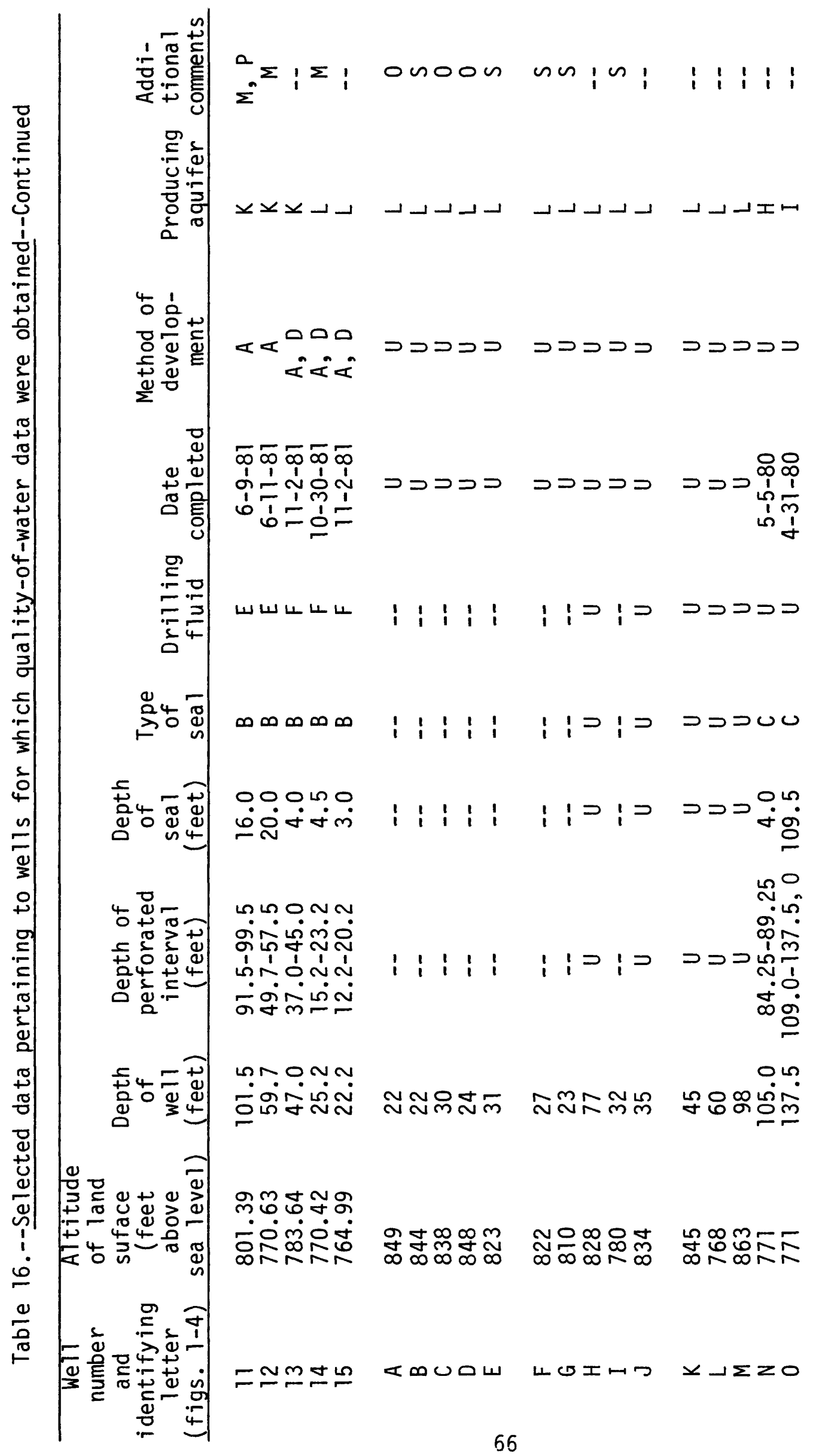




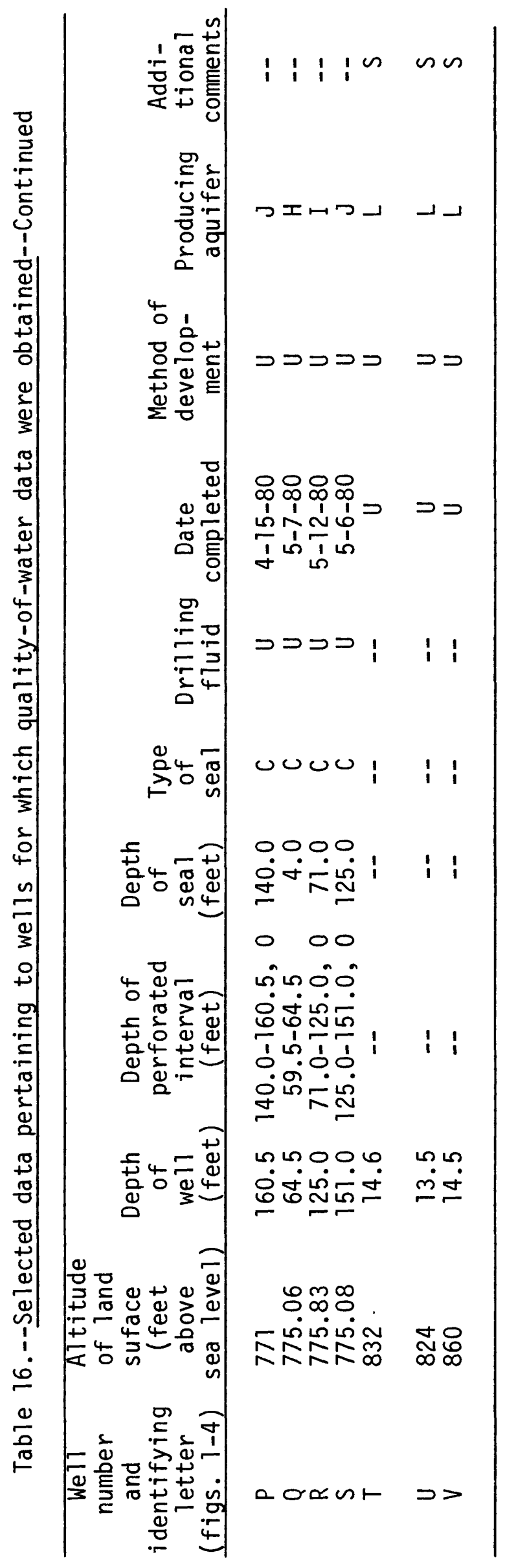




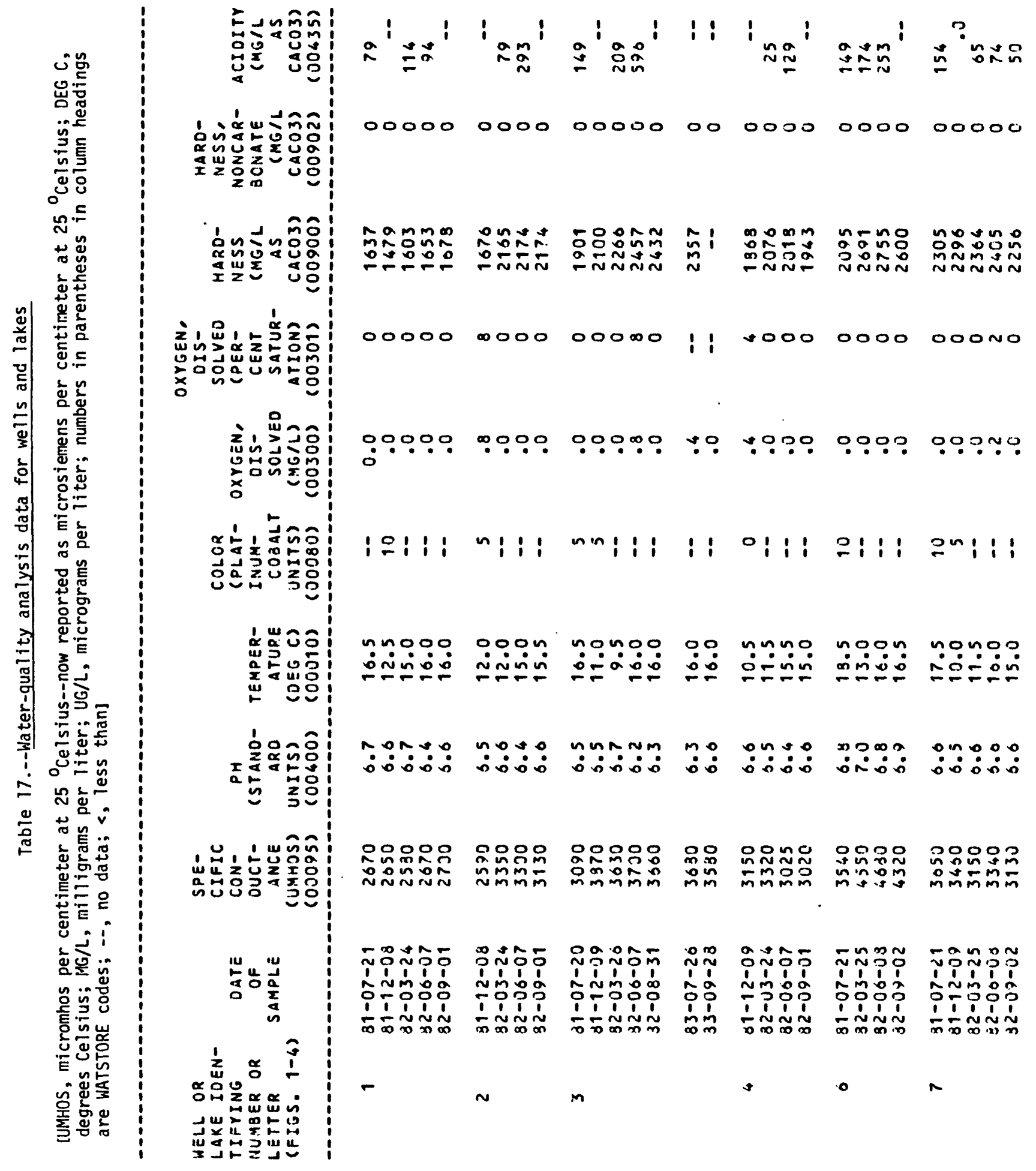




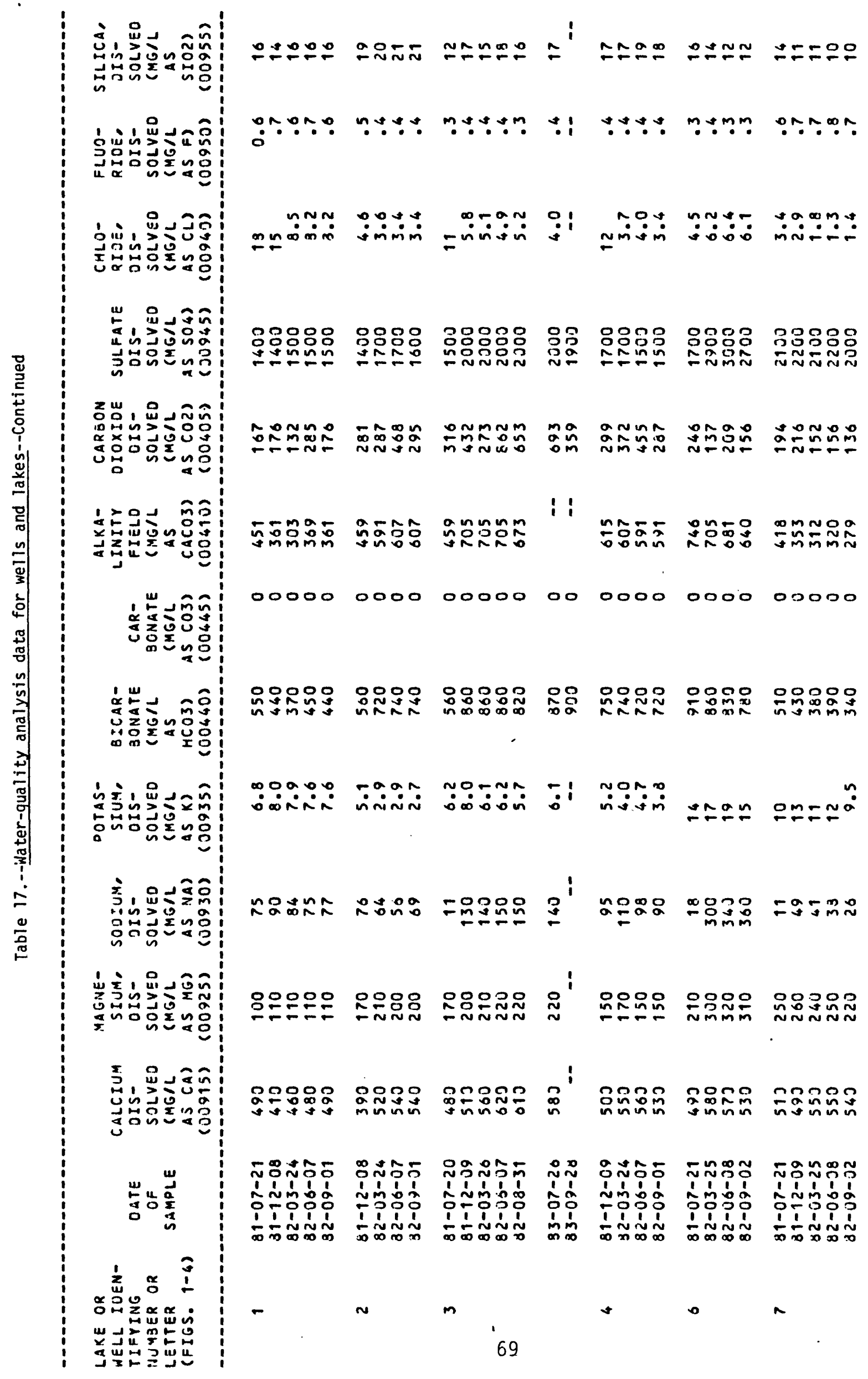




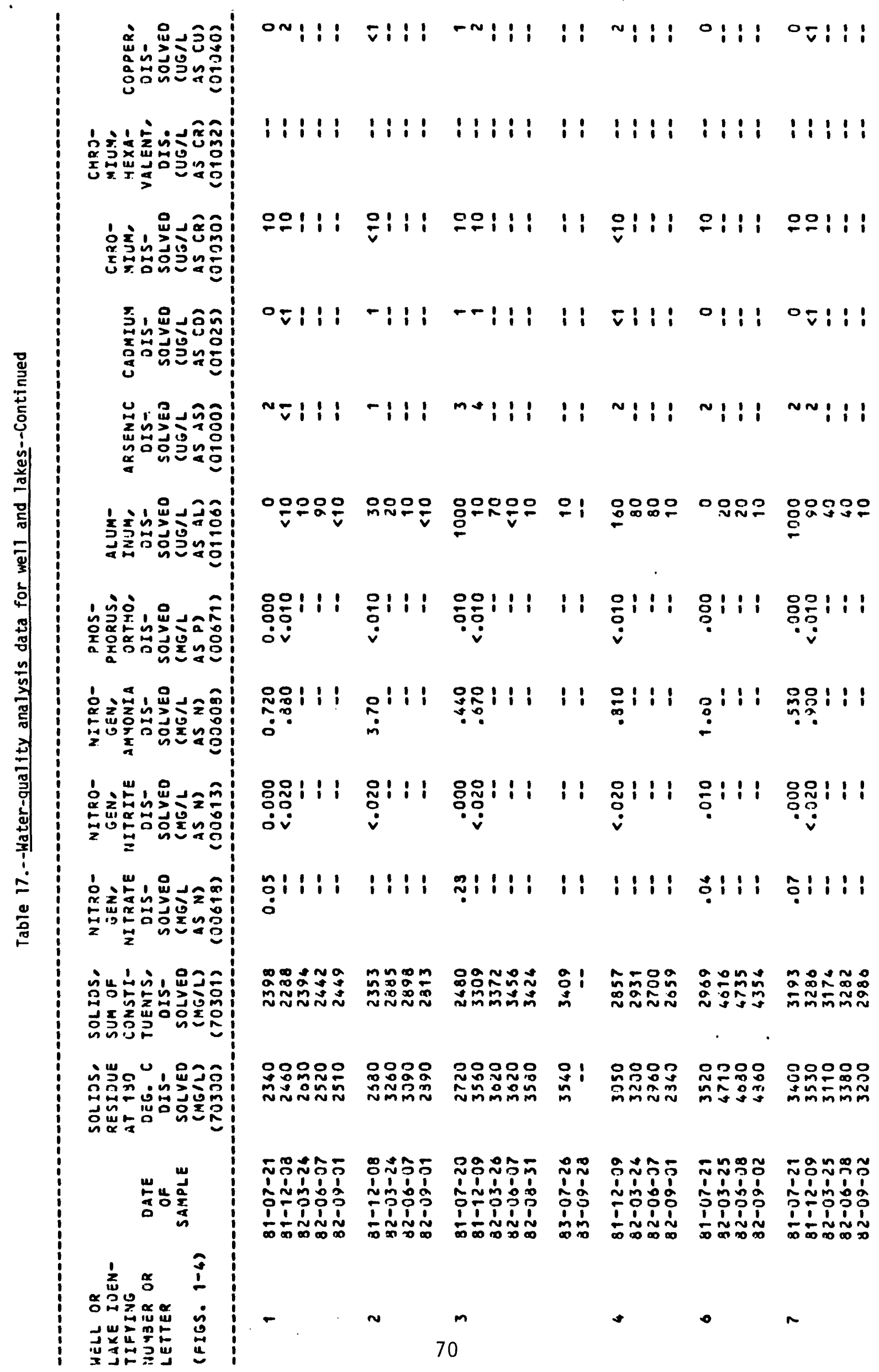


ن的品총여

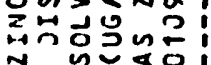

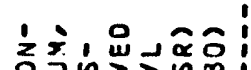

的的品

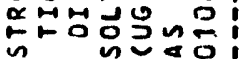

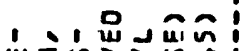

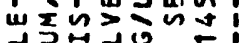

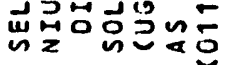

竞, 品会合! 넝엉 넝여웡

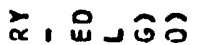

讨的出乐品 u율ㅁㄴ?

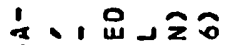

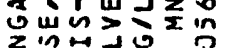

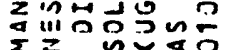
$x=$ n๐a

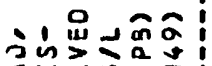

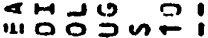

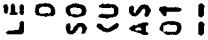

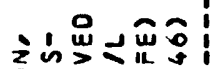
zूn 때의

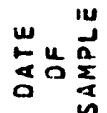

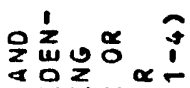

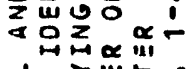
Jw แхM x

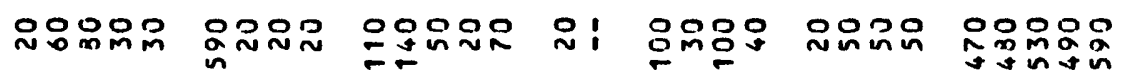

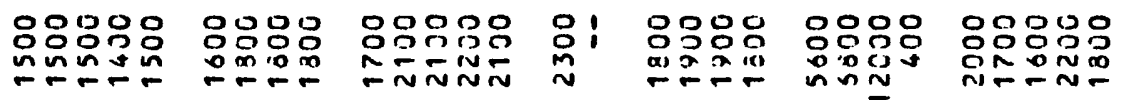
ō!!

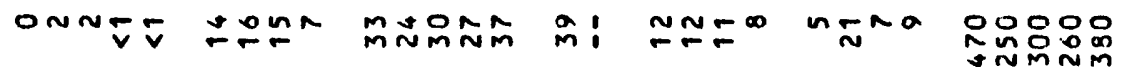
落! I

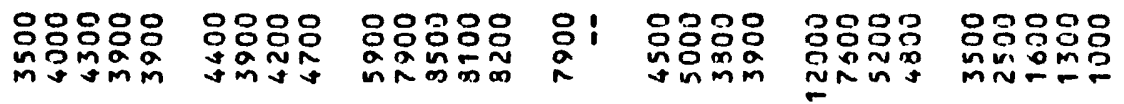
oह!!

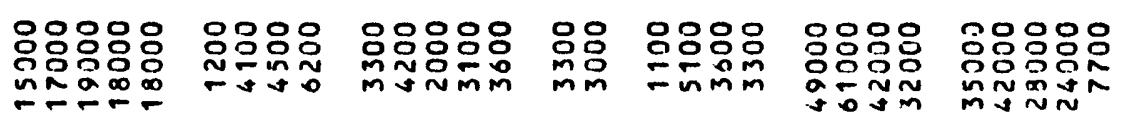

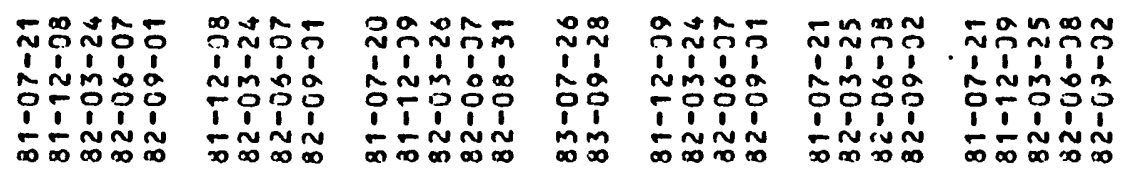




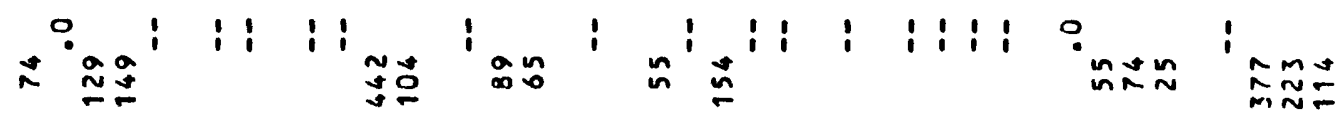

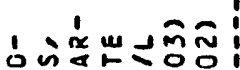
000000000000000000000000000000000

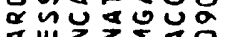
$x \geq 0$

dus 角号! a出乎边

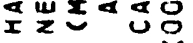

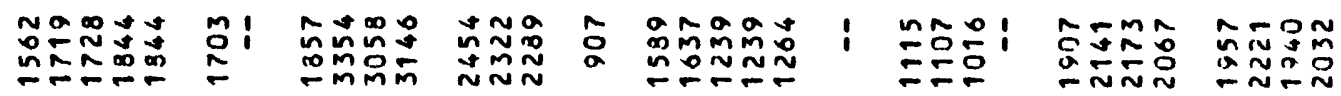

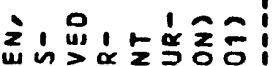

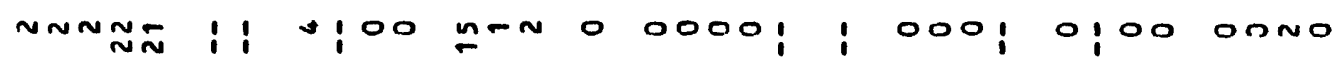

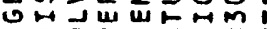

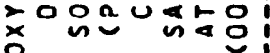

خ.

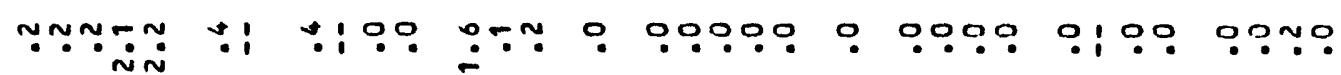

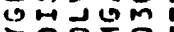

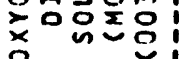

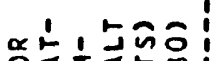

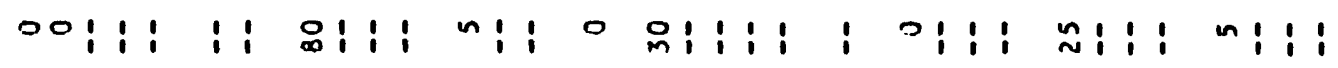

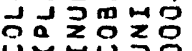
«แง

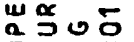
im nooon un ounn $\therefore \dot{0} \dot{0}:$

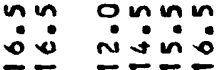
000

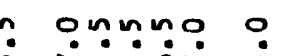
onon ogno non? 응ํํ

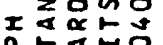

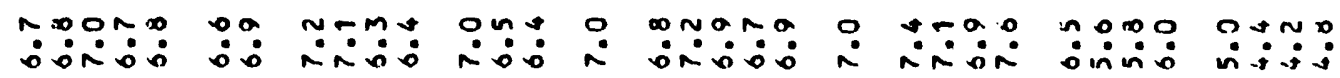
运要

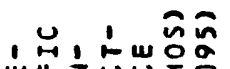

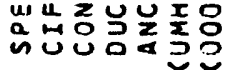

웅요

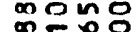
Nmํำ

\section{oo}

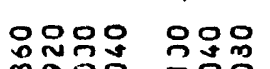
N 끔ํํ

웅응유

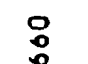

음웅요 ñn் minis 岩岩势

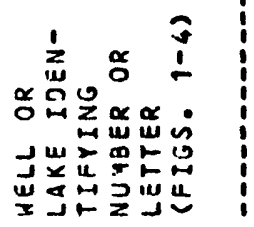

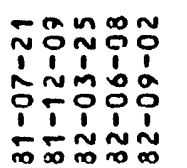

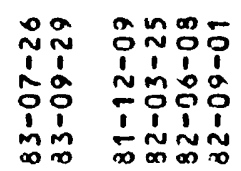
$n$
nos
1
1
0
0

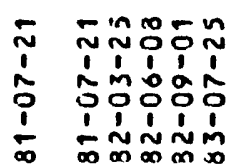

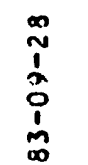

น⿻上丨

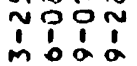
ํํㅇํㅇํㅇㅁㅇ 1是星

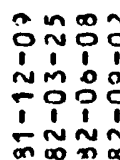

ลิกัวกี $\infty$

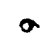

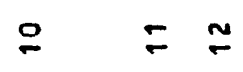

$m$

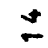

$\cong$ 


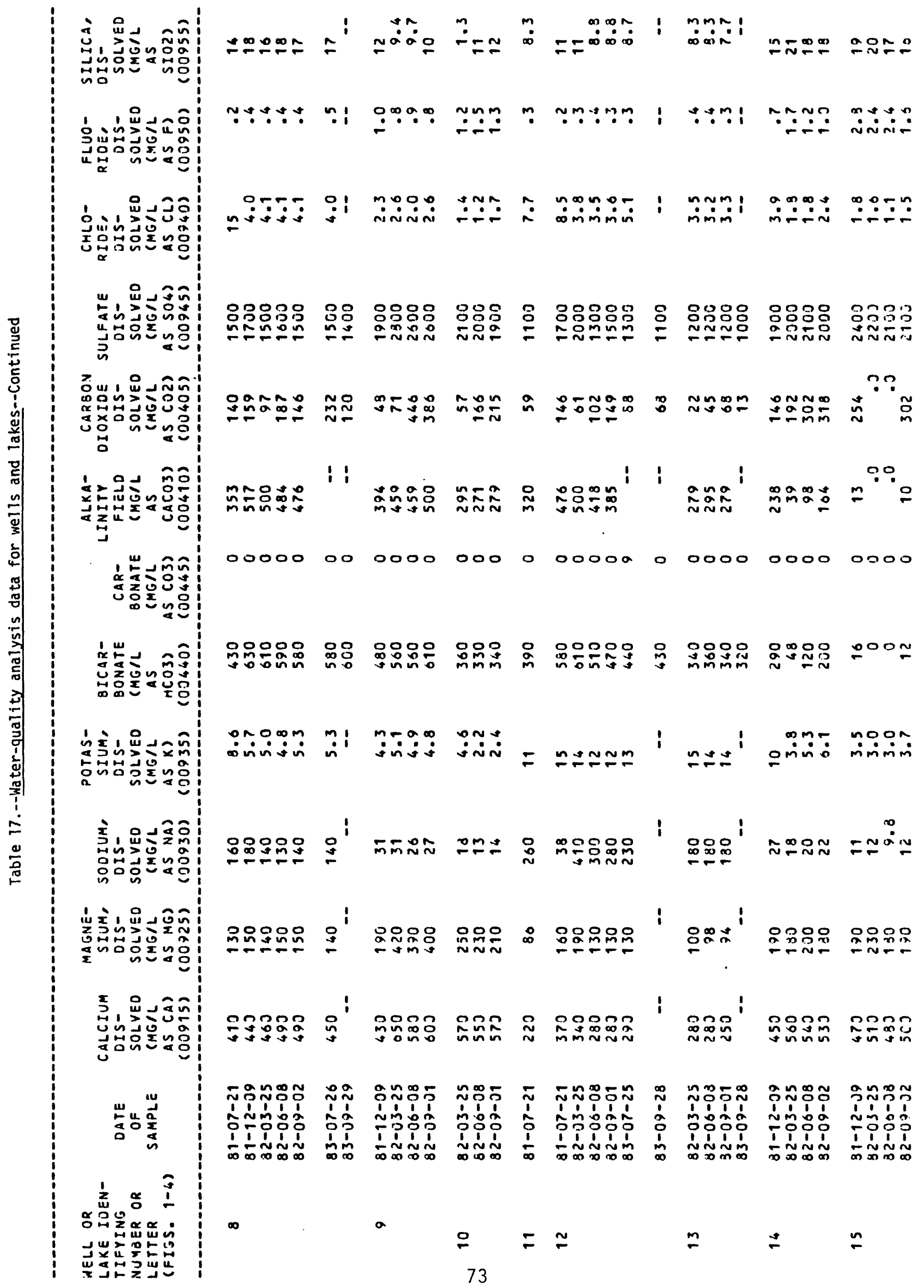




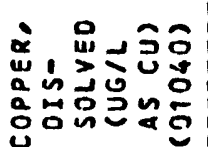

安它的余命 хว 던 딷

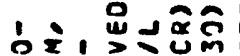

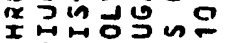

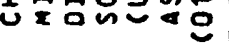

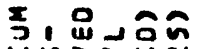

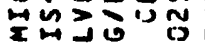
造品次方

느ำ

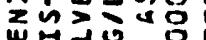
ผั口

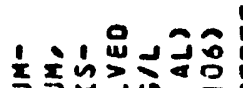

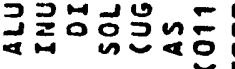

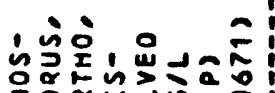

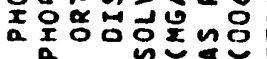

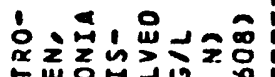

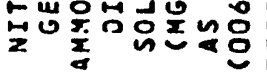

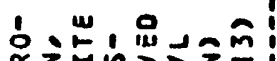

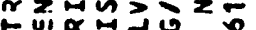

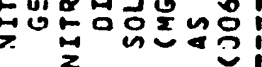

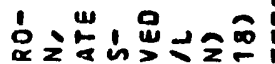

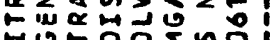

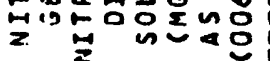

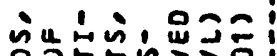
员战出出品

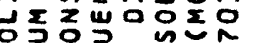
的识

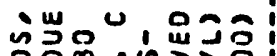

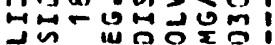

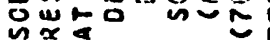

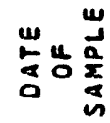

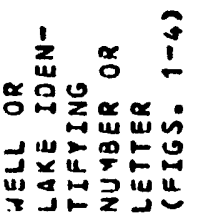

o₹i!! :

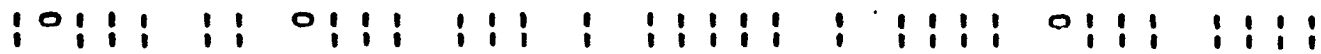

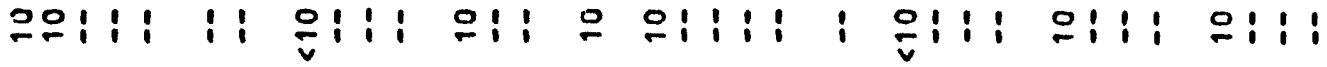

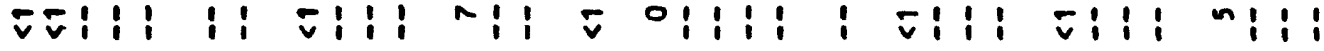

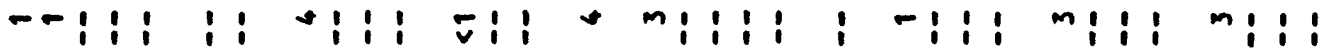

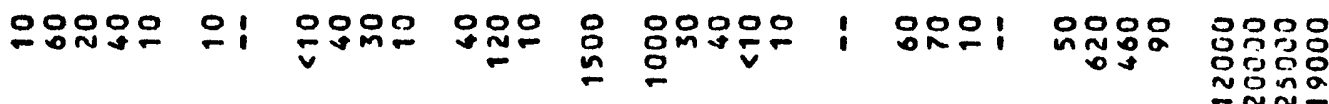

웅웅: I I I I 웅 i

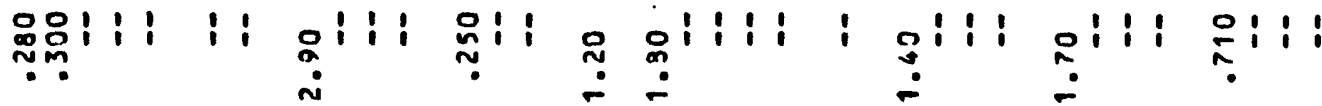

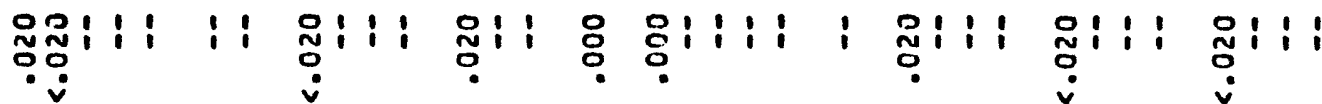

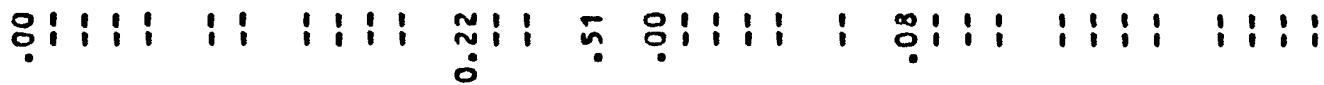

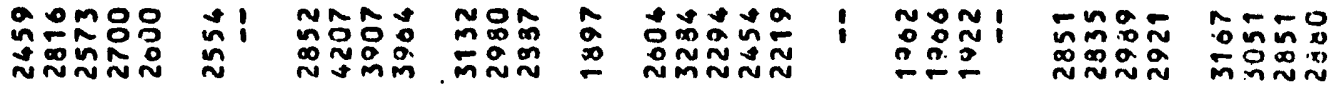

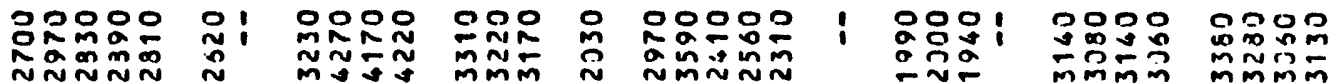

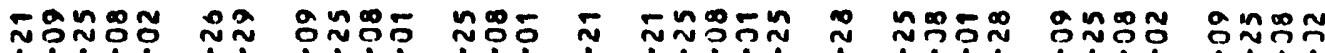

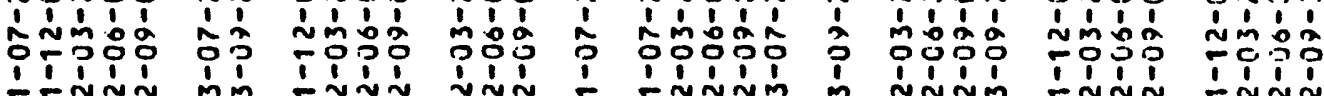

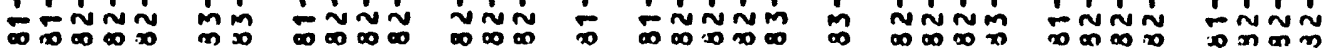

$\infty$

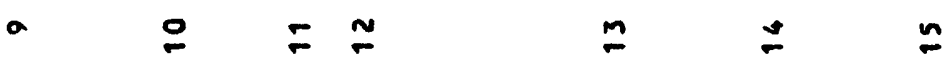




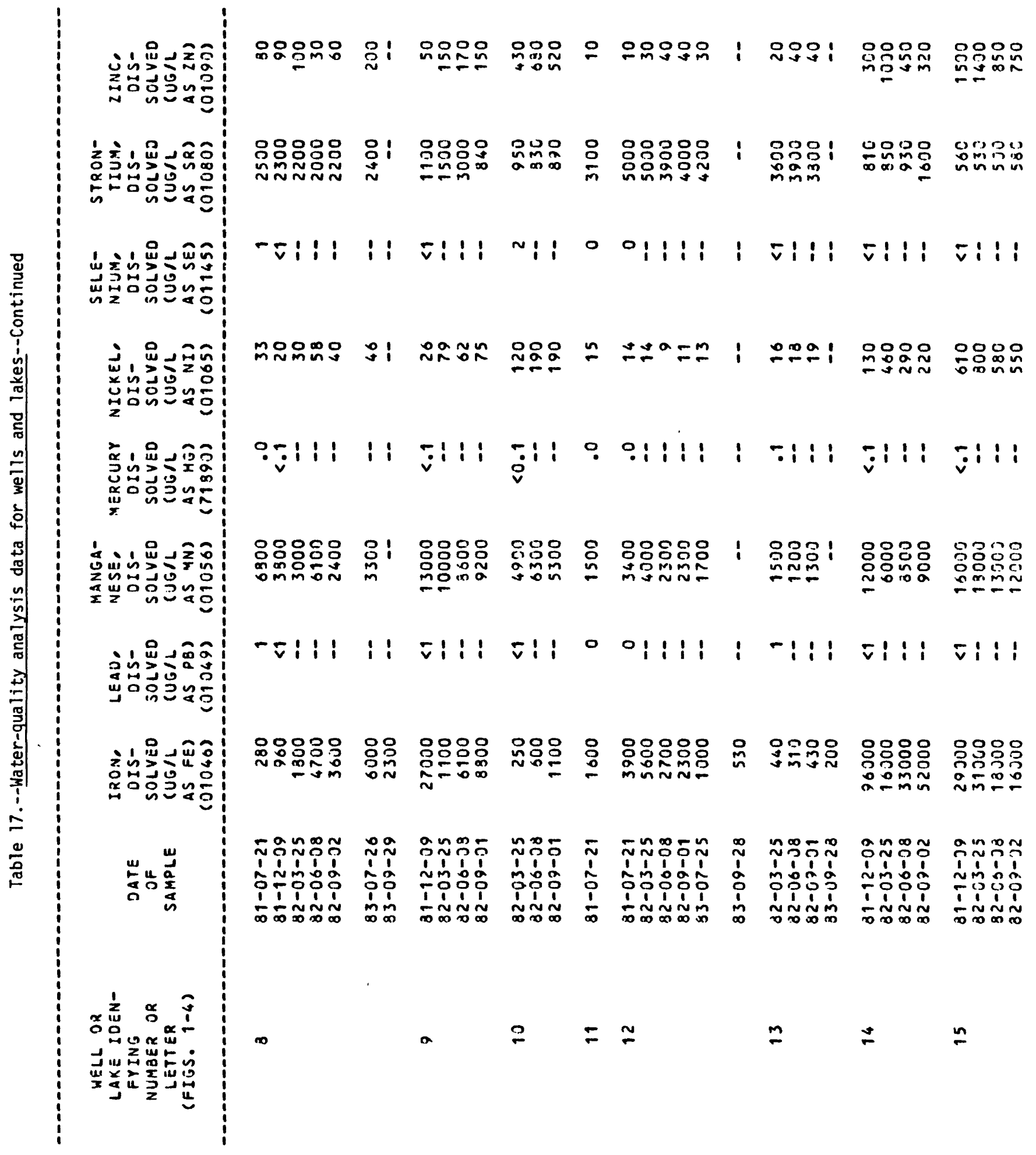




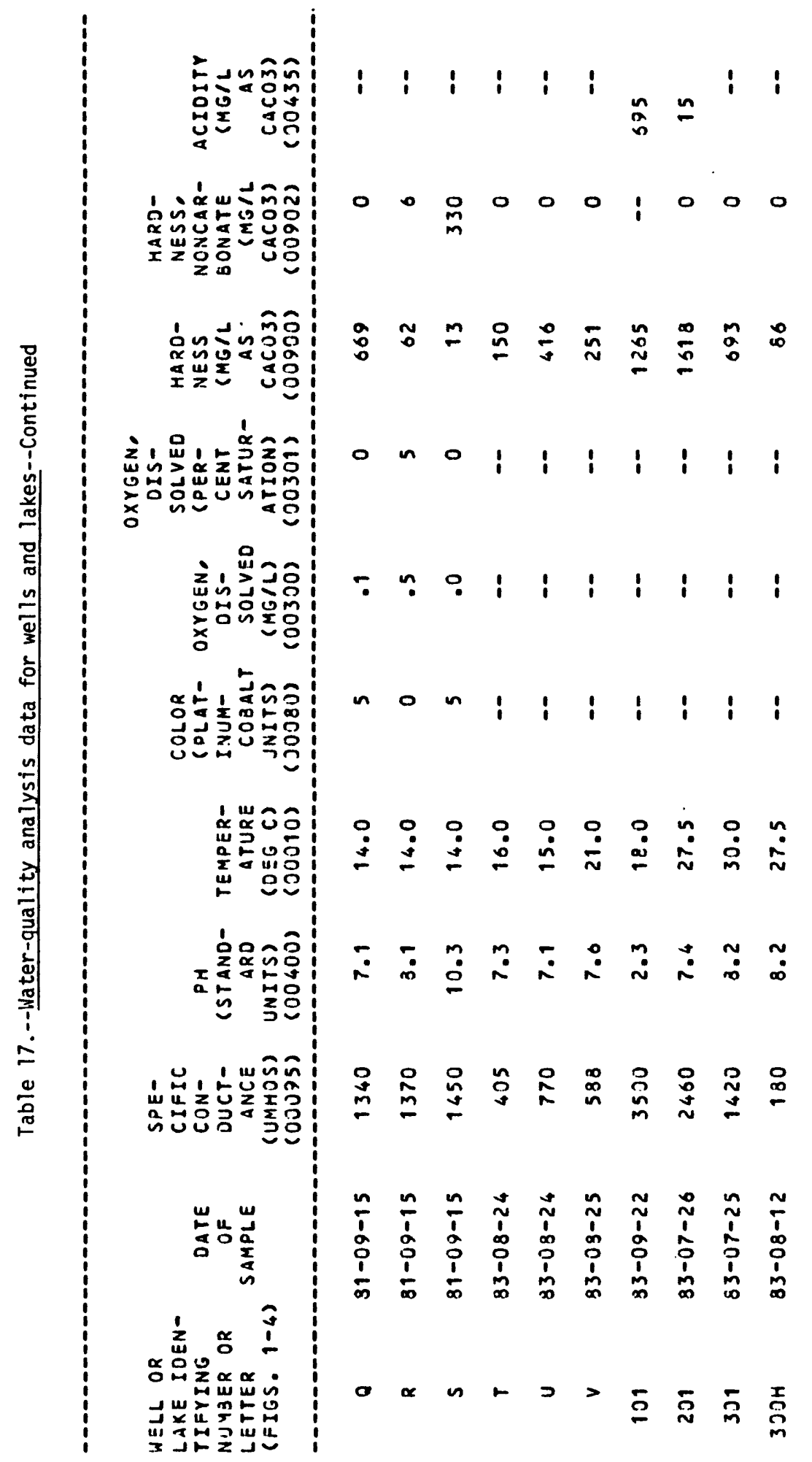




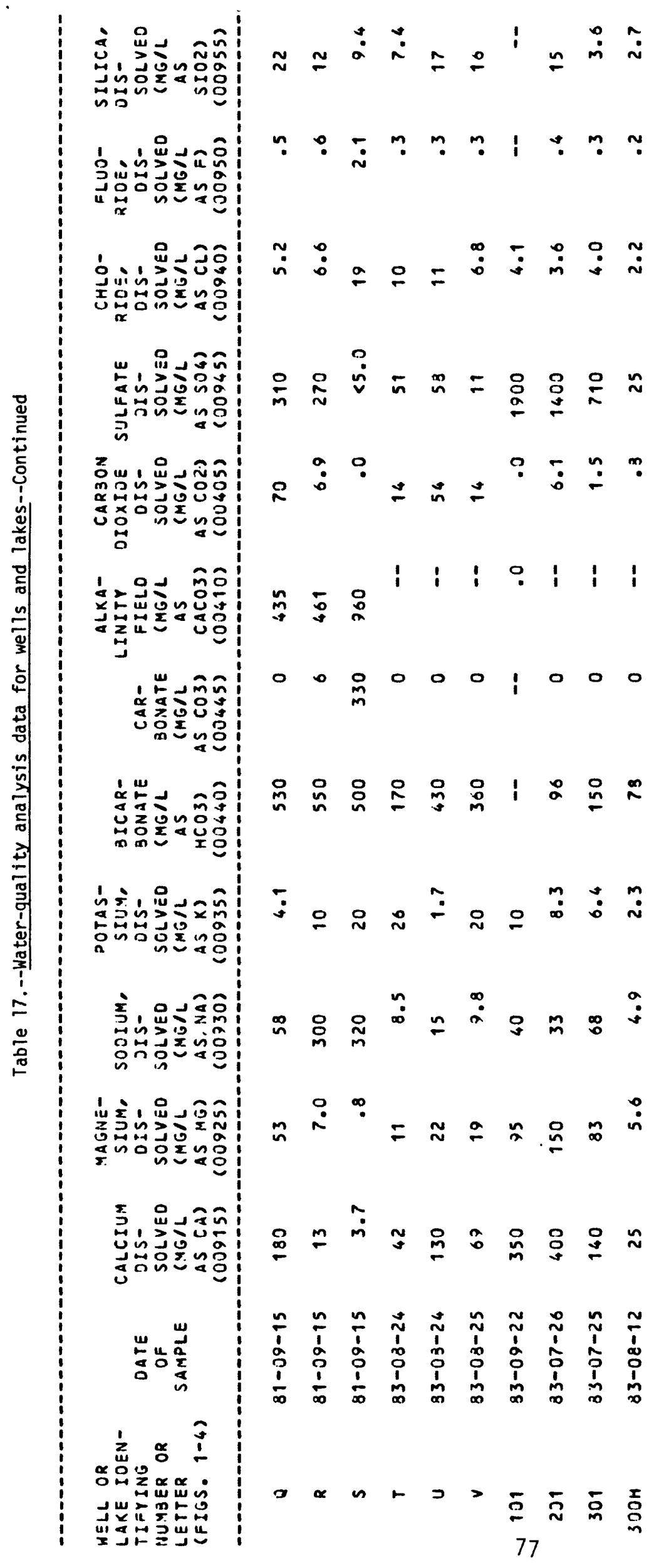




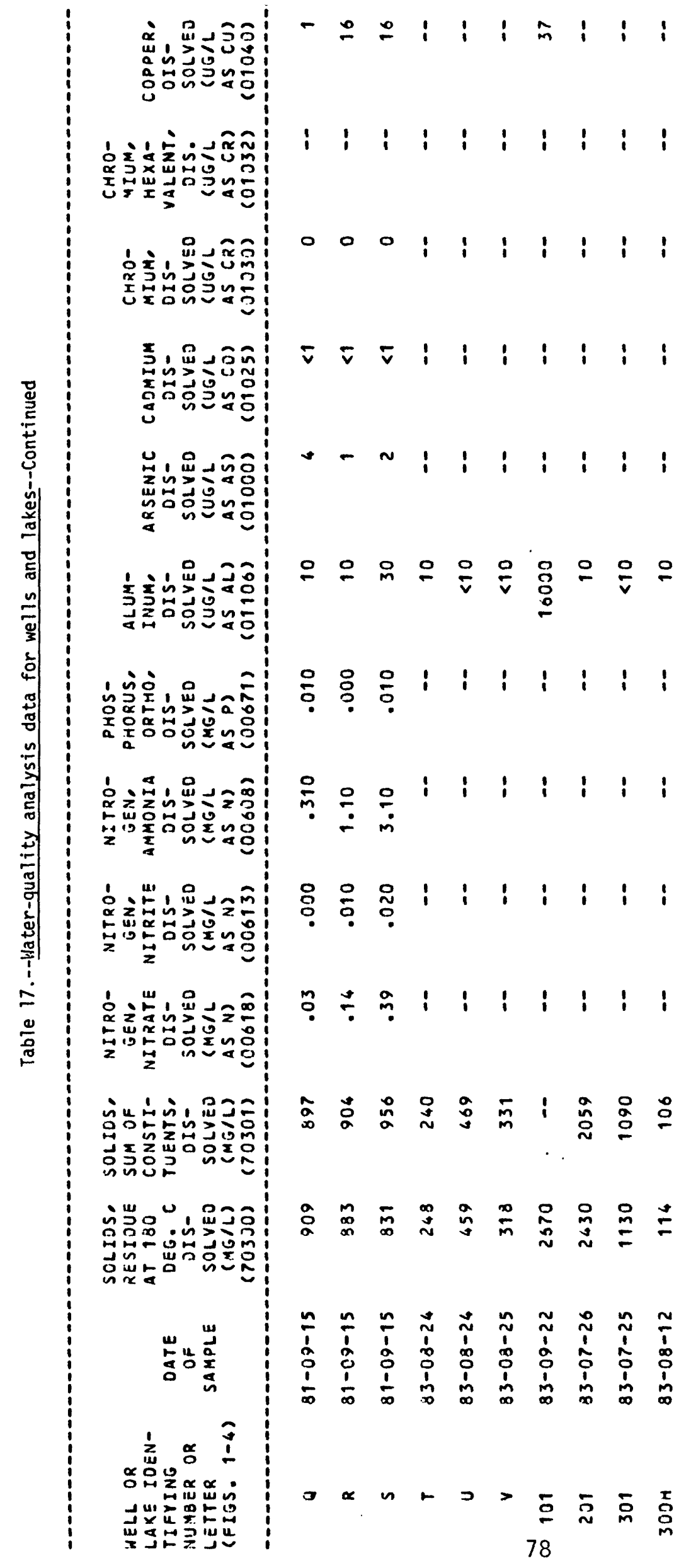




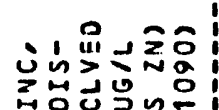

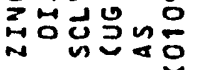

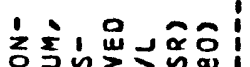

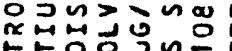

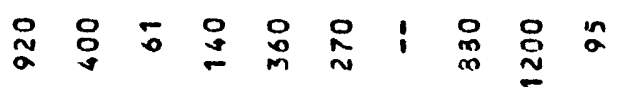

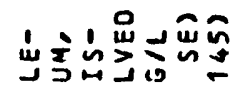

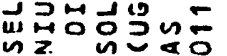

แ่

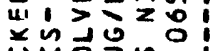
붕유뭉

สั 였

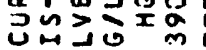
u1

…ำ

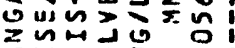

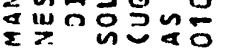

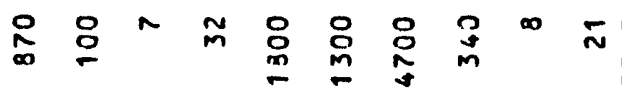

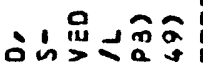

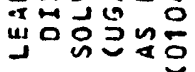

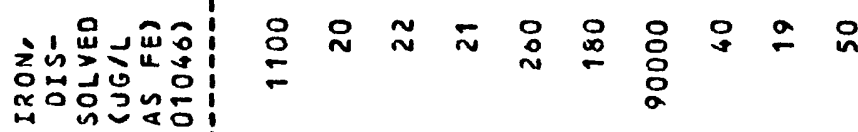

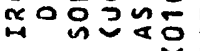

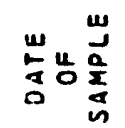

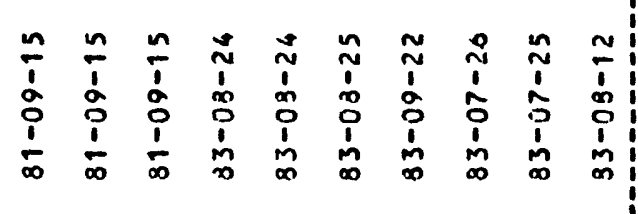

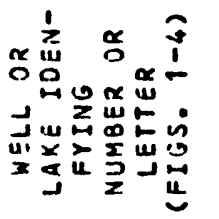

$\sim n+1 ; i=i$ i

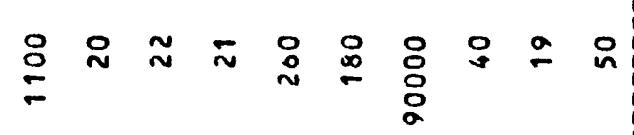

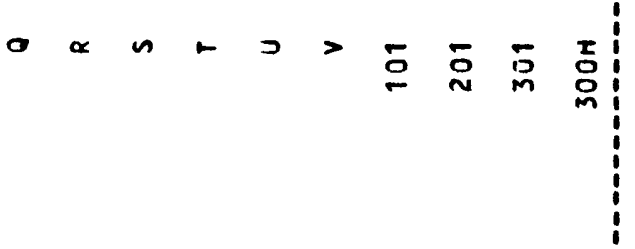




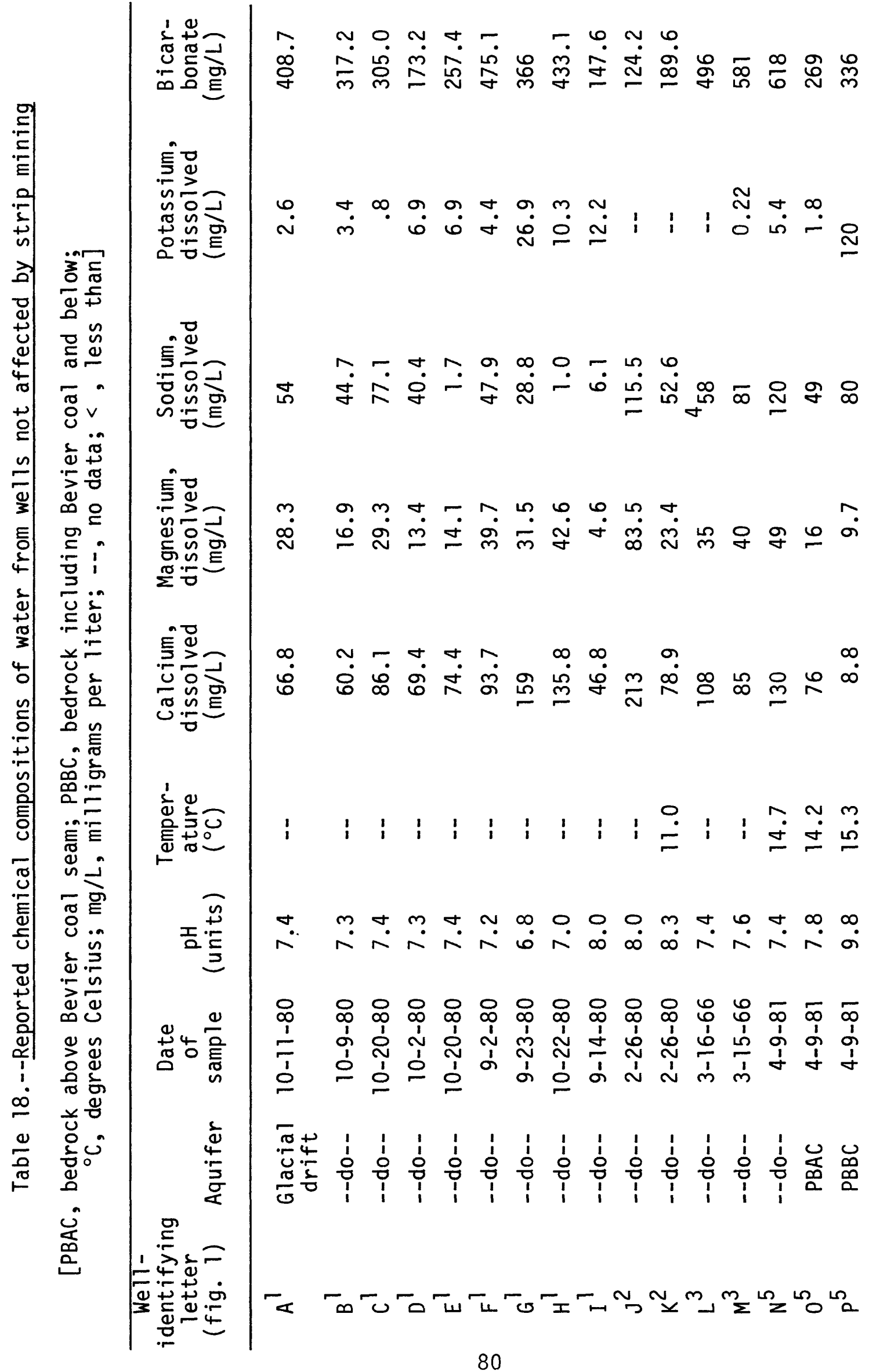




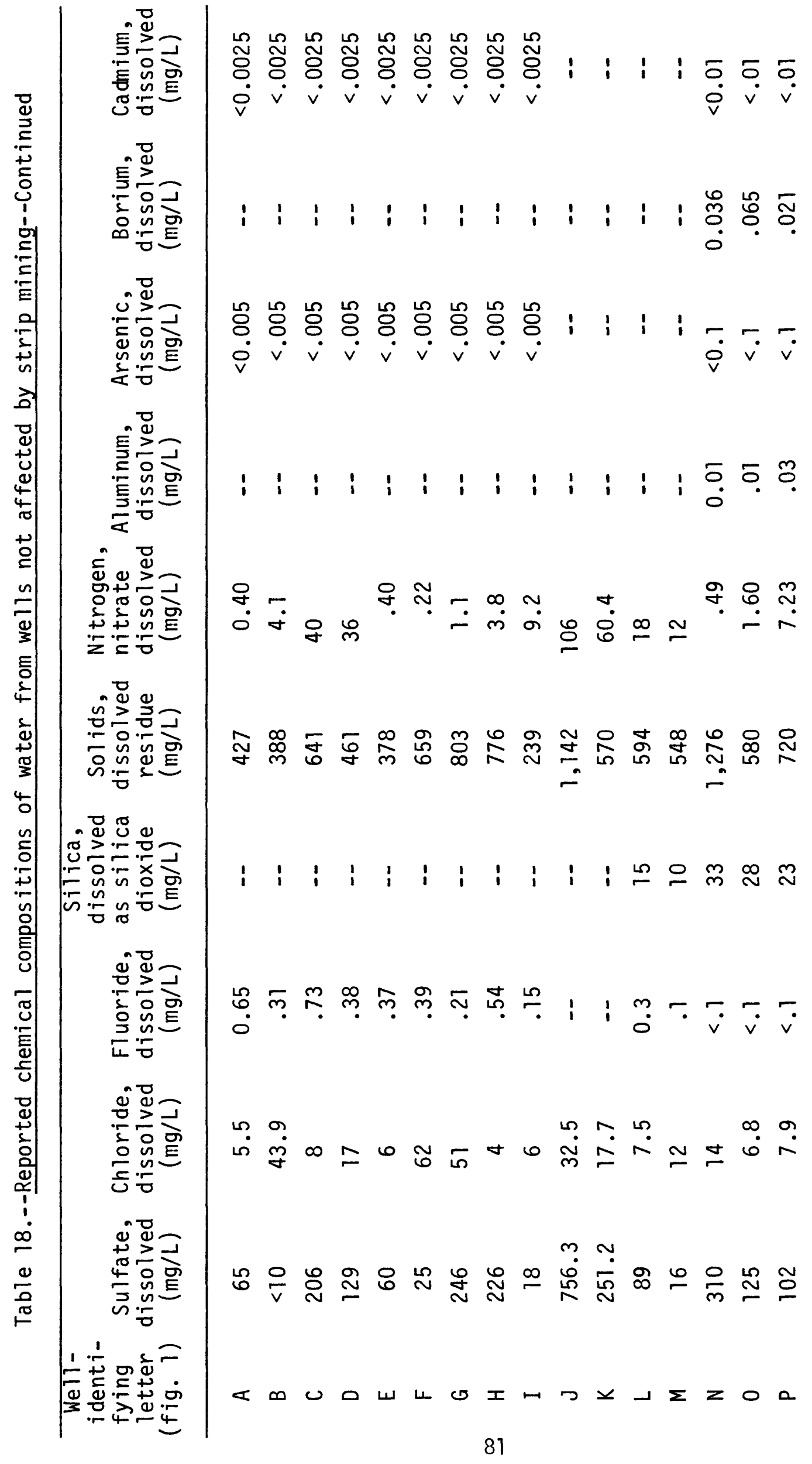




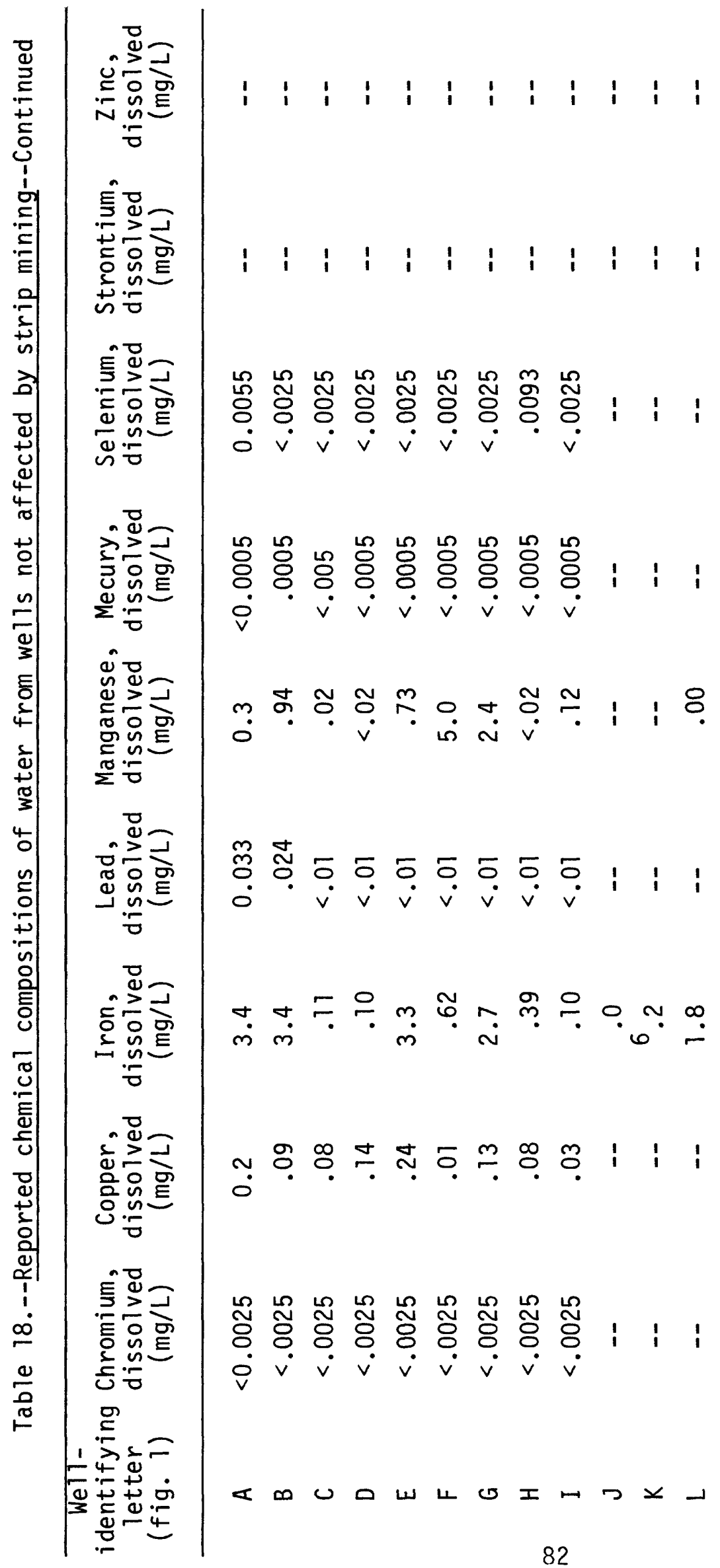




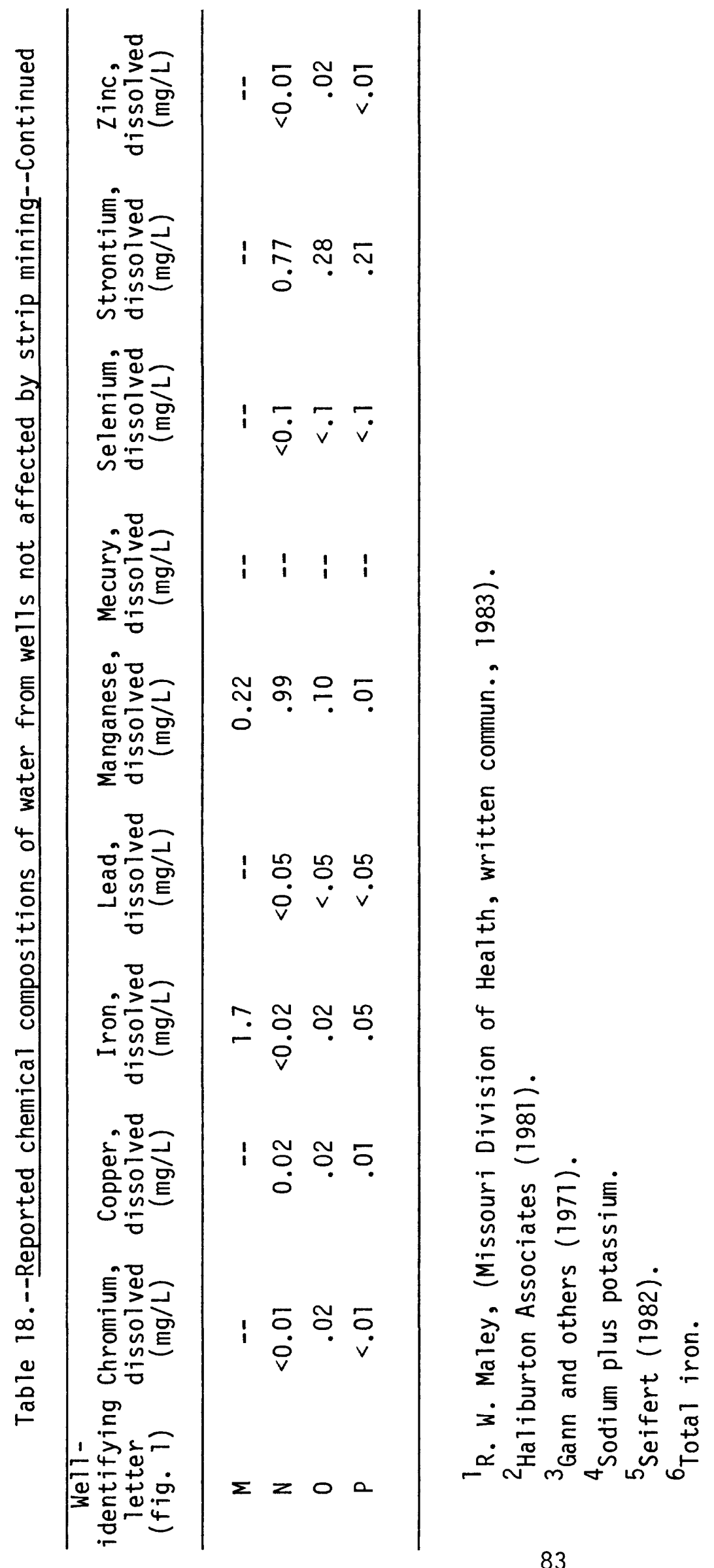


Table 19.--Surface altitudes of and selected quality-of-water data for lakes in spoil areas

[ft, feet; ${ }^{\circ} \mathrm{C}$, degrees Celsius; $\mu \mathrm{S} / \mathrm{cm}$, microsiemens per centimeter at $25^{\circ} \mathrm{Celsius} ; \mathrm{mg} / \mathrm{L}$, milligrams per liter; --, no data; (E), estimated]

\begin{tabular}{|c|c|c|c|c|c|c|c|}
\hline $\begin{array}{l}\text { Lake } \\
\text { number } \\
\text { (figs. } \\
2-4)\end{array}$ & $\begin{array}{c}\text { Date } \\
\text { of } \\
\text { sample }\end{array}$ & $\begin{array}{l}\text { Altitude } \\
\text { of surface } \\
\text { above sea } \\
\text { level } \\
\text { (ft) }\end{array}$ & $\begin{array}{l}\text { Temper- } \\
\text { a ture } \\
\left({ }^{\circ} \mathrm{C}\right)\end{array}$ & $\begin{array}{l}\text { Speci- } \\
\text { fic con- } \\
\text { ductance } \\
(\mu S / c m)\end{array}$ & $\begin{array}{c}\mathrm{pH} \\
\text { (units) }\end{array}$ & $\begin{array}{l}\text { Bicar- } \\
\text { bonate } \\
\text { (mg/L) }\end{array}$ & $\begin{array}{l}\text { Dissolved } \\
\text { oxygen } \\
(\mathrm{mg} / \mathrm{L})\end{array}$ \\
\hline 101 & $\begin{array}{r}3-24-82 \\
6-7-82 \\
9-1-82 \\
6-16-83 \\
6-16-83 \\
6-16-83\end{array}$ & $\begin{array}{l}803.38 \\
804.78(E) \\
805.28 \\
-- \\
-- \\
--\end{array}$ & $\begin{array}{l}10.0 \\
27.0 \\
24.5 \\
24.0 \\
23.0 \\
19.0\end{array}$ & $\begin{array}{l}1,800 \\
2,280 \\
2,700 \\
2,100 \\
3,300 \\
2,760\end{array}$ & $\begin{array}{l}3.2 \\
2.7 \\
3.0 \\
2.8 \\
2.9 \\
2.8\end{array}$ & $\begin{array}{l}0 \\
0 \\
0 \\
-- \\
-- \\
--\end{array}$ & $\begin{array}{l}-- \\
-- \\
-- \\
4.6 \\
4.7 \\
.9\end{array}$ \\
\hline 102 & $\begin{array}{r}3-24-82 \\
6-7-82 \\
9-7-82\end{array}$ & $\begin{array}{l}783.07 \\
782.92 \\
782.79\end{array}$ & $\begin{array}{l}10.5 \\
26.0 \\
25.0\end{array}$ & $\begin{array}{l}750 \\
878 \\
715\end{array}$ & $\begin{array}{l}7.8 \\
7.9 \\
7.8\end{array}$ & $\begin{array}{r}140 \\
130 \\
72\end{array}$ & $\begin{array}{l}-- \\
--\end{array}$ \\
\hline 103 & $\begin{array}{r}3-26-82 \\
6-7-82 \\
9-1-82 \\
1-16-83 \\
6-16-83\end{array}$ & $\begin{array}{c}788.46 \\
788.61 \\
788.45 \\
-- \\
--\end{array}$ & $\begin{array}{r}9.0 \\
28.0 \\
27.0 \\
24.5 \\
20.0\end{array}$ & $\begin{array}{r}860 \\
950 \\
895 \\
1,070 \\
1,600\end{array}$ & $\begin{array}{l}7.9 \\
8.0 \\
8.4 \\
6.4 \\
6.4\end{array}$ & $\begin{array}{r}120 \\
140 \\
74 \\
-- \\
--\end{array}$ & $\begin{array}{l}-- \\
-- \\
-- \\
5.9 \\
3.2\end{array}$ \\
\hline 201 & $\begin{array}{r}3-25-82 \\
6-8-82 \\
9-2-82 \\
7-26-83\end{array}$ & $\begin{array}{l}762.18 \\
761.59 \\
761.83 \\
762.78\end{array}$ & $\begin{array}{l}10.5 \\
15.0 \\
23.0 \\
27.5\end{array}$ & $\begin{array}{l}1,170 \\
2,040 \\
1,150 \\
2,460\end{array}$ & $\begin{array}{l}7.0 \\
7.4 \\
7.3 \\
7.4\end{array}$ & $\begin{array}{l}82 \\
80 \\
40 \\
79\end{array}$ & $\begin{array}{l}-- \\
-- \\
--\end{array}$ \\
\hline 202 & $\begin{array}{r}3-25-82 \\
6-8-82 \\
9-7-82\end{array}$ & $\begin{array}{l}762.82 \\
762.63 \\
762.69\end{array}$ & $\begin{array}{r}9.5 \\
23.0 \\
27.5\end{array}$ & $\begin{array}{l}1,120 \\
1,300 \\
1,080\end{array}$ & $\begin{array}{l}8.2 \\
8.1 \\
8.6\end{array}$ & $\begin{array}{r}120 \\
120 \\
53\end{array}$ & $\begin{array}{l}-- \\
--\end{array}$ \\
\hline 203 & $\begin{array}{r}3-25-82 \\
6-8-82 \\
9-2-82\end{array}$ & $\begin{array}{l}756.42 \\
755.26 \\
756.40\end{array}$ & $\begin{array}{l}11.0 \\
25.0 \\
24.0\end{array}$ & $\begin{array}{l}1,075 \\
1,770 \\
1,070\end{array}$ & $\begin{array}{l}7.6 \\
3.8 \\
4.2\end{array}$ & $\begin{array}{r}18 \\
0 \\
0\end{array}$ & $\begin{array}{l}-- \\
--\end{array}$ \\
\hline 301 & $\begin{array}{r}3-25-82 \\
6-8-82 \\
9-7-82 \\
7-25-83\end{array}$ & $\begin{array}{l}766.79 \\
766.77 \\
767.20 \\
764.78\end{array}$ & $\begin{array}{r}8.5 \\
23.0 \\
24.5 \\
30.0\end{array}$ & $\begin{array}{r}905 \\
1,320 \\
1,180 \\
1,420\end{array}$ & $\begin{array}{l}8.7 \\
8.2 \\
8.1 \\
8.2\end{array}$ & $\begin{array}{l}110 \\
130 \\
110 \\
120\end{array}$ & $\begin{array}{l}-- \\
-- \\
--\end{array}$ \\
\hline 302 & $\begin{array}{r}3-25-82 \\
6-8-82 \\
9-7-82\end{array}$ & $\begin{array}{l}761.02 \\
760.93 \\
761.25\end{array}$ & $\begin{array}{r}8.5 \\
23.0 \\
24.0\end{array}$ & $\begin{array}{l}1,060 \\
1,320 \\
1,360\end{array}$ & $\begin{array}{l}7.8 \\
7.6 \\
7.7\end{array}$ & $\begin{array}{l}110 \\
130 \\
130\end{array}$ & $\begin{array}{l}-- \\
--\end{array}$ \\
\hline
\end{tabular}


Table 19.--Surface altitudes of and selected quality-of-water data for lakes in spoil areas--Continued

$\left[\mathrm{ft}\right.$, feet; ${ }^{\circ} \mathrm{C}$, degrees Celsius; $\mu \mathrm{S} / \mathrm{cm}$, microsiemens per centimeter at $25^{\circ}$ Celsius; mg/L, milligrams per liter; --, no data; (E), estimated]

\begin{tabular}{|c|c|c|c|c|c|c|c|c|}
\hline $\begin{array}{r}\text { Lake } \\
\text { numbe } \\
\text { (figs } \\
2-4 \text { ) }\end{array}$ & & $\begin{array}{c}\text { Date } \\
\text { of } \\
\text { sample }\end{array}$ & $\begin{array}{l}\text { Altitude } \\
\text { of surface } \\
\text { above sea } \\
\text { level } \\
\text { (ft) }\end{array}$ & $\begin{array}{l}\text { Temper- } \\
\text { ature } \\
\left({ }^{\circ} \mathrm{C}\right)\end{array}$ & $\begin{array}{l}\text { Speci- } \\
\text { fic con- } \\
\text { ductance } \\
(\mu S / \mathrm{cm})\end{array}$ & $\begin{array}{c}\mathrm{pH} \\
\text { (units) }\end{array}$ & $\begin{array}{l}\text { Bicar- } \\
\text { bonate } \\
\text { (mg/L) }\end{array}$ & $\begin{array}{l}\text { Dissolved } \\
\text { oxygen } \\
\text { (mg/L) }\end{array}$ \\
\hline 303 & & $\begin{array}{r}3-25-82 \\
6-8-82 \\
9-1-82\end{array}$ & $\begin{array}{l}753.98 \\
753.36 \\
753.59\end{array}$ & $\begin{array}{r}9.0 \\
22.0 \\
24.5\end{array}$ & $\begin{array}{l}1,210 \\
1,320 \\
1,280\end{array}$ & $\begin{array}{l}8.2 \\
8.5 \\
8.2\end{array}$ & $\begin{array}{l}95 \\
67 \\
77\end{array}$ & $\begin{array}{l}-- \\
-- \\
--\end{array}$ \\
\hline 100 & $\begin{array}{l}A \\
B \\
C \\
D \\
E \\
F \\
G\end{array}$ & $\begin{array}{c}8-10-83 \\
--d o-- \\
--d 0-- \\
--d 0-- \\
--d 0-- \\
--d 0-- \\
--d o--\end{array}$ & $\begin{array}{l}786.19 \\
791.12 \\
797.21 \\
778.69 \\
789.72 \\
810.64 \\
810.68\end{array}$ & $\begin{array}{l}26.0 \\
31.0 \\
32.0 \\
32.0 \\
31.5 \\
32.0 \\
32.5\end{array}$ & $\begin{array}{r}2,560 \\
540 \\
775 \\
2,450 \\
2,150 \\
920 \\
320\end{array}$ & $\begin{array}{l}7.1 \\
8.3 \\
7.8 \\
8.1 \\
3.2 \\
3.4 \\
8.5\end{array}$ & $\begin{array}{l}-- \\
-- \\
-- \\
-- \\
-- \\
--\end{array}$ & $\begin{array}{l}-- \\
-- \\
-- \\
-- \\
-- \\
-- \\
--\end{array}$ \\
\hline 200 & $\begin{array}{l}A \\
B \\
C\end{array}$ & $\begin{array}{l}8-9-83 \\
-- \text { do-- } \\
-- \text { do }--\end{array}$ & $\begin{array}{l}760.08 \\
751.22 \\
749.85\end{array}$ & $\begin{array}{l}35.0 \\
36.0 \\
30.0\end{array}$ & $\begin{array}{l}3,100 \\
5,300 \\
1,545\end{array}$ & $\begin{array}{l}7.6 \\
2.8 \\
7.6\end{array}$ & $\begin{array}{l}-- \\
-- \\
--\end{array}$ & $\begin{array}{l}-- \\
-- \\
--\end{array}$ \\
\hline 300 & $\begin{array}{l}A \\
B \\
C \\
D \\
E \\
F \\
G \\
H\end{array}$ & $\begin{array}{r}8-11-83 \\
--d 0-- \\
--d 0-- \\
--d 0-- \\
--d 0-- \\
--d 0-- \\
--d 0-- \\
8-12-83\end{array}$ & $\begin{array}{l}742.96 \\
759.92 \\
749.89 \\
769.81 \\
769.84 \\
787.40 \\
787.84 \\
791.88\end{array}$ & $\begin{array}{l}25.5 \\
30.0 \\
29.0 \\
30.0 \\
30.5 \\
31.0 \\
29.5 \\
27.5\end{array}$ & $\begin{array}{r}3,780 \\
3,280 \\
4,350 \\
2,980 \\
3,480 \\
580 \\
1,400 \\
180\end{array}$ & $\begin{array}{l}7.9 \\
8.1 \\
7.8 \\
8.3 \\
8.0 \\
8.6 \\
8.0 \\
8.2\end{array}$ & $\begin{array}{l}-- \\
-- \\
-- \\
-- \\
-- \\
-- \\
-- \\
64\end{array}$ & $\begin{array}{l}-- \\
-- \\
-- \\
-- \\
-- \\
-- \\
-- \\
--\end{array}$ \\
\hline
\end{tabular}




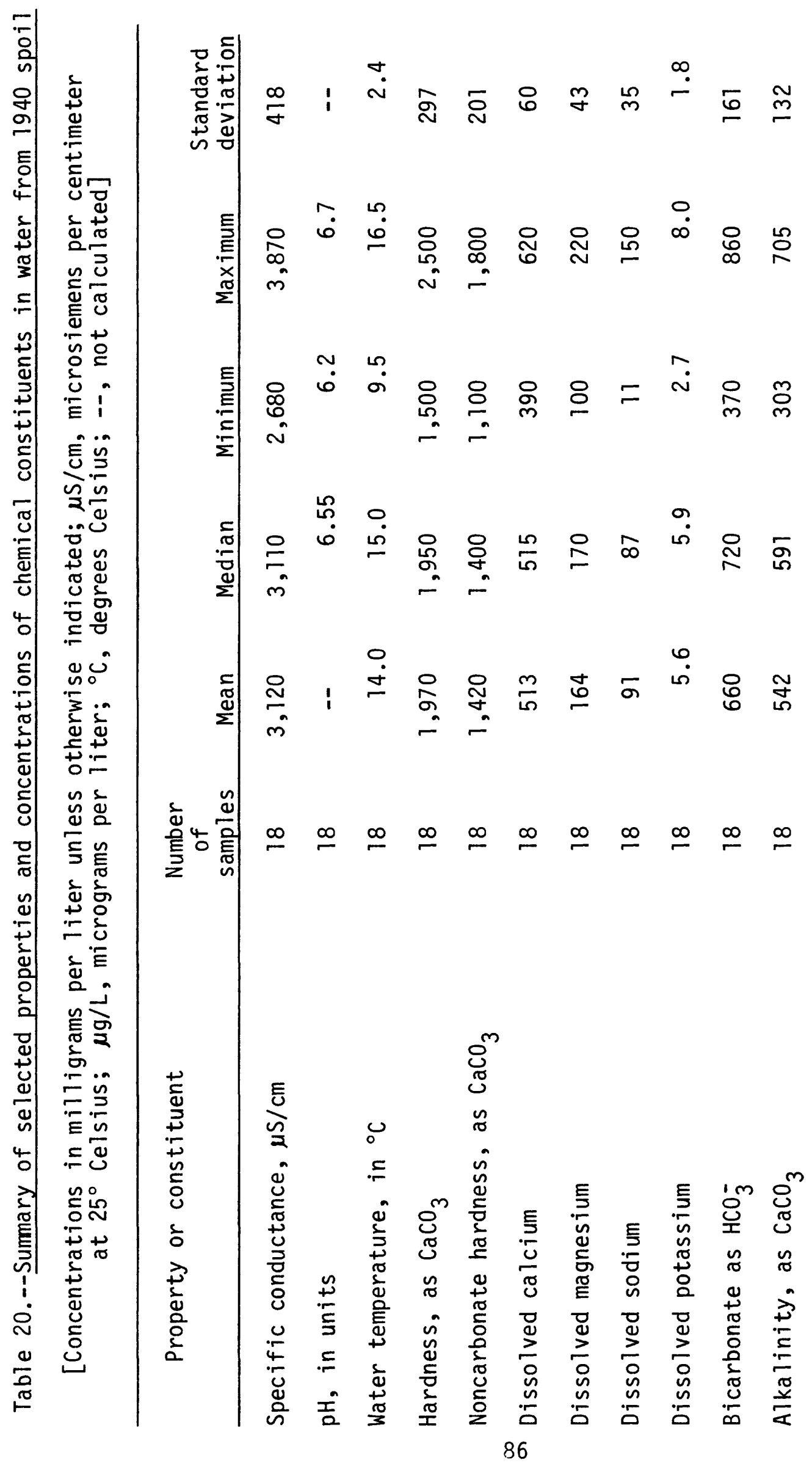




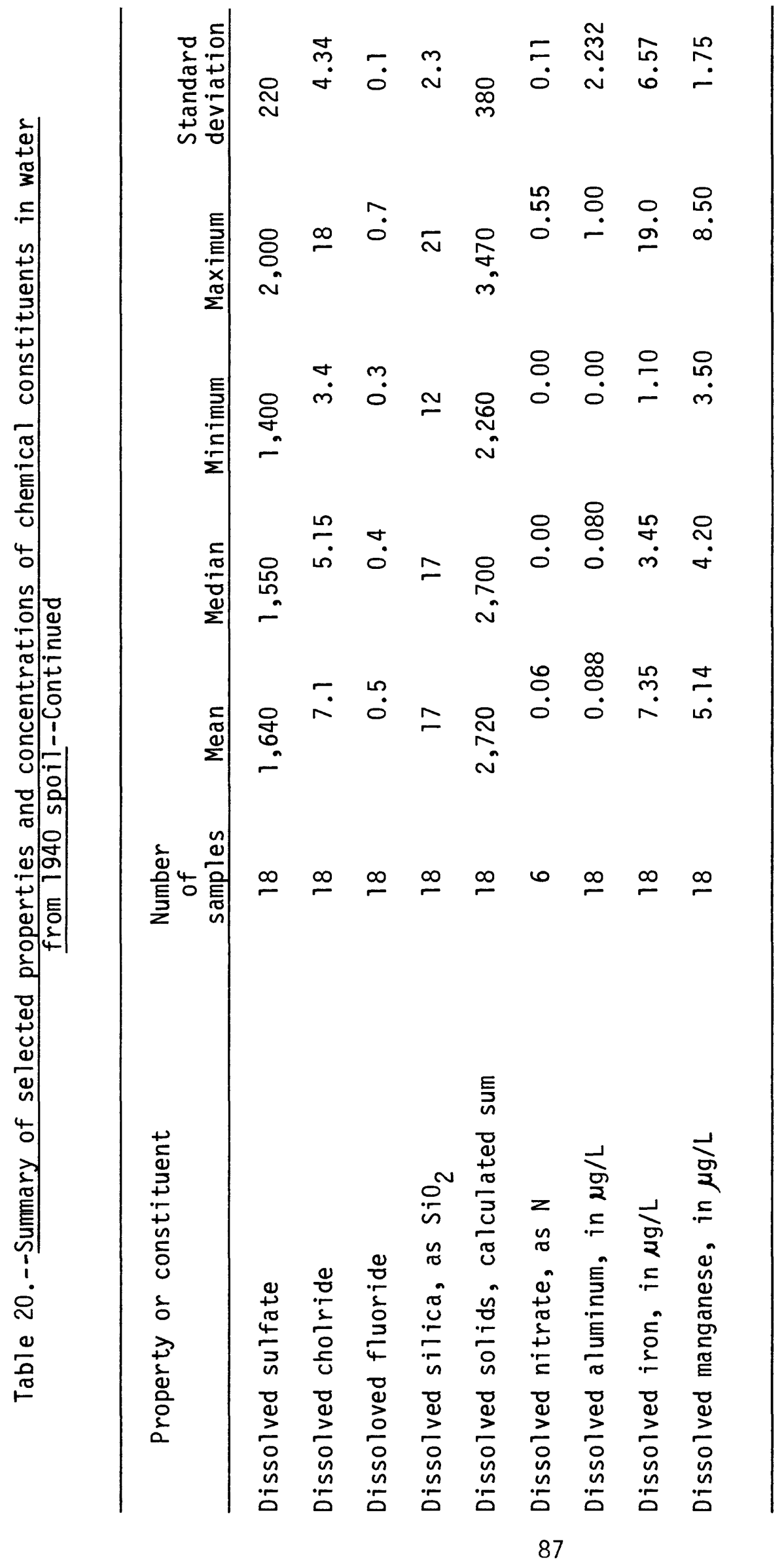




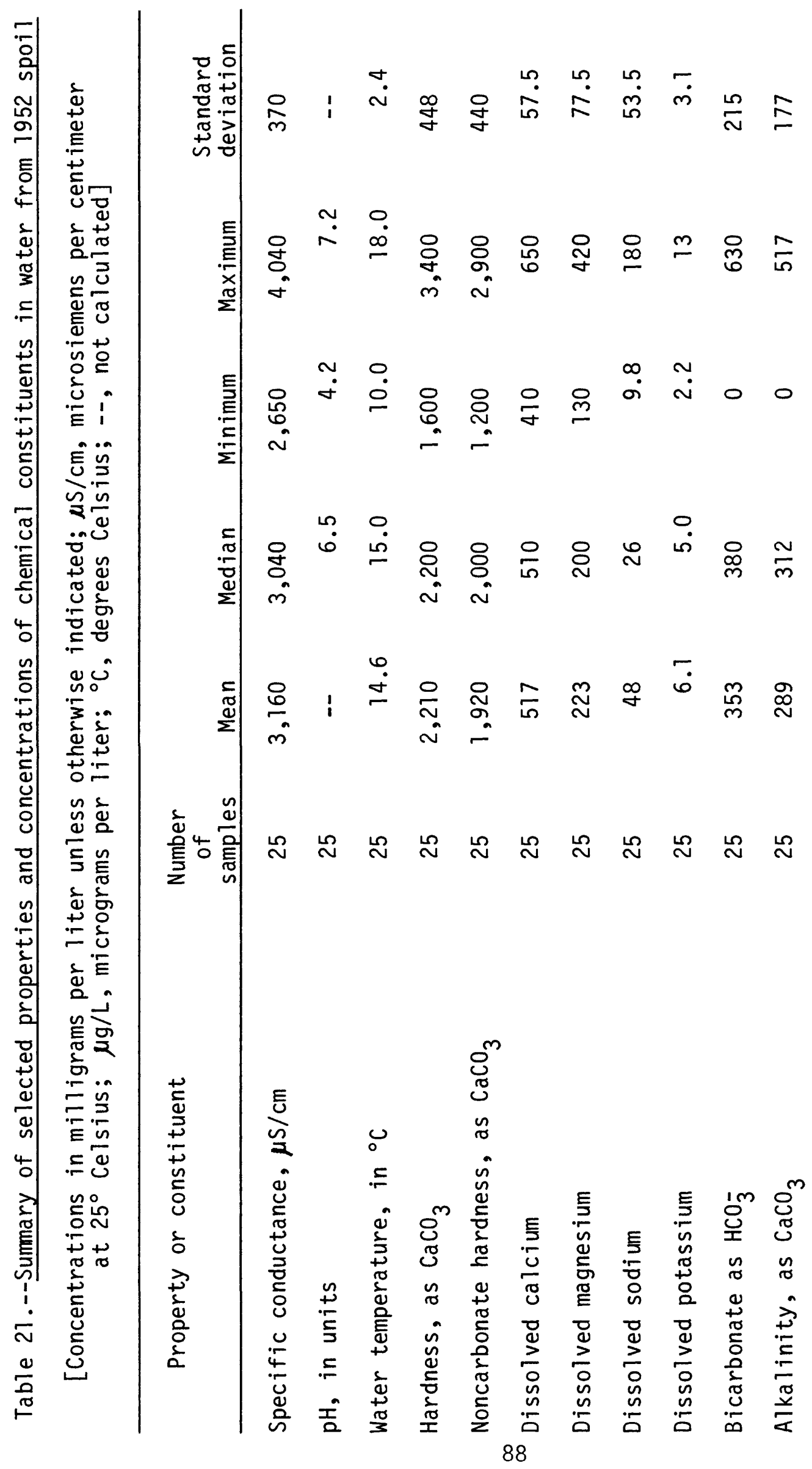




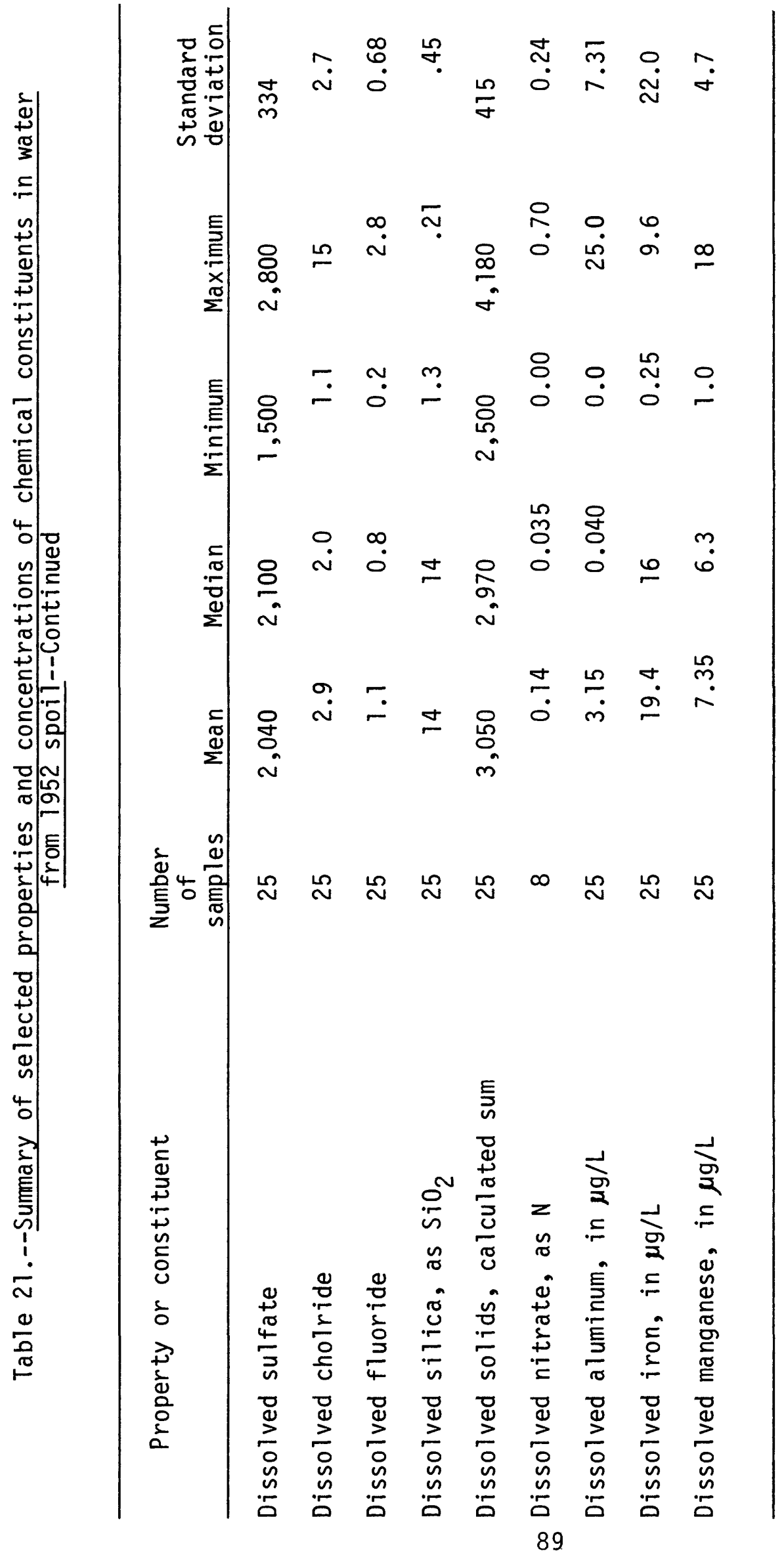




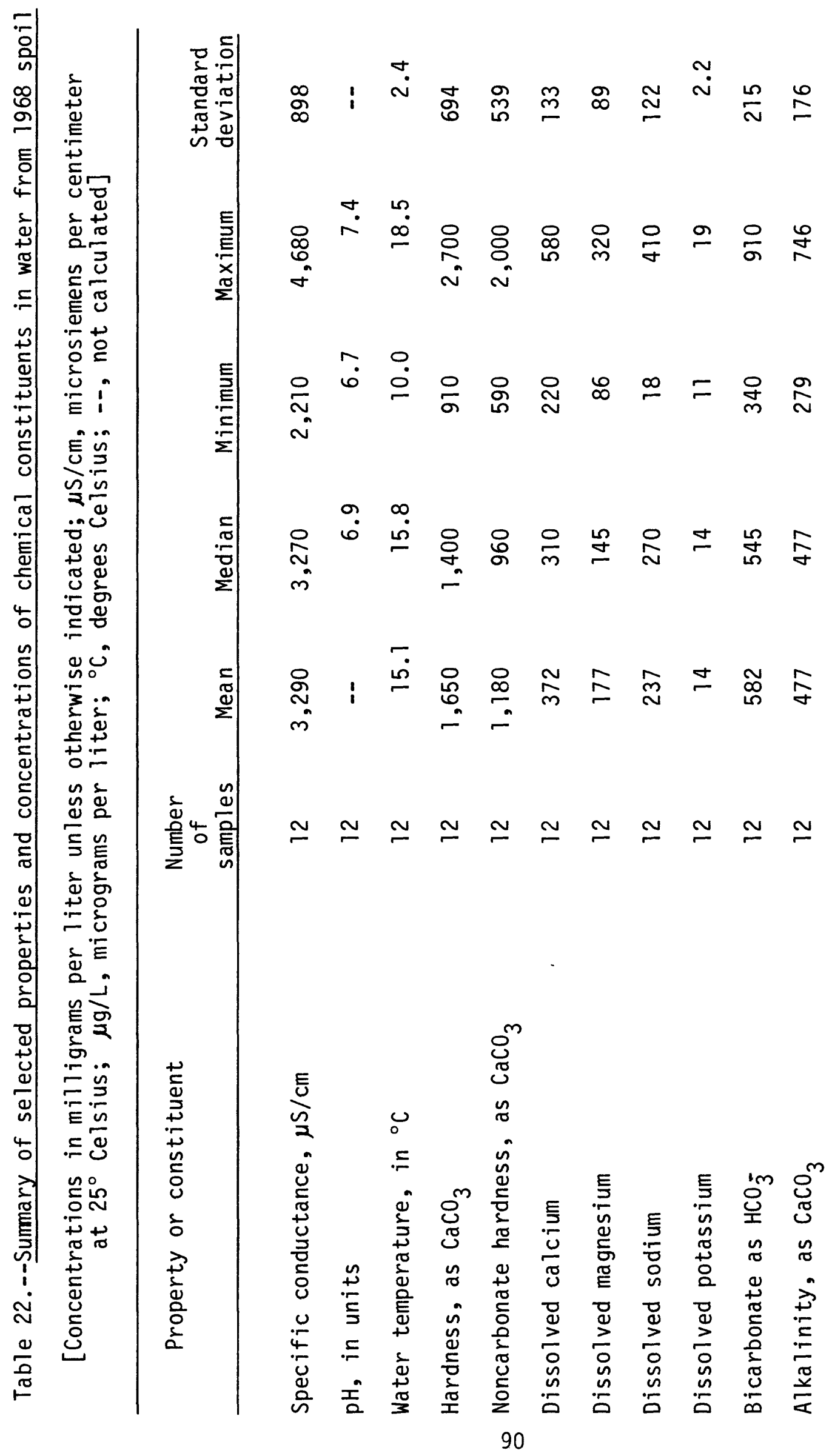




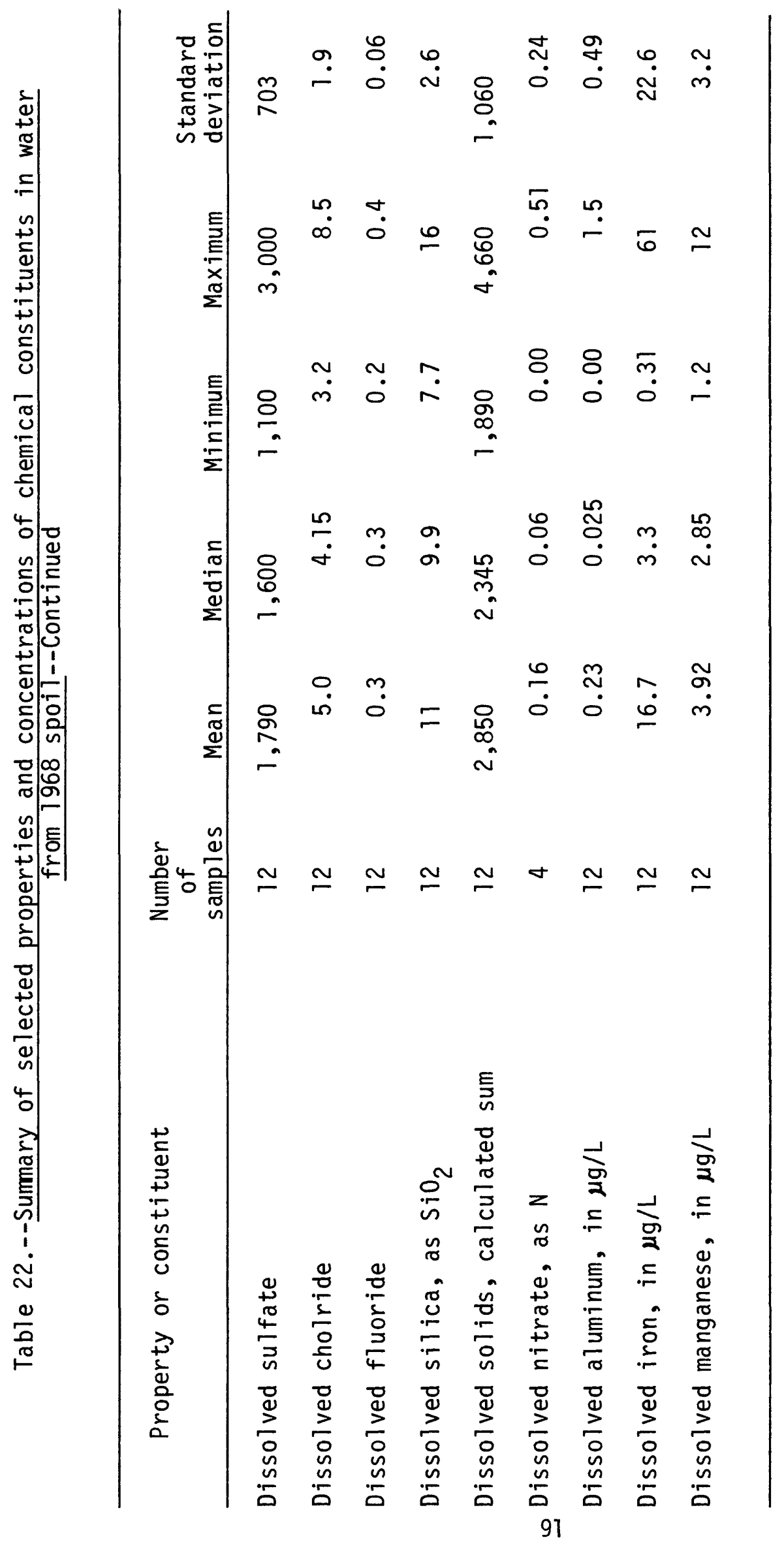



Table 23.--Saturation indices of selected minerals in water

$[--$ not calculated]

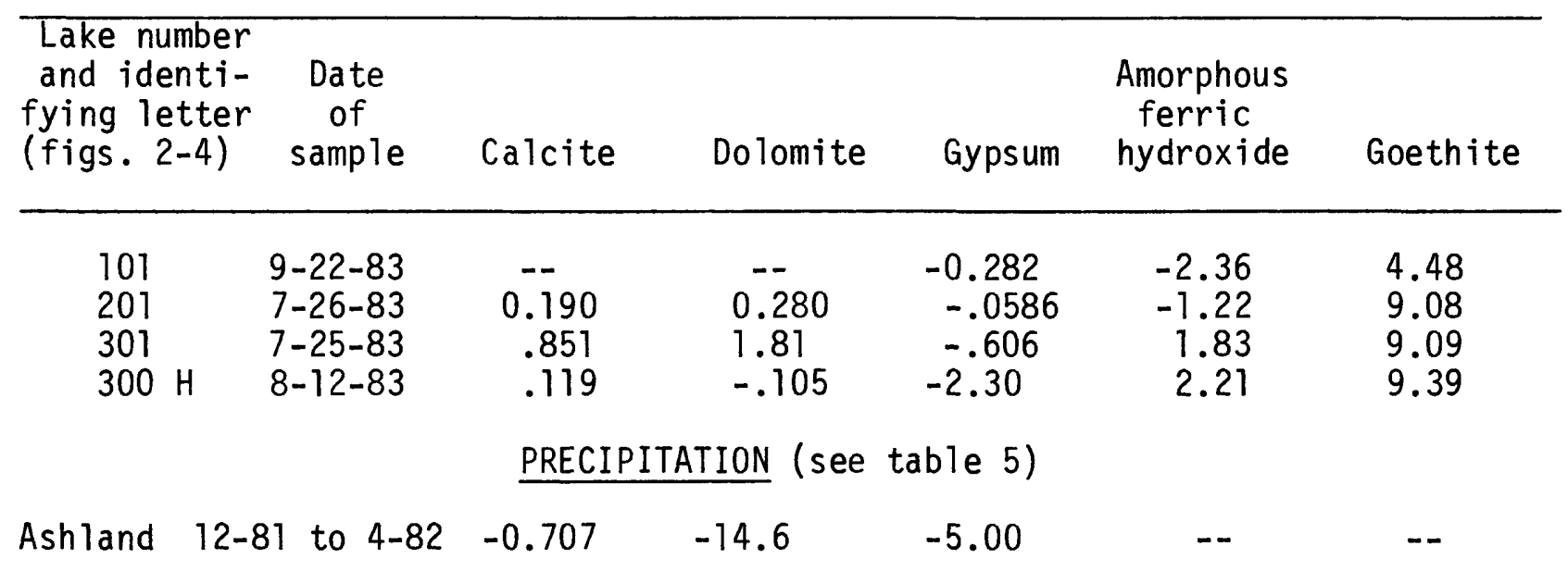

\begin{tabular}{|c|c|c|c|c|c|c|c|c|}
\hline $\begin{array}{l}\text { Lake } \\
\text { number } \\
\text { and } \\
\text { identi- } \\
\text { fying } \\
\text { letter } \\
\text { (figs. } \\
2-4 \text { ) }\end{array}$ & $\begin{array}{c}\text { Date } \\
\text { of } \\
\text { sample }\end{array}$ & Alunite & Albite & Adularia & Kaolinite & $\begin{array}{l}\text { Amorphous } \\
\text { ferric } \\
\text { hydroxide }\end{array}$ & Pyrite & Siderite \\
\hline $\begin{array}{l}101 \\
201 \\
301 \\
300 \mathrm{H}\end{array}$ & $\begin{array}{l}9-22-83 \\
7-26-83 \\
7-25-83 \\
8-12-83\end{array}$ & $\begin{array}{l}-7.21 \\
-2.62 \\
-9.09 \\
-10.4\end{array}$ & $\begin{array}{l}-.- \\
-2.43 \\
-4.40 \\
-5.38 \\
\text { PRECIPI }\end{array}$ & $\begin{array}{c}-- \\
-.724 \\
-3.16 \\
-3.40 \\
\text { TATION }\end{array}$ & $\begin{array}{r}1.54 \\
-2.14 \\
-1.42 \\
\text { see table }\end{array}$ & $\begin{array}{ll} & -8.22 \\
& -1.42 \\
& -2.57 \\
& -2.14 \\
& \end{array}$ & $\begin{array}{l}-- \\
-- \\
--\end{array}$ & $\begin{array}{l}-- \\
-27.7 \\
-29.2 \\
-29.0\end{array}$ \\
\hline Ashland & $\begin{array}{c}12-81 \\
\text { to } 4-82\end{array}$ & -- & - & -- & -- & -- & -- & -- \\
\hline
\end{tabular}


Table 23.--Saturation indices of selected minerals in water from selected lakes and precipitation--Continued

\begin{tabular}{|c|c|c|c|c|}
\hline $\begin{array}{l}\text { Lake number } \\
\text { and identi- } \\
\text { fying letter } \\
\text { (figs. 2-4) }\end{array}$ & $\begin{array}{l}\text { Date } \\
\text { of } \\
\text { sample }\end{array}$ & Quartz & Illite & $\begin{array}{l}\text { Calcium } \\
\text { montmo- } \\
\text { rillonite }\end{array}$ \\
\hline \multirow[t]{2}{*}{$\begin{array}{l}101 \\
201 \\
301 \\
300 \mathrm{H}\end{array}$} & $\begin{array}{l}9-22-83 \\
7-26-83 \\
7-25-83 \\
8-12-83\end{array}$ & $\begin{array}{l}-\overline{-} \\
0.368 \\
-.301 \\
-.390\end{array}$ & $\begin{array}{l}0.535 \\
-3.66 \\
-3.46\end{array}$ & $\begin{array}{l}-\overline{-} \\
0.990 \\
-3.95 \\
-3.35\end{array}$ \\
\hline & \multicolumn{4}{|c|}{ PRECIPITATION (see table 5) } \\
\hline Ashland & $2-81-4-82$ & -- & -- & -- \\
\hline
\end{tabular}


Table 24.--Saturation indices of selected minerals in water from wells completed in glacial drift and bedrock not affected by strip mines

$$
[--, \text { not calculated] }
$$

\begin{tabular}{|c|c|c|c|c|c|c|}
\hline $\begin{array}{l}\text { Well-identi- } \\
\text { fying letter } \\
\text { (fig. 1) }\end{array}$ & $\begin{array}{c}\text { Date } \\
\text { of } \\
\text { sample }\end{array}$ & Calcite & Dolomite & Gypsum & $\begin{array}{l}\text { Amorphous } \\
\text { ferric } \\
\text { hydroxide }\end{array}$ & Goethite \\
\hline
\end{tabular}

WELLS COMPLETED IN GLACIAL DRIFT

\begin{tabular}{|c|c|c|c|c|c|c|}
\hline$A$ & $\begin{array}{r}10-11-80 \\
10-9-80 \\
10-20-80 \\
10-2-80 \\
10-20-80\end{array}$ & $\begin{array}{c}0.160 \\
-.048 \\
.092 \\
-.289 \\
.0407\end{array}$ & $\begin{array}{c}0.116 \\
-.485 \\
-.104 \\
-1.11 \\
.471\end{array}$ & $\begin{array}{l}-1.65 \\
-- \\
-1.11 \\
-1.31 \\
-1.59\end{array}$ & $\begin{array}{l}3.53 \\
3.46 \\
2.03 \\
1.92 \\
3.52\end{array}$ & $\begin{array}{c}10.2 \\
10.7 \\
8.71 \\
8.61 \\
10.2\end{array}$ \\
\hline $\begin{array}{l}F \\
G\end{array}$ & $\begin{array}{r}9-2-80 \\
9-23-80 \\
10-22-80 \\
9-14-80 \\
2-26-80\end{array}$ & $\begin{array}{c}.159 \\
-.192 \\
.0224 \\
.252 \\
.531\end{array}$ & $\begin{array}{r}.109 \\
-.907 \\
-.281 \\
-.337 \\
.358\end{array}$ & $\begin{array}{l}-1.97 \\
-.840 \\
-.926 \\
-2.21 \\
-.394\end{array}$ & $\begin{array}{l}2.62 \\
2.91 \\
2.26 \\
2.22 \\
--\end{array}$ & $\begin{array}{l}9.30 \\
9.59 \\
8.94 \\
8.90 \\
--\end{array}$ \\
\hline $\begin{array}{l}K \\
1\end{array}$ & $\begin{array}{r}2-26-80 \\
3-16-66 \\
3-15-66 \\
4-9-81 \\
9-15-81\end{array}$ & $\begin{array}{l}.688 \\
.419 \\
.599 \\
.516 \\
.817\end{array}$ & $\begin{array}{l}.990 \\
.517 \\
1.03 \\
.799 \\
.023\end{array}$ & $\begin{array}{l}-1.04 \\
-1.38 \\
-2.20 \\
-.871 \\
-.744\end{array}$ & $\begin{array}{l}2.35 \\
3.25 \\
3.34 \\
-- \\
2.65\end{array}$ & $\begin{array}{c}8.92 \\
9.93 \\
10.0 \\
-- \\
9.33\end{array}$ \\
\hline T & $\begin{array}{l}8-24-83 \\
8-24-83 \\
8-25-83\end{array}$ & $\begin{array}{r}-.428 \\
.174 \\
.456\end{array}$ & $\begin{array}{r}-1.24 \\
-.247 \\
.603\end{array}$ & $\begin{array}{l}-1.84 \\
-1.46 \\
-2.37\end{array}$ & $\begin{array}{l}1.30 \\
2.20 \\
2.55\end{array}$ & $\begin{array}{l}8.06 \\
8.92 \\
9.49\end{array}$ \\
\hline
\end{tabular}

WELLS COMPLETED IN BEDROCK

$\begin{array}{lrlllll}0 & 4-9-81 & 0.428 & 0.358 & -1.31 & 1.50 & 8.19 \\ \mathrm{P} & 4-9-81 & 1.20 & 2.68 & -2.44 & .580 & 7.31 \\ \mathrm{R} & 9-15-81 & .177 & .270 & -1.83 & 1.49 & 8.18 \\ \mathrm{~S} & 9-15-81 & 1.05 & 1.67 & -4.31 & -.313 & 6.37\end{array}$


Table 24.--Saturation indices of selected minerals in water from wells completed in glacial drift and bedrock not affected by strip mines--Continued

We11-

identi-

fying Date

Amphorous

letter

of

a luminum

(fig. 1) sample Alunite Albite Adularia Kaolinite hydroxide Pyrite Siderite

WELLS COMPLETED IN GLACIAL DRIFT

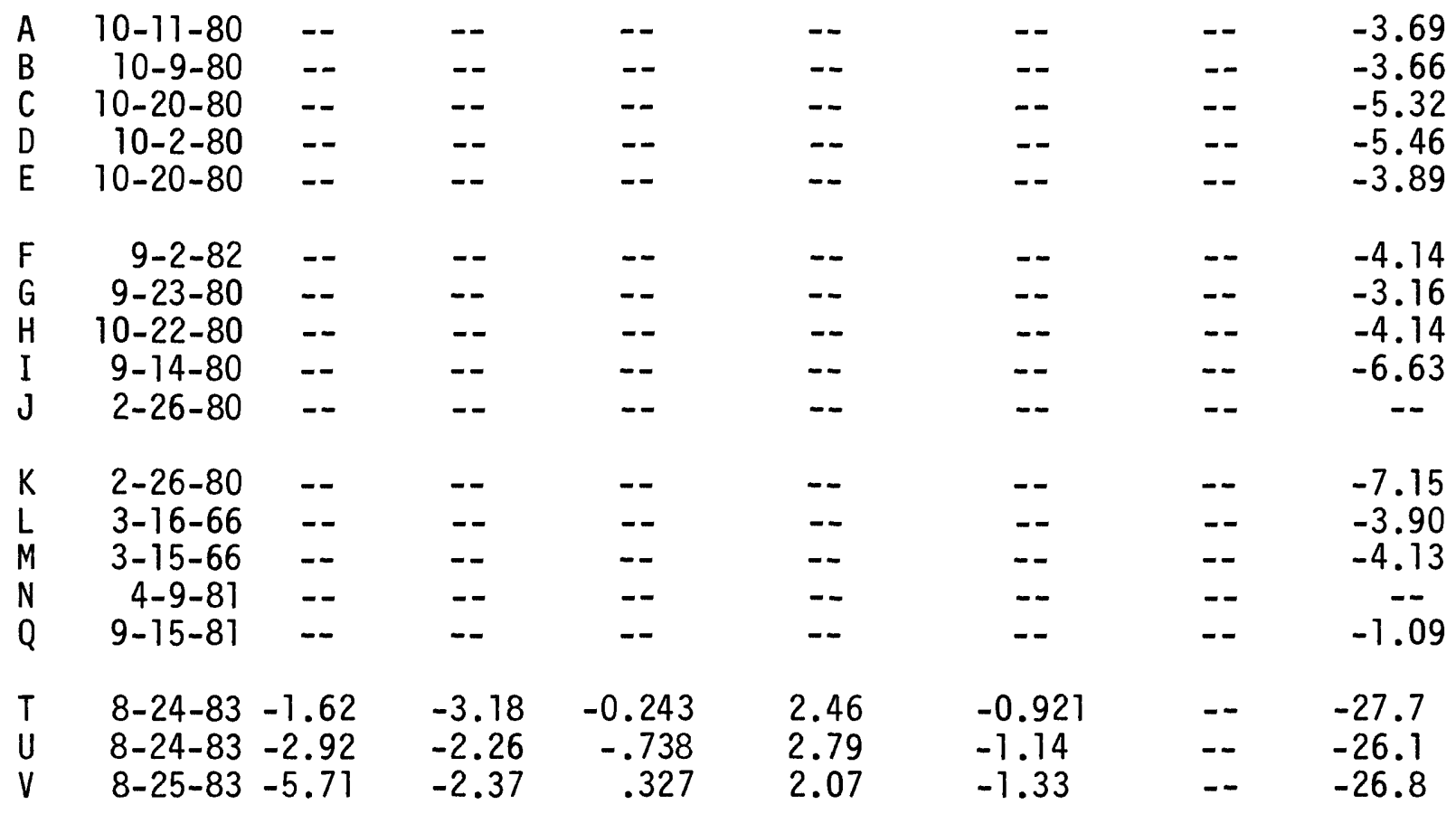

WELLS COMPLETED IN BEDROCK

$\begin{array}{lrlllllll}0 & 4-9-81 & -- & -- & -- & -- & -- & -- & -6.69 \\ P & 4-9-81 & -- & -- & -- & -- & -- & -- & -10.3 \\ R & 9-15-81 & -- & -- & -- & -- & -- & -- & -5.01 \\ \text { S } & 9-15-81 & -- & -- & -- & -- & -- & -- & -13.8\end{array}$


Table 24.--Saturation indices of selected minerals in water from wells completed in glacial drift and bedrock not affected by strip mines--Continued

\begin{tabular}{|c|c|c|c|c|}
\hline $\begin{array}{l}\text { Well-identi- } \\
\text { fying letter } \\
\text { (fig. 1) }\end{array}$ & $\begin{array}{l}\text { Date } \\
\text { of } \\
\text { sample }\end{array}$ & Quartz & Il1ite & $\begin{array}{l}\text { Calcium } \\
\text { montmo- } \\
\text { rillonite }\end{array}$ \\
\hline \multicolumn{5}{|c|}{ WELLS COMPLETED IN GLACIAL DRIFT } \\
\hline $\begin{array}{l}A \\
B \\
C \\
D \\
E\end{array}$ & $\begin{array}{r}10-11-80 \\
10-9-80 \\
10-20-80 \\
10-2-80 \\
10-20-80\end{array}$ & $\begin{array}{l}-- \\
-- \\
-- \\
-- \\
--\end{array}$ & $\begin{array}{l}-- \\
-- \\
-- \\
-- \\
--\end{array}$ & $\begin{array}{l}-- \\
-- \\
-- \\
-- \\
--\end{array}$ \\
\hline $\begin{array}{l}F \\
G \\
H \\
I \\
J\end{array}$ & $\begin{array}{r}9-2-80 \\
9-23-80 \\
10-22-80 \\
9-14-80 \\
2-26-80\end{array}$ & $\begin{array}{l}-- \\
-- \\
-- \\
-- \\
--\end{array}$ & $\begin{array}{l}-- \\
-- \\
-- \\
-- \\
--\end{array}$ & $\begin{array}{l}-- \\
-- \\
-- \\
-- \\
--\end{array}$ \\
\hline $\begin{array}{l}K \\
L \\
M \\
N \\
Q\end{array}$ & $\begin{array}{r}2-26-80 \\
3-16-66 \\
3-15-66 \\
4-9-81 \\
9-15-81\end{array}$ & $\begin{array}{r}-- \\
0.578 \\
.401 \\
.910 \\
.746\end{array}$ & $\begin{array}{l}-- \\
-- \\
-- \\
-- \\
--\end{array}$ & $\begin{array}{l}-- \\
-- \\
-- \\
-- \\
--\end{array}$ \\
\hline \multirow[t]{2}{*}{$\begin{array}{l}T \\
U \\
V\end{array}$} & $\begin{array}{l}8-24-83 \\
8-24-83 \\
8-25-83\end{array}$ & $\begin{array}{l}.238 \\
.616 \\
.492\end{array}$ & $\begin{array}{l}1.19 \\
1.11 \\
1.47\end{array}$ & $\begin{array}{l}1.54 \\
2.41 \\
1.64\end{array}$ \\
\hline & WELLS & COMPLETED IN & BEDROCK & \\
\hline $\begin{array}{l}0 \\
P \\
R \\
S\end{array}$ & $\begin{array}{r}4-9-81 \\
4-9-81 \\
9-15-81 \\
9-15-81\end{array}$ & $\begin{array}{r}0.844 \\
.569 \\
.479 \\
-.197\end{array}$ & $\begin{array}{l}-- \\
-- \\
-- \\
--\end{array}$ & $\begin{array}{l}-- \\
-- \\
-- \\
--\end{array}$ \\
\hline
\end{tabular}


Table 25.--Saturation indices of selected minerals in water from we1ls completed in or near spoil

$[--$, not calculated $]$

\begin{tabular}{|c|c|c|c|c|c|c|}
\hline $\begin{array}{c}\text { We11 } \\
\text { number } \\
\text { (figs. 2-4) }\end{array}$ & $\begin{array}{c}\text { Date } \\
\text { of } \\
\text { sample }\end{array}$ & Calcite & Dolomite & Gypsum & $\begin{array}{c}\text { Amorphous } \\
\text { ferric } \\
\text { hydroxide }\end{array}$ & Goethite \\
\hline 1 & $\begin{array}{r}7-21-81 \\
12-8-81 \\
3-24-82 \\
6-7-82 \\
9-1-82\end{array}$ & $\begin{array}{l}0.174 \\
-.151 \\
-.052 \\
-.236 \\
-.037\end{array}$ & $\begin{array}{r}-0.103 \\
-.684 \\
-.500 \\
-.877 \\
-.488\end{array}$ & $\begin{array}{r}0.038 \\
-.009 \\
.044 \\
.053 \\
.060\end{array}$ & $\begin{array}{l}-4.14 \\
-4.87 \\
-4.64 \\
-8.72 \\
-4.84\end{array}$ & $\begin{array}{l}2.04 \\
1.75 \\
2.08 \\
1.56 \\
1.91\end{array}$ \\
\hline 2 & $\begin{array}{r}12-8-81 \\
3-24-82 \\
6-7-82 \\
9-1-82\end{array}$ & $\begin{array}{r}-0.183 \\
.112 \\
-.018 \\
.198\end{array}$ & $\begin{array}{r}-0.546 \\
.013 \\
-.245 \\
.190\end{array}$ & $\begin{array}{r}-0.044 \\
.094 \\
.098 \\
.077\end{array}$ & $\begin{array}{l}-6.21 \\
-5.51 \\
-5.82 \\
-5.32\end{array}$ & $\begin{array}{l}0.399 \\
1.09 \\
.898 \\
1.42\end{array}$ \\
\hline 3 & $\begin{array}{r}7-20-81 \\
12-9-81 \\
3-26-82 \\
6-7-82 \\
8-31-82 \\
7-26-83\end{array}$ & $\begin{array}{r}-0.141 \\
.235 \\
.255 \\
-.114 \\
-.040 \\
.362\end{array}$ & $\begin{array}{r}-0.492 \\
.235 \\
.231 \\
-.441 \\
-.287 \\
.539\end{array}$ & $\begin{array}{r}0.034 \\
.131 \\
.166 \\
.174 \\
.170 \\
.152\end{array}$ & $\begin{array}{l}-5.94 \\
-5.35 \\
-5.67 \\
-6.36 \\
-6.11 \\
-5.44\end{array}$ & $\begin{array}{l}0.839 \\
1.22 \\
.835 \\
.403 \\
.645 \\
1.32\end{array}$ \\
\hline 4 & $\begin{array}{r}12-9-81 \\
3-24-82 \\
6-7-82 \\
9-1-82\end{array}$ & $\begin{array}{r}0.095 \\
.043 \\
.015 \\
.185\end{array}$ & $\begin{array}{r}-0.172 \\
-.250 \\
-.317 \\
.041\end{array}$ & $\begin{array}{l}0.100 \\
.121 \\
.083 \\
.068\end{array}$ & $\begin{array}{l}-6.09 \\
-5.60 \\
-5.91 \\
-5.59\end{array}$ & $\begin{array}{c}0.458 \\
.986 \\
.832 \\
1.13\end{array}$ \\
\hline 6 & $\begin{array}{r}7-21-81 \\
3-25-82 \\
6-8-82 \\
9-2-82\end{array}$ & $\begin{array}{r}0.372 \\
.549 \\
.360 \\
.427\end{array}$ & $\begin{array}{l}0.636 \\
1.02 \\
.713 \\
.869\end{array}$ & $\begin{array}{r}0.041 \\
.186 \\
.189 \\
.142\end{array}$ & $\begin{array}{l}-4.24 \\
-2.68 \\
-3.20 \\
-3.12\end{array}$ & $\begin{array}{l}2.61 \\
3.96 \\
3.56 \\
3.65\end{array}$ \\
\hline 7 & $\begin{array}{r}7-21-81 \\
12-9-81 \\
3-25-82 \\
6-8-82 \\
9-2-82\end{array}$ & $\begin{array}{l}0.002 \\
-.397 \\
-.175 \\
-.110 \\
-.173\end{array}$ & $\begin{array}{l}-0.055 \\
-1.54 \\
-.529 \\
-.321 \\
-.506\end{array}$ & $\begin{array}{r}0.122 \\
.192 \\
.145 \\
.145 \\
.144\end{array}$ & $\begin{array}{l}-4.59 \\
-4.89 \\
-3.70 \\
-.870 \\
-4.24\end{array}$ & $\begin{array}{l}2.23 \\
1.64 \\
2.88 \\
3.00 \\
2.48\end{array}$ \\
\hline 8 & $\begin{array}{r}7-21-81 \\
12-9-81 \\
3-25-82 \\
6-8-82 \\
9-2-82 \\
7-26-83\end{array}$ & $\begin{array}{r}-0.122 \\
.153 \\
.453 \\
.197 \\
.247 \\
.044\end{array}$ & $\begin{array}{r}-0.501 \\
.003 \\
.611 \\
.137 \\
.359 \\
-.178\end{array}$ & $\begin{array}{r}-0.012 \\
.056 \\
.025 \\
.052 \\
.022 \\
.013\end{array}$ & $\begin{array}{l}-6.65 \\
-5.79 \\
-5.13 \\
-5.25 \\
-5.20 \\
-1.29\end{array}$ & $\begin{array}{l}0.123 \\
.735 \\
1.59 \\
1.58 \\
1.50 \\
1.45\end{array}$ \\
\hline
\end{tabular}


Table 25.--Saturation indices of selected minerals in water from wells completed in or near spoil--Continued

\begin{tabular}{|c|c|c|c|c|c|c|}
\hline $\begin{array}{c}\text { Wel1 } \\
\text { number } \\
\text { (figs. 2-4) }\end{array}$ & $\begin{array}{c}\text { Date } \\
\text { of } \\
\text { sample }\end{array}$ & Calcite & Dolomite & Gypsum & $\begin{array}{c}\text { Amorphous } \\
\text { ferric } \\
\text { hydroxide }\end{array}$ & Goethite \\
\hline 9 & $\begin{array}{r}12-9-81 \\
3-25-82 \\
6-8-82 \\
9-1-82\end{array}$ & $\begin{array}{r}-0.059 \\
.533 \\
-.279 \\
-.115\end{array}$ & $\begin{array}{c}-0.282 \\
1.11 \\
-.492 \\
-.157\end{array}$ & $\begin{array}{r}0.070 \\
.260 \\
.201 \\
.206\end{array}$ & $\begin{array}{l}-4.52 \\
-5.23 \\
-5.91 \\
-5.57\end{array}$ & $\begin{array}{l}2.08 \\
1.47 \\
.829 \\
1.21\end{array}$ \\
\hline 10 & $\begin{array}{r}3-25-82 \\
6-8-82 \\
9-1-82\end{array}$ & $\begin{array}{l}0.220 \\
-.278 \\
-.298\end{array}$ & $\begin{array}{l}0.275 \\
-.705 \\
-.769\end{array}$ & $\begin{array}{r}0.187 \\
.157 \\
.149\end{array}$ & $\begin{array}{l}-6.03 \\
-6.53 \\
-6.43\end{array}$ & $\begin{array}{r}0.578 \\
.190 \\
.400\end{array}$ \\
\hline 11 & $7-21-81$ & 0.002 & -0.178 & -0.306 & -5.15 & 1.59 \\
\hline 12 & $\begin{array}{r}7-21-81 \\
3-25-82 \\
6-8-82 \\
9-1-82 \\
7-25-83\end{array}$ & $\begin{array}{r}0.145 \\
.412 \\
.090 \\
-.154 \\
.066\end{array}$ & $\begin{array}{r}0.176 \\
.758 \\
.073 \\
-.397 \\
.029\end{array}$ & $\begin{array}{r}-0.021 \\
-.026 \\
-.197 \\
-.158 \\
-.181\end{array}$ & $\begin{array}{l}-5.16 \\
-4.32 \\
-5.12 \\
-5.56 \\
-5.58\end{array}$ & $\begin{array}{l}1.63 \\
2.27 \\
1.62 \\
1.21 \\
1.22\end{array}$ \\
\hline 13 & $\begin{array}{r}3-25-82 \\
6-8-82 \\
9-1-82\end{array}$ & $\begin{array}{r}0.360 \\
.162 \\
-.103\end{array}$ & $\begin{array}{r}0.425 \\
.096 \\
-.396\end{array}$ & $\begin{array}{r}-0.174 \\
-.191 \\
-.231\end{array}$ & $\begin{array}{l}-5.01 \\
-5.69 \\
-5.91\end{array}$ & $\begin{array}{l}1.52 \\
1.05 \\
.852\end{array}$ \\
\hline 14 & $\begin{array}{r}12-9-81 \\
3-25-82 \\
6-8-82 \\
9-2-82\end{array}$ & $\begin{array}{l}-0.411 \\
-2.05 \\
-1.42 \\
-.992\end{array}$ & $\begin{array}{l}-0.965 \\
-4.42 \\
-3.03 \\
-2.21\end{array}$ & $\begin{array}{r}0.073 \\
.195 \\
.171 \\
.151\end{array}$ & $\begin{array}{l}-4.32 \\
-6.70 \\
-6.03 \\
-5.47\end{array}$ & $\begin{array}{l}2.40 \\
-.131 \\
.710 \\
1.28\end{array}$ \\
\hline 15 & $\begin{array}{r}12-9-81 \\
3-25-82 \\
6-8-82 \\
9-2-82\end{array}$ & $\begin{array}{c}-3.21 \\
-- \\
-- \\
-3.42\end{array}$ & $\begin{array}{l}-6.59 \\
-- \\
-- \\
-7.00\end{array}$ & $\begin{array}{r}0.164 \\
.158 \\
.134 \\
.137\end{array}$ & $\begin{array}{l}-7.51 \\
-8.52 \\
-9.09 \\
-8.09\end{array}$ & $\begin{array}{l}-0.845 \\
-1.87 \\
-2.35 \\
-1.27\end{array}$ \\
\hline
\end{tabular}


Table 25.--Saturation indices of selected minerals in water from wells completed in or near spoil--Continued

\section{We11}

number Date

(figs. of

2-4) sample Alunite Albite Adualria Kaolinite
Amorphous

ferric

hydroxide Pyrite Siderite

\begin{tabular}{|c|c|c|c|c|c|c|c|c|}
\hline 1 & $\begin{array}{r}7-21-81 \\
12-8-81 \\
3-24-82 \\
6-7-82 \\
9-1-82\end{array}$ & $\begin{array}{l}-\overline{-} \\
0.543 \\
1.11 \\
2.96 \\
--\end{array}$ & $\begin{array}{c}-.- \\
-2.62 \\
-2.10 \\
-2.12 \\
--\end{array}$ & $\begin{array}{l}-- \\
-1.18 \\
-.664 \\
-.669 \\
--\end{array}$ & $\begin{array}{c}-- \\
1.89 \\
2.59 \\
3.24 \\
--\end{array}$ & $\begin{array}{c}-- \\
-1.58 \\
-1.22 \\
-.872 \\
--\end{array}$ & $\begin{array}{l}-3.60 \\
10.7 \\
10.8 \\
10.4 \\
10.6\end{array}$ & $\begin{array}{r}0.565 \\
.332 \\
.435 \\
.237 \\
.427\end{array}$ \\
\hline 2 & $\begin{array}{r}12-8-81 \\
3-24-82 \\
6-7-82 \\
9-1-82\end{array}$ & $\begin{array}{c}2.14 \\
2.00 \\
.513 \\
--\end{array}$ & $\begin{array}{c}-1.89 \\
-1.69 \\
-2.58 \\
--\end{array}$ & $\begin{array}{c}-0.563 \\
-.536 \\
-1.41 \\
--\end{array}$ & $\begin{array}{c}3.17 \\
3.43 \\
2.11 \\
-.\end{array}$ & $\begin{array}{c}-1.08 \\
-.976 \\
-1.58 \\
--\end{array}$ & $\begin{array}{c}9.51 \\
10.1 \\
9.80 \\
10.1\end{array}$ & $\begin{array}{r}-0.333 \\
-.126 \\
-.202 \\
.156\end{array}$ \\
\hline 3 & $\begin{array}{r}7-20-81 \\
12-9-81 \\
3-26-82 \\
6-7-82 \\
8-31-82 \\
7-26-83\end{array}$ & $\begin{array}{c}7.45 \\
1.85 \\
4.35 \\
-- \\
.940 \\
1.41\end{array}$ & $\begin{array}{c}-1.79 \\
-1.64 \\
-.886 \\
-- \\
2.69 \\
-1.70\end{array}$ & $\begin{array}{c}0.400 \\
-.339 \\
.284 \\
-- \\
-1.67 \\
-.619\end{array}$ & $\begin{array}{c}6.07 \\
3.00 \\
4.65 \\
-- \\
1.71 \\
2.84\end{array}$ & $\begin{array}{c}0.680 \\
-1.15 \\
-.309 \\
-- \\
-1.64 \\
-1.10\end{array}$ & $\begin{array}{c}9.60 \\
10.2 \\
10.0 \\
9.34 \\
9.53 \\
9.91\end{array}$ & $\begin{array}{r}-0.399 \\
.010 \\
-.351 \\
-.508 \\
-.363 \\
.024\end{array}$ \\
\hline 4 & $\begin{array}{r}12-9-81 \\
3-24-82 \\
6-7-82 \\
9-1-82\end{array}$ & $\begin{array}{l}5.17 \\
3.80 \\
3.45 \\
.988\end{array}$ & $\begin{array}{l}-0.769 \\
-1.31 \\
-1.52 \\
-2.03\end{array}$ & $\begin{array}{l}0.487 \\
-.247 \\
-.389 \\
-.942\end{array}$ & $\begin{array}{l}5.20 \\
4.20 \\
3.91 \\
2.66\end{array}$ & $\begin{array}{r}-0.059 \\
-.536 \\
-.628 \\
-1.24\end{array}$ & $\begin{array}{c}9.64 \\
10.1 \\
9.09 \\
9.87\end{array}$ & $\begin{array}{r}-0.712 \\
-.130 \\
-.279 \\
-.307\end{array}$ \\
\hline 6 & $\begin{array}{r}7-21-81 \\
3-25-82 \\
6-8-82 \\
9-2-82\end{array}$ & $\begin{array}{l}-\overline{-} \\
2.91 \\
3.01 \\
1.75\end{array}$ & $\begin{array}{l}-- \\
-0.720 \\
-1.27 \\
-1.41\end{array}$ & $\begin{array}{l}-. \\
0.513 \\
-.078 \\
-.353\end{array}$ & $\begin{array}{l}-- \\
3.87 \\
3.36 \\
2.83\end{array}$ & $\begin{array}{r}-- \\
-0.581 \\
-.693 \\
-.945\end{array}$ & $\begin{array}{l}11.0 \\
12.5 \\
12.1 \\
12.0\end{array}$ & $\begin{array}{l}1.30 \\
2.45 \\
2.13 \\
2.12\end{array}$ \\
\hline 7 & $\begin{array}{r}7-21-81 \\
12-9-81 \\
3-25-82 \\
6-8-82 \\
9-2-82\end{array}$ & $\begin{array}{l}7.62 \\
3.29 \\
2.85 \\
2.72 \\
.930\end{array}$ & $\begin{array}{l}-1.28 \\
-2.88 \\
-2.60 \\
-2.83 \\
-3.55\end{array}$ & $\begin{array}{c}1.10 \\
-.934 \\
-.669 \\
-.888 \\
-1.53\end{array}$ & $\begin{array}{l}6.44 \\
2.71 \\
3.04 \\
2.84 \\
1.72\end{array}$ & $\begin{array}{r}0.820 \\
-1.13 \\
-.927 \\
-.870 \\
-1.46\end{array}$ & $\begin{array}{l}10.8 \\
11.0 \\
12.0 \\
11.7 \\
11.2\end{array}$ & $\begin{array}{r}0.750 \\
.385 \\
1.39 \\
1.43 \\
.872\end{array}$ \\
\hline 8 & $\begin{array}{r}7-21-81 \\
12-9-81 \\
3-25-82 \\
6-8-82 \\
9-2-82 \\
7-26-83\end{array}$ & $\begin{array}{l}1.63 \\
4.13 \\
1.89 \\
2.86 \\
1.26 \\
.900\end{array}$ & $\begin{array}{l}-2.03 \\
-.384 \\
-.941 \\
-1.10 \\
-1.46 \\
-2.00\end{array}$ & $\begin{array}{r}0.862 \\
.641 \\
.071 \\
-.117 \\
-.413 \\
-.984\end{array}$ & $\begin{array}{l}2.60 \\
4.91 \\
3.86 \\
4.01 \\
3.12 \\
2.44\end{array}$ & $\begin{array}{r}-1.12 \\
-.240 \\
-.591 \\
-.491 \\
-.999 \\
-1.29\end{array}$ & $\begin{array}{c}8.75 \\
9.80 \\
9.95 \\
9.98 \\
10.1 \\
10.1\end{array}$ & $\begin{array}{r}-1.38 \\
-.060 \\
-.062 \\
.098 \\
-.002 \\
.075\end{array}$ \\
\hline
\end{tabular}


Table 25.--Saturation indices of selected minerals in water from wells completed in or near spoil--Continued

\begin{tabular}{|c|c|c|c|c|c|c|c|c|}
\hline $\begin{array}{l}\text { WelT } \\
\text { number } \\
\text { (figs. } \\
2-4 \text { ) }\end{array}$ & $\begin{array}{c}r \text { Date } \\
\text { - of } \\
\text { sample }\end{array}$ & Alunite & Albite & Adualria & Kaol inite & $\begin{array}{c}\text { Amorphous } \\
\text { ferric } \\
\text { hydroxide }\end{array}$ & Pyrite & Siderite \\
\hline 9 & $\begin{array}{r}12-9-81 \\
3-25-82 \\
6-8-82 \\
9-1-82\end{array}$ & $\begin{array}{c}0.161 \\
2.81 \\
.613 \\
-.079\end{array}$ & $\begin{array}{r}-3.19 \\
1.90 \\
-4.25 \\
-4.22\end{array}$ & $\begin{array}{l}-1.55 \\
-.220 \\
-2.52 \\
-2.53\end{array}$ & $\begin{array}{l}1.75 \\
3.99 \\
.994 \\
.778\end{array}$ & $\begin{array}{l}-1.59 \\
-.308 \\
-1.80 \\
-1.89\end{array}$ & $\begin{array}{l}11.0 \\
9.76 \\
9.77 \\
9.99\end{array}$ & $\begin{array}{l}0.604 \\
-.342 \\
-.357 \\
-.040\end{array}$ \\
\hline 10 & $\begin{array}{r}3-25-82 \\
6-8-82 \\
9-1-82\end{array}$ & $\begin{array}{r}2.65 \\
1.57 \\
-2.03\end{array}$ & $\begin{array}{l}-4.90 \\
-3.51 \\
-4.76\end{array}$ & $\begin{array}{l}-3.00 \\
-1.82 \\
-3.11\end{array}$ & $\begin{array}{l}2.06 \\
2.44 \\
-.058\end{array}$ & $\begin{array}{l}-0.476 \\
-1.14 \\
-2.35\end{array}$ & $\begin{array}{l}9.25 \\
9.03 \\
9.04\end{array}$ & $\begin{array}{l}-1.27 \\
-1.35 \\
-1.10\end{array}$ \\
\hline 11 & $7-21-81$ & 7.78 & 0.350 & 1.43 & 7.03 & 1.30 & 9.90 & -2.44 \\
\hline 12 & $\begin{array}{r}7-21-82 \\
3-25-82 \\
6-8-82 \\
9-1-82 \\
7-25-83\end{array}$ & $\begin{array}{c}7.82 \\
3.02 \\
3.27 \\
-- \\
1.38\end{array}$ & $\begin{array}{c}-0.629 \\
-.417 \\
-1.24 \\
-- \\
-2.02\end{array}$ & $\begin{array}{c}1.40 \\
.620 \\
-.187 \\
-- \\
-.831\end{array}$ & $\begin{array}{c}6.68 \\
4.21 \\
3.83 \\
--- \\
2.54\end{array}$ & $\begin{array}{c}1.03 \\
-.342 \\
.331 \\
-- \\
-.934\end{array}$ & $\begin{array}{l}10.0 \\
10.7 \\
10.0 \\
9.75 \\
9.34\end{array}$ & $\begin{array}{c}0.081 \\
.493 \\
-.0812 \\
.334 \\
-.489\end{array}$ \\
\hline 13 & $\begin{array}{r}3-25-82 \\
6-8-82 \\
9-1-82\end{array}$ & $\begin{array}{l}3.15 \\
3.59 \\
1.54\end{array}$ & $\begin{array}{l}-0.604 \\
-1.05 \\
-2.24\end{array}$ & $\begin{array}{r}0.843 \\
.296 \\
-.901\end{array}$ & $\begin{array}{c}4.61 \\
-- \\
2.51\end{array}$ & $\begin{array}{r}-0.185 \\
-.041 \\
-.920\end{array}$ & $\begin{array}{l}9.86 \\
9.24 \\
9.24\end{array}$ & $\begin{array}{r}-0.607 \\
-.902 \\
-.971\end{array}$ \\
\hline 14 & $\begin{array}{r}12-9-81 \\
3-25-82 \\
6-8-82 \\
9-2-82\end{array}$ & $\begin{array}{l}2.78 \\
.261 \\
2.31 \\
.070\end{array}$ & $\begin{array}{l}-2.60 \\
-4.85 \\
-3.98 \\
-4.29\end{array}$ & $\begin{array}{l}-0.575 \\
-3.01 \\
-2.10 \\
-2.41\end{array}$ & $\begin{array}{c}3.08 \\
.131 \\
1.68 \\
.567\end{array}$ & $\begin{array}{l}-0.950 \\
-2.67 \\
-1.72 \\
-2.26\end{array}$ & $\begin{array}{c}11.2 \\
9.48 \\
9.87 \\
10.3\end{array}$ & $\begin{array}{l}0.809 \\
-1.75 \\
-.741 \\
-.102\end{array}$ \\
\hline 15 & $\begin{array}{r}12-9-81 \\
3-25-82 \\
6-8-82 \\
9-2-82\end{array}$ & $\begin{array}{l}7.00 \\
4.38 \\
3.85 \\
7.34\end{array}$ & $\begin{array}{l}-4.19 \\
-6.09 \\
-6.97 \\
-4.63\end{array}$ & $\begin{array}{l}-2.21 \\
-4.21 \\
-5.03 \\
-2.71\end{array}$ & $\begin{array}{l}3.27 \\
.488 \\
-.385 \\
3.04\end{array}$ & $\begin{array}{l}-1.00 \\
-2.42 \\
-2.73 \\
-.938\end{array}$ & $\begin{array}{l}8.74 \\
7.90 \\
7.26 \\
8.01\end{array}$ & $\begin{array}{c}-2.54 \\
-- \\
-- \\
-3.01\end{array}$ \\
\hline
\end{tabular}


Table 25.--Saturation indices of selected minerals in water from wells completed in or near spoil--Continued

\begin{tabular}{|c|c|c|c|c|}
\hline $\begin{array}{c}\text { Well } \\
\text { number } \\
\text { (figs.2-4) }\end{array}$ & $\begin{array}{c}\text { Date } \\
\text { of } \\
\text { sample }\end{array}$ & Quartz & Illite & $\begin{array}{l}\text { Calcium } \\
\text { montmor- } \\
\text { rillonite }\end{array}$ \\
\hline 1 & $\begin{array}{r}7-21-81 \\
12-8-81 \\
3-24-82 \\
6-7-82 \\
9-1-82\end{array}$ & $\begin{array}{r}0.571 \\
.578 \\
.595 \\
.579 \\
.579\end{array}$ & $\begin{array}{c}-- \\
-0.077 \\
.906 \\
1.33 \\
--\end{array}$ & $\begin{array}{l}-- \\
1.15 \\
2.07 \\
2.73 \\
--\end{array}$ \\
\hline 2 & $\begin{array}{r}12-8-81 \\
3-24-82 \\
6-7-82 \\
9-1-82\end{array}$ & $\begin{array}{r}0.720 \\
.743 \\
.715 \\
.707\end{array}$ & $\begin{array}{l}1.36 \\
1.67 \\
-.037 \\
-.\end{array}$ & $\begin{array}{l}2.77 \\
3.16 \\
1.58 \\
--\end{array}$ \\
\hline 3 & $\begin{array}{r}7-20-81 \\
12-9-81 \\
3-26-82 \\
6-7-82 \\
8-31-82 \\
7-26-83\end{array}$ & $\begin{array}{r}0.446 \\
.690 \\
.662 \\
.633 \\
.582 \\
.608\end{array}$ & $\begin{array}{c}4.43 \\
1.45 \\
3.20 \\
-. \\
-.567 \\
1.23\end{array}$ & $\begin{array}{c}5.86 \\
2.60 \\
4.46 \\
-. \\
.924 \\
2.41\end{array}$ \\
\hline 4 & $\begin{array}{r}12-9-81 \\
3-24-82 \\
6-7-82 \\
9-1-82\end{array}$ & $\begin{array}{c}0.698 \\
.681 \\
.663 \\
.647\end{array}$ & $\begin{array}{l}3.73 \\
2.41 \\
2.08 \\
.785\end{array}$ & $\begin{array}{l}5.13 \\
3.93 \\
3.62 \\
2.20\end{array}$ \\
\hline 6 & $\begin{array}{r}7-21-81 \\
3-25-82 \\
6-8-82 \\
9-2-82\end{array}$ & $\begin{array}{r}0.540 \\
.577 \\
.461 \\
.452\end{array}$ & $\begin{array}{l}2 . \overline{-} \\
2.07 \\
1.51\end{array}$ & $\begin{array}{l}3 .- \\
3.60 \\
2.84 \\
2.25\end{array}$ \\
\hline 7 & $\begin{array}{r}7-21-81 \\
12-9-81 \\
3-25-82 \\
6-8-82 \\
9-2-82\end{array}$ & $\begin{array}{r}0.499 \\
.517 \\
.493 \\
.378 \\
.393\end{array}$ & $\begin{array}{l}5.30 \\
.549 \\
1.26 \\
1.03 \\
-.337\end{array}$ & $\begin{array}{l}6.44 \\
1.90 \\
2.36 \\
2.07 \\
.755\end{array}$ \\
\hline 8 & $\begin{array}{r}7-21-81 \\
12-9-81 \\
3-25-82 \\
6-8-82 \\
9-2-82 \\
7-26-83\end{array}$ & $\begin{array}{r}0.513 \\
.731 \\
.596 \\
.599 \\
.631 \\
.598\end{array}$ & $\begin{array}{l}0.787 \\
3.67 \\
2.60 \\
2.52 \\
1.62 \\
.584\end{array}$ & $\begin{array}{l}1.96 \\
4.89 \\
3.64 \\
3.79 \\
2.76 \\
1.89\end{array}$ \\
\hline
\end{tabular}


Table 25.--Saturation indices of selected minerals in water from wells completed in or near spoil--Continued

\begin{tabular}{|c|c|c|c|c|}
\hline $\begin{array}{c}\text { Wel1 } \\
\text { number } \\
\text { (figs.2-4) }\end{array}$ & $\begin{array}{c}\text { Date } \\
\text { of } \\
\text { sample }\end{array}$ & Quartz & Illite & $\begin{array}{l}\text { Calcium } \\
\text { montmor- } \\
\text { rillonite }\end{array}$ \\
\hline 9 & $\begin{array}{r}12-9-81 \\
3-25-82 \\
6-8-82 \\
9-1-82\end{array}$ & $\begin{array}{r}0.521 \\
.377 \\
.374 \\
.371\end{array}$ & $\begin{array}{l}-0.330 \\
2.68 \\
-1.64 \\
-1.76\end{array}$ & $\begin{array}{l}0.922 \\
3.54 \\
-.205 \\
-.406\end{array}$ \\
\hline 10 & $\begin{array}{r}3-25-82 \\
6-8-82 \\
9-1-82\end{array}$ & $\begin{array}{r}-0.444 \\
.434 \\
.423\end{array}$ & $\begin{array}{c}-0.760 \\
.061 \\
-2.85\end{array}$ & $\begin{array}{c}0.107 \\
1.62 \\
-1.28\end{array}$ \\
\hline 11 & $7-21-81$ & 0.300 & 6.08 & 6.91 \\
\hline 12 & $\begin{array}{r}7-21-81 \\
3-25-82 \\
6-8-82 \\
9-1-82 \\
7-25-83\end{array}$ & $\begin{array}{r}0.400 \\
.493 \\
.327 \\
.311 \\
.297\end{array}$ & $\begin{array}{c}5.73 \\
3.30 \\
2.38 \\
-- \\
.914\end{array}$ & $\begin{array}{c}6.62 \\
3.88 \\
3.20 \\
-- \\
1.68\end{array}$ \\
\hline 13 & $\begin{array}{r}3-25-82 \\
6-8-82 \\
9-1-82\end{array}$ & $\begin{array}{r}0.392 \\
.300 \\
.260\end{array}$ & $\begin{array}{l}3.80 \\
3.19 \\
.801\end{array}$ & $\begin{array}{l}4.25 \\
3.84 \\
1.57\end{array}$ \\
\hline 14 & $\begin{array}{r}12-9-81 \\
3-25-82 \\
6-8-82 \\
9-2-82\end{array}$ & $\begin{array}{c}0.568 \\
.781 \\
.640 \\
.631\end{array}$ & $\begin{array}{r}1.33 \\
-3.15 \\
-1.12 \\
-2.15\end{array}$ & $\begin{array}{l}2.53 \\
-.977 \\
.785 \\
-.446\end{array}$ \\
\hline 15 & $\begin{array}{r}12-9-81 \\
3-25-82 \\
6-8-82 \\
9-2-82\end{array}$ & $\begin{array}{r}0.696 \\
.727 \\
.614 \\
.556\end{array}$ & $\begin{array}{l}-0.273 \\
-4.11 \\
-5.44 \\
-.802\end{array}$ & $\begin{array}{c}2.39 \\
-.999 \\
-2.19 \\
1.96\end{array}$ \\
\hline
\end{tabular}

